SHEILA REGINA MAIA BRAGA

\title{
COMPARAÇÃO DO POTENCIAL EROSIVO DE DUAS FONTES ÁCIDAS SOBRE O ESMALTE E AVALIAÇÃO DE MÉTODOS DE CONTROLE DA EROSÃO DENTAL
}




\section{Sheila Regina Maia Braga}

Comparação do potencial erosivo de duas fontes ácidas sobre o esmalte e avaliação de métodos de controle da erosão dental

Tese apresentada à Faculdade de Odontologia da Universidade de São Paulo, para obter o título de Doutor, pelo Programa de Pós-Graduação em Odontologia.

Área de Concentração: Dentística

Orientador: Profa. Dra. Maria Angela Pita Sobral

São Paulo 
Catalogação-na-Publicação

Serviço de Documentação Odontológica

Faculdade de Odontologia da Universidade de São Paulo

Braga, Sheila Regina Maia

Comparação do potencial erosivo de duas fontes ácidas sobre o esmalte e avaliação de métodos de controle da erosão dental / Sheila Regina Maia Braga; orientador Maria Angela Pita Sobral. -- São Paulo, 2009.

126p. : fig., tab.; $30 \mathrm{~cm}$.

Tese (Doutorado - Programa de Pós-Graduação em Odontologia. Área de Concentração: Dentística) -- Faculdade de Odontologia da Universidade de São Paulo.

1. Erosão de dente - Esmalte - Controle 2. Dentística

CDD 617.675

BLACK D2

AUTORIZO A REPRODUÇÃO E DIVULGAÇÃO TOTAL OU PARCIAL DESTE TRABALHO, POR QUALQUER MEIO CONVENCIONAL OU ELETRÔNICO, PARA FINS DE ESTUDO E PESQUISA, DESDE QUE CITADA A FONTE E COMUNICADA AO AUTOR A REFERÊNCIA DA CITAÇÃO.

São Paulo,

Assinatura:

E-mail: 


\section{FOLHA DE APROVAÇÃO}

Braga SRM. Comparação do potencial erosivo de duas fontes ácidas sobre o esmalte e avaliação de métodos de controle da erosão dental [Tese de Doutorado]. São Paulo: Faculdade de Odontologia da USP; 2009.

São Paulo, / 2009

\section{Banca Examinadora}

1) $\operatorname{Prof}(a) . \operatorname{Dr}(a)$.

Titulação:

Julgamento:

Assinatura:

2) $\operatorname{Prof}(a) . \operatorname{Dr}(a)$.

Titulação:

Julgamento:

Assinatura:

3) $\operatorname{Prof}(a) . \operatorname{Dr}(a)$.

Titulação:

Julgamento:

Assinatura:

4) $\operatorname{Prof}(a) . \operatorname{Dr}(a)$.

Titulação:

Julgamento:

Assinatura:

5) $\operatorname{Prof}(a) . \operatorname{Dr}(a)$.

Titulação:

Julgamento:

Assinatura: 


\section{AGRADECIMENTO ESPECIAL}

\section{À Deus}

Tão misericordioso é D eus, que nos dá oportunidade de corrigir os erros,

Começar de novo, fazer o dia de hoje melhor que o dia de ontem.

M áxima oriental

À minha famíla

Paz e harmonia - esta é a verdadeira riqueza de uma família

B enjamin F ranklin

À Profa. Dra. Maria Angela Pita Sobral

$F$ eliz aquele que transfere 0 que sabe e aprende 0 que ensina

Pensador anônimo

Somente com a ajuda de vocês foi possível concluir este trabalho. O brigada!!! 


\section{AGRADECIMENTOS}

À Profa. Dra. Elisabeth de Oliveira, pelas análises de Espectrometria de Emissão Atômica.

À Profa. Dra. Dalva Lúcia de Araújo Faria, pelas análises de Espectroscopia FTRaman e orientação na interpretação dos resultados.

Aos professores e funcionários do LELO, que disponibilizaram o uso do equipamento de laser.

À equipe do Serviço de Endoscopia do Hospital Universitário (HU): Dr. Luis Masúo Maruto, chefe do serviço, que permitiu a realização da pesquisa em seu departamento; Dr. José Guilherme da Silva que foi meu tutor perante a Comissão de Ética do hospital, demais médicos, enfermeiras e técnicas em enfermagem que possibilitaram a execução da coleta do suco gástrico.

Aos colegas de pós-graduação, pelo enriquecedor convívio.

À CAPES pela bolsa de estudos.

A todos os funcionários do Departamento de Dentística, em especial a técnica Sônia pela sua presteza.

Às bibliotecárias, pela rapidez em executar a revisão final deste trabalho. 


\section{SER J OVEM}

$\mathrm{N}$ ão é por termos vivido um certo número de anos que envelhecemos, envelhecemos porque abandonamos o nosso ideal.

Os anos en rugam o rosto, renunciar ao ideal enruga a alma.

As preocupações, as dúvidas, os temores e os desesperos são os inimigos que lentamente nos inclinam para a terra e nos tornam pó antes da morte.

Jovem é aquele que admira, que se maravilha e pergunta como a criança insaciável: $E$ depois?...

Que desafia os acontecimentos e encontra alegria no jogo da vida.

És tão jovem quanto a tua fé.

Tão velho quanto a tua descrença.

Tão jovem quanto a tua confiança em ti e a tua esperança.

Tão velho quanto o teu desânimo.

Serás jovem enquanto te conservares receptivo ao que é belo, bom, grande.

Receptivo às mensagens da natureza, do homem, do infinito.

E se um dia teu coração for atacado pelo pessimismo e corroído pelo cinismo, que D eus então se compadeça de tua alma de velho. 
Braga SRM. Comparação do potencial erosivo de duas fontes ácidas sobre o esmalte e avaliação de métodos de controle da erosão dental [Tese de Doutorado].

São Paulo: Faculdade de Odontologia da USP; 2009.

\section{RESUMO}

Erosão dental é definida como a perda irreversível de tecido duro dental por um processo químico que não envolve bactérias. O objetivo deste trabalho foi comparar in vitro o potencial erosivo de duas fontes ácidas e avaliar métodos de controle da erosão dental em esmalte. Para a comparação das fontes ácidas, coroas de 5 molares inclusos foram seccionadas em quatro, totalizando 20 espécimes. Nos espécimes, uma superfície de esmalte (janela) de $3 \times 3 \mathrm{~mm}$ foi delimitada. Os espécimes foram submetidos ao desafio erosivo em suco gástrico (obtido durante endoscopia) ( $n=10)$, ou suco de laranja (industrializado) $(n=10)$, como segue: 5 minutos em $3 \mathrm{ml}$ de solução ácida, enxágue com água destilada e armazenagem em saliva artificial por 3 horas. Este ciclo foi repetido 4 vezes ao dia por 14 dias. O cálcio (Ca) eliminado dos espécimes na solução ácida foi quantificado por Espectrometria de emissão atômica. A presença de carbonato (CO) e fosfato (PO) foi avaliada nos espécimes antes e após o desafio erosivo pela Espectroscopia FT-Raman. Para a avaliação dos métodos de controle da erosão quarenta espécimes de esmalte de molares inclusos foram distribuídos para cada um dos métodos propostos $(n=10)$ : gel de flúor fosfato acidulado (APF 1,23\%), laser de Nd:YAG (100 mJ, $1 \mathrm{~W}, 10 \mathrm{~Hz}$ ), associação flúor + laser e laser + flúor. Os métodos de controle foram aplicados 1 hora antes do desafio erosivo já descrito, realizado com ácido clorídrico $(0,01 \mathrm{M} / \mathrm{pH}$ 2,2) como fonte ácida. O flúor foi mantido por 4 minutos sobre a superfície de esmalte. A superfície foi irradiada, com contato, após aplicação de um fotoabsorvedor. As associações foram feitas utilizando o flúor e o laser como descrito anteriormente. A perda de Ca dos espécimes foi quantificada por Espectrometria de emissão atômica e a rugosidade superficial dos espécimes (Ra) foi avaliada antes e após o desafio erosivo. Na comparação das fontes ácidas, os espécimes submetidos à erosão perderam: 12,74 $\pm 3,33 \mathrm{mg} / \mathrm{L}$ de Ca (suco gástrico) e 7,07 $\pm 1,44 \mathrm{mg} / \mathrm{L}$ de Ca (suco de laranja) ( $p=0,0003)$. A análise em Espectroscopia FT-Raman não 
detectou alteração significativa na razão CO/PO após o desafio ácido. Os valores $\mathrm{CO} / \mathrm{PO}$ antes e depois do desafio foram: 0,16/0,17 (suco gástrico) $(\mathrm{p}=0,37)$ e $0,18 / 0,14$ (suco de laranja) $(p=0,16)$. Na avaliação dos métodos de controle da erosão, as perdas de Ca foram (mg/L): APF 1,707a ( $\pm 0,113)$, Nd:YAG 1,638a $( \pm 0,080), A P F+N d: Y A G 1,385 b( \pm 0,078), N d: Y A G+$ APF 1,484b $( \pm 0,068) . A$ rugosidade média inicial dos espécimes foi de 0,14 $\mu \mathrm{m}$. Após o desafio erosivo a rugosidade apresentou significativo aumento $(p<0,01)$ : APF $0,69 \mathrm{bc} \quad( \pm 0,091)$, $\mathrm{Nd}: Y A G \quad 0,87 a( \pm 0,119)$, APF + Nd:YAG 0,61c $( \pm 0,090)$ e Nd:YAG + APF 0,72b $( \pm 0,069)$. Foi possível concluir que o suco gástrico apresentou potencial erosivo ao esmalte maior que o suco de laranja. A associação entre flúor e laser apresentou-se mais eficaz no controle da erosão dental do que os métodos isoladamente.

Palavras-Chave: Erosão dentária; Flúor; Lasers; Prevenção \& controle; Espectrometria; Análise espectral Raman; Desmineralização do dente 
Braga SRM. Comparison of the erosive potential of two acidic sources in enamel and evaluation of treatments for prevention of dental erosion [Tese de Doutorado]. São Paulo: Faculdade de Odontologia da USP; 2009.

\section{ABSTRACT}

Dental erosion is defined as irreversible loss of dental hard tissue due to chemical processes without the involvement of microorganisms. The aim of this study was to compare in vitro the erosive potential of two acidic sources and evaluate the effectiveness of treatments for prevention of dental erosion. To compare the acidic sources, crowns of 5 unerupted human third molars were sectioned in four, totalizing 20 enamel slabs. In the slabs, a test surface (window) of $3 \times 3 \mathrm{~mm}$ was delimited. The specimens were submitted to erosive challenge into gastric juice (from endoscopy exam) $(n=10)$, or orange juice (industrialized) $(n=10)$, as follows: 5 minutes in $3 \mathrm{ml}$ of acidic solution, rinse with distilled water and stored in artificial saliva for 3 hours. This cycle was repeated for four times a day during 14 days. Calcium (Ca) loss after acid exposure was determined by atomic emission spectroscopy. The presence of carbonate (CO) and phosphate (PO) in the specimens was evaluated before and after the erosive challenge by FT-Raman spectroscopy. To evaluate the treatments for prevention of dental erosion, forty enamel specimens of unerupted human third molars were distributed according to the following treatments $(n=10)$ : acidic phosphate fluoride gel (APF 1.23\%), Nd:YAG laser (100 mJ, $1 \mathrm{~W}, 10 \mathrm{~Hz}$ ), and the associations fluoride + laser and laser + fluoride. These treatments were applied 1 hour before the erosive challenge, which, in this phase was made with hydrochloric acid only $(0.01 \mathrm{M} / \mathrm{pH} 2.2)$. The fluoride was applied on the enamel surfaces for 4 minutes. The irradiation of enamel surface was made in the contact mode after coating with a photo-activator. The associations were done using fluoride and laser like describe before. The Ca loss was determined by atomic emission spectroscopy and superficial roughness $(\mathrm{Ra})$ was measured before and after the erosive challenge. In the comparison of the acidic sources, the mean loss of Ca were: $12.74 \pm 3.33 \mathrm{mg} / \mathrm{L} \mathrm{Ca}$ (gastric juice) and $7.07 \pm 1.44 \mathrm{mg} / \mathrm{L} \mathrm{Ca}$ (orange juice) $(p=0.0003)$. The FT-Raman spectroscopy found no statistically 
significant difference in the ratio CO/PO after the erosive challenge. The CO/PO ratios values before and after the challenge were: $0.16 / 0.17$ (gastric juice) ( $p=0.37$ ) and $0.18 / 0.14$ (orange juice) ( $p=0.16)$. In the evaluation of the treatments, the mean Ca loss were (mg/L): APF 1.707a $( \pm 0.113)$, Nd:YAG 1.638a $( \pm 0.080)$, APF + $\mathrm{Nd}: Y A G$ 1.385b ( \pm 0.078$), \mathrm{Nd}: Y A G+$ APF 1.484b $( \pm 0.068)$. The mean initial roughness of specimens was $0.14 \mu \mathrm{m}$. After the erosive challenge the roughness showed a significant increase $(p<0.01)$ : APF 0.69bc $( \pm 0.091)$, Nd:YAG $0.87 a$ $( \pm 0.119), A P F+N d: Y A G 0.61 c( \pm 0.090)$ and $N d: Y A G+A P F 0.72 b( \pm 0.069)$. It was concluded that gastric juice has higher erosive potential to enamel than orange juice and the association between fluoride and laser was more efficient for the prevention of dental erosion than both methods separately.

Key-works: Tooth erosion; Fluoride; Lasers; Prevention \& control; Spectrometry; Spectrum analysis Raman; Tooth demineralization 


\section{LISTA DE ILUSTRAÇÕES}

Figura 4.1 - Corte do dente e obtenção de quatro fragmentos. 65

Figura 4.2 - Espécimes de esmalte recobertos com esmalte cosmético formando janela de exposição

Figura 4.3 - Frasco "bronquinho" para coleta de suco gástrico. .67

Figura 4.4 - Suco de laranja utilizado como fonte ácida de origem extrínseca........68

Figura 4.5 - Ciclo de desmineralização-remineralização. 70

Figura 4.6 - Aparelhos utilizados para avaliação da perda de conteúdo mineral dos espécimes. A- Espectrômetro de emissão atômica. B- Espectrômetro FT-Raman.

Figura 4.7 - Métodos de controle da erosão utilizados. A- Flúor. B- Laser Nd:YAG.

Figura 4.8 - Rugosímetro 78

Figura 4.9 - Esquema da metodologia da segunda fase do experimento. .79

Figura 5.1 - Gráfico da titulação do suco de laranja e suco gástrico 81

Figura 5.2 - Médias da intensidade dos picos antes e após ciclagem em suco gástrico.

Figura 5.3 - Médias da intensidade dos picos antes e após ciclagem em suco de laranja. 
Figura 5.4 - Fotomicrografias da superfície dos espécimes (1 aumento 400x, 2 aumento 2000x). A Superfície após polimento para início da ciclagem. B Superfície após ciclagem em suco gástrico. C Superfície após

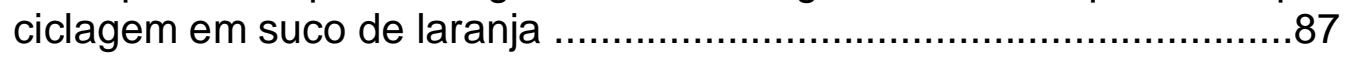

Figura 5.5 - Comparação entre as médias de cálcio perdido dos grupos de métodos de controle da erosão e a análise estatística.

Figura 5.6 - Médias e desvios-padrão da rugosidade superficial antes e após os métodos de controle da erosão e desafio erosivo, análise estatística

Figura 5.7 - Fotomicrografias da superfície dos espécimes (1 aumento 400x, 2 aumento 2000x). A Superfície após aplicação de flúor e desafio ácido. B Superfície após irradiação com laser Nd:YAG e desafio ácido. C Superfície após aplicação de flúor + irradiação com laser de Nd:YAG e desafio ácido. D Superfície após irradiação com laser de Nd:YAG + aplicação de flúor e desafio ácido .93

Quadro 4.1 - Composição da saliva artificial 69 


\section{LISTA DE TABELAS}

Tabela 4.1 - Composição das fontes ácidas avaliadas.

Tabela 4.2 - Distribuição dos espécimes de acordo com o método de controle da erosão.

Tabela 5.1 - Valores de pH do suco de laranja e suco gástrico. .80

Tabela 5.2 - Valores da perda de Ca dos espécimes após ciclagem nas soluções desmineralizantes.

Tabela 5.3 - Média da área sob os picos avaliados antes e após ciclagem em suco gástrico.

Tabela 5.4 - Média da área sob os picos avaliados antes e após ciclagem em suco de laranja.

Tabela 5.5 - Média da razão da área sob os picos estudados com a média da área sob o pico do fosfato (960 $\left.\mathrm{cm}^{-1}, \mathrm{PO}\right)$ antes e após ciclagem em suco gástrico e análise estatística.

Tabela 5.6 - Média da razão da área sob os picos estudados com a média da área sob o pico do fosfato ( $\left.960 \mathrm{~cm}^{-1}, \mathrm{PO}\right)$ antes e após ciclagem em suco de laranja e análise estatística.

Tabela 5.7 - Valores de cálcio perdido pelos espécimes, média, desvio-padrão e erro-padrão dos respectivos grupos de métodos de controle da erosão após desafio ácido.

Tabela 5.8 - Valores de $\mathrm{Ra}(\mu \mathrm{m})$, média, desvio-padrão e erro-padrão dos espécimes antes e após aplicação dos respectivos métodos de controle de erosão e desafio erosivo. 


\section{LISTA DE ABREVIATURA, SIGLAS E SÍMBOLOS}

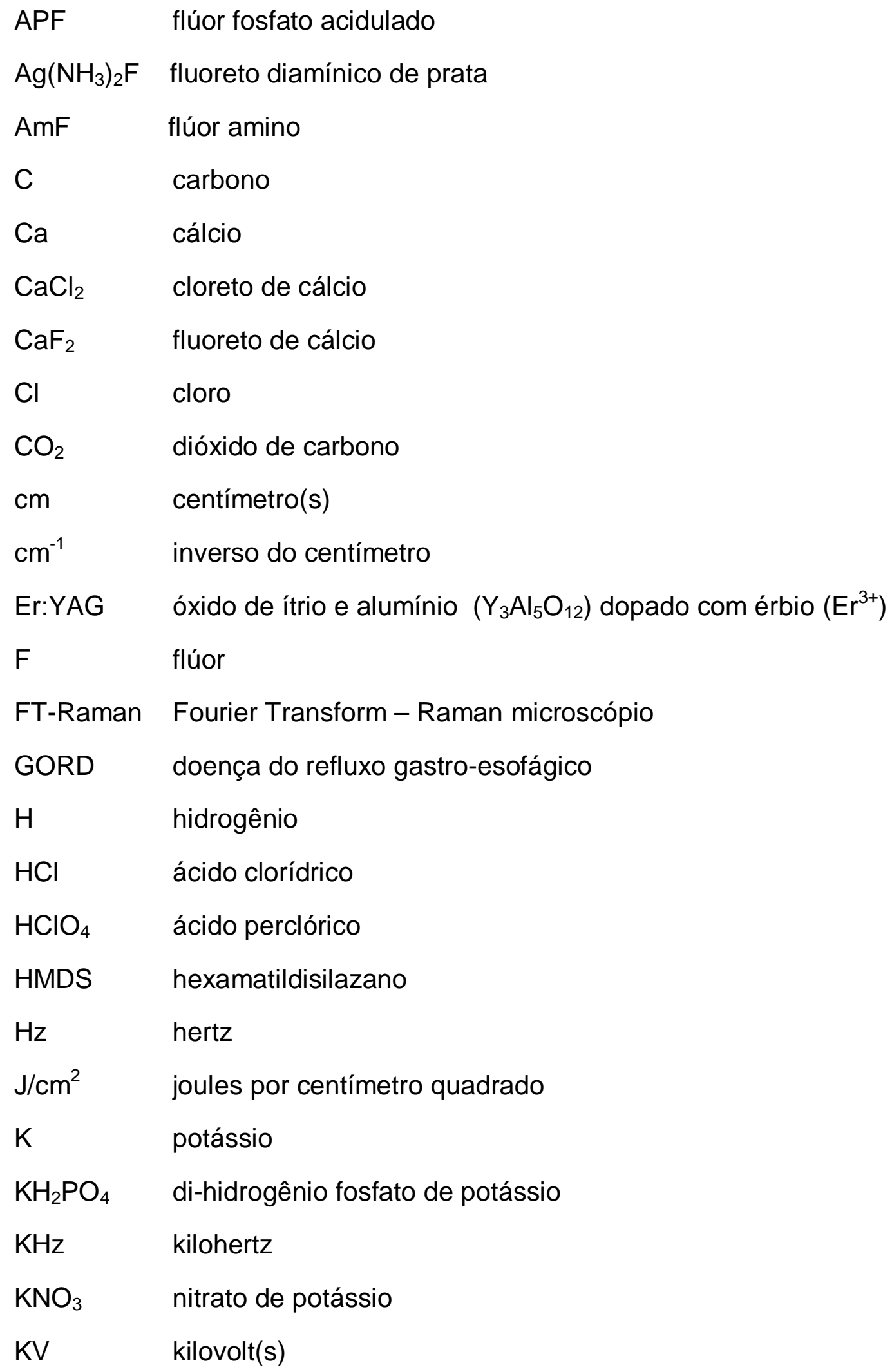




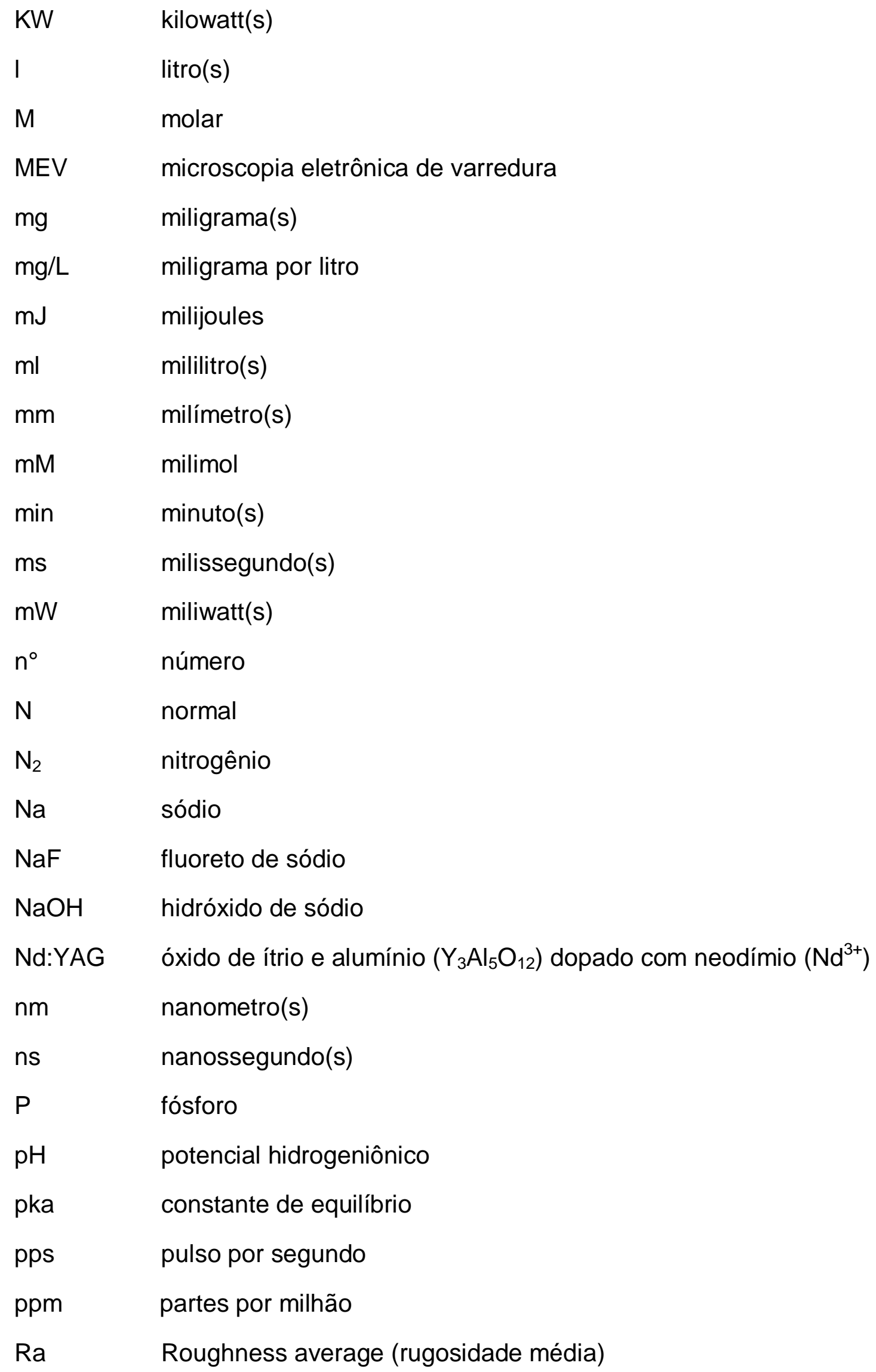




$\begin{array}{ll}\mathrm{S} & \text { segundo(s) } \\ \mathrm{SnCl}_{2} & \text { cloreto de estanho } \\ \mathrm{SnF}_{2} & \text { fluoreto de estanho } \\ \mathrm{TiF}_{4} & \text { fluoreto de titânio } \\ \mu \mathrm{gL}^{-1} & \text { micrograma litro elevado a menos } 1 \\ \mu \mathrm{m} & \text { micrômetro(s) } \\ \mathrm{W} & \text { watt(s) } \\ \AA & \text { angstron } \\ \mathrm{x} & \text { vezes } \\ { }^{\circ} \mathrm{C} & \text { graus Celsius } \\ > & \text { maior } \\ < & \text { menor } \\ \% & \text { porcentagem } \\ \varrho & \text { graus } \\ \Lambda & \text { lâmbda (comprimento de onda) }\end{array}$




\section{SUMÁRIO}

p.

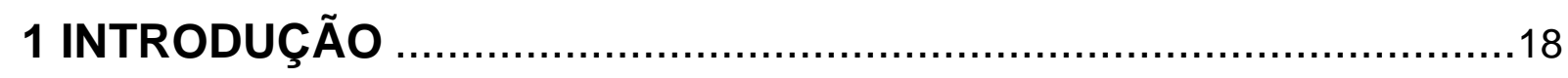

2 REVISÃO DA LITERATURA …...............................................21

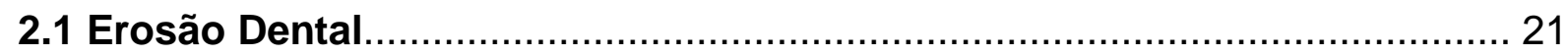

2.1.1 Erosão por ácidos extrínsecos......................................................... 24

2.1.2 Erosão por ácidos intrínsecos......................................................... 31

2.2 Métodos de Controle da Erosão Dental ................................................. 43

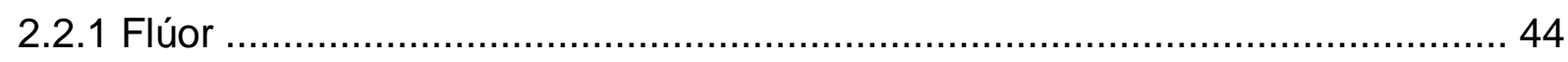

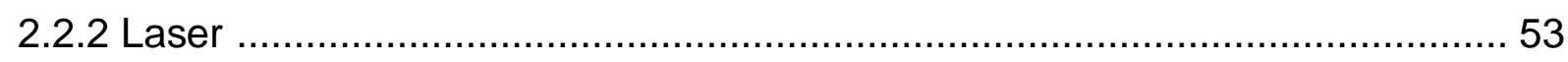

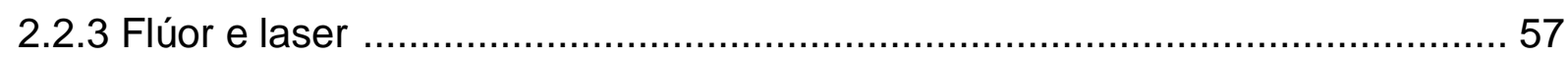

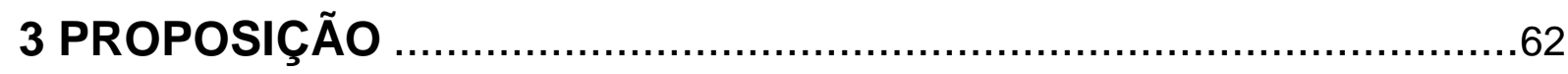

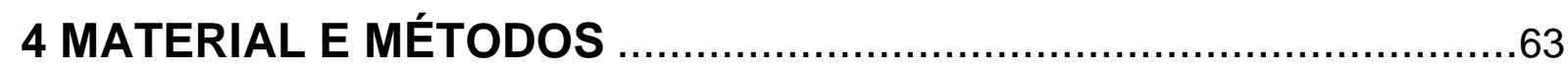

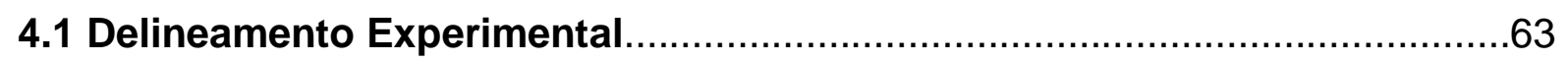

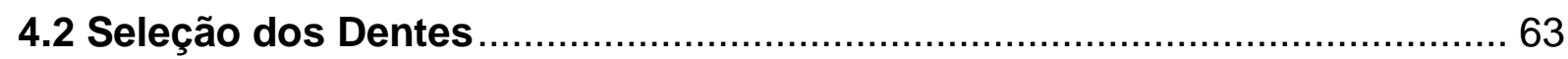

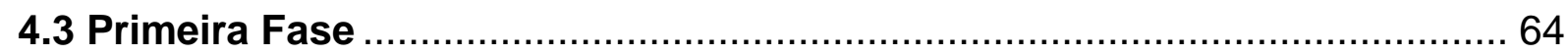

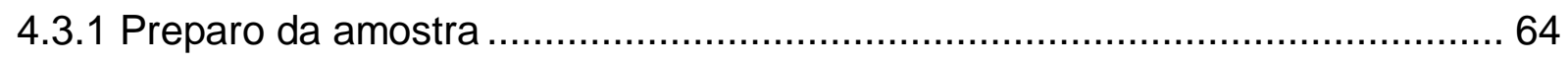

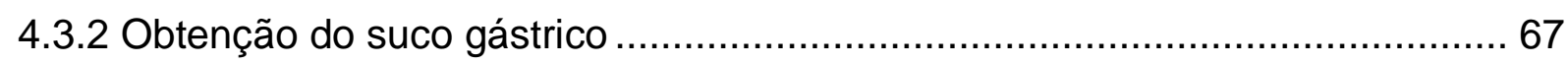

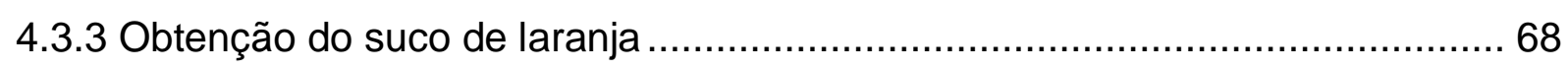

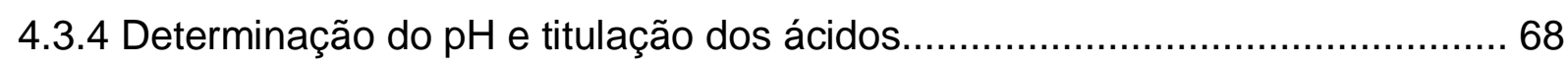

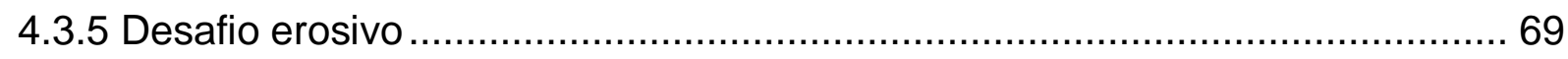

4.3.6 Determinação do potencial erosivo das fontes ácidas ................................ 70

4.3.7 Análise em microscopia eletrônica de varredura ...................................... 73 


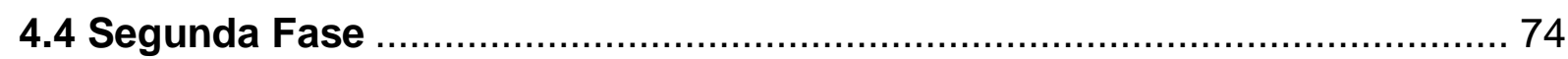

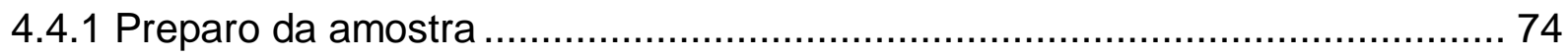

4.4.2 Métodos de controle da erosão .......................................................... 75

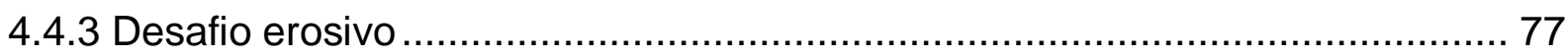

4.4.4 Avaliação dos métodos de controle da erosão ........................................... 77

4.4.5 Análise em microscopia eletrônica de varredura ........................................ 78

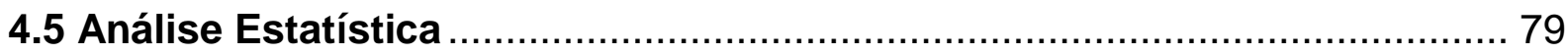

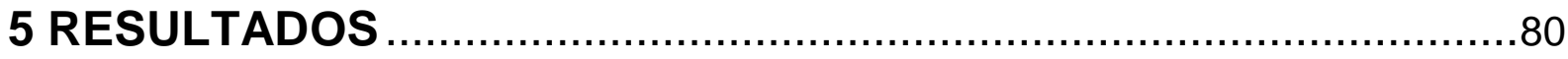

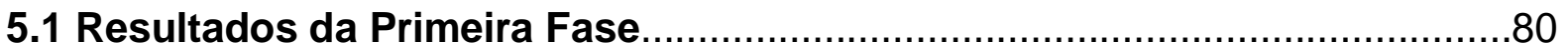

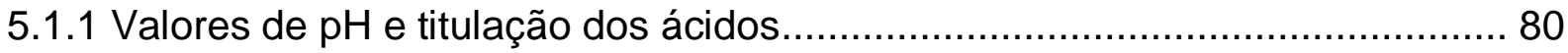

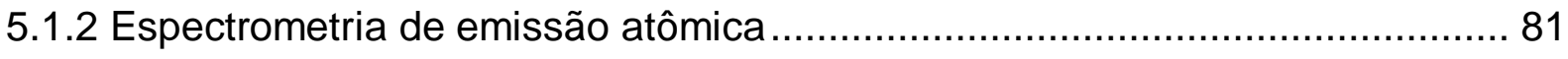

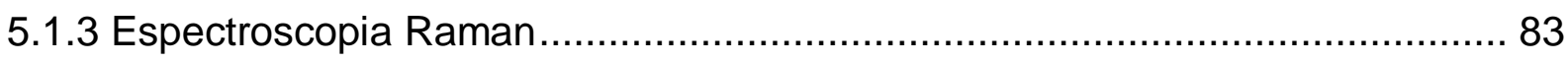

5.1.4 Microscopia eletrônica de varredura......................................................

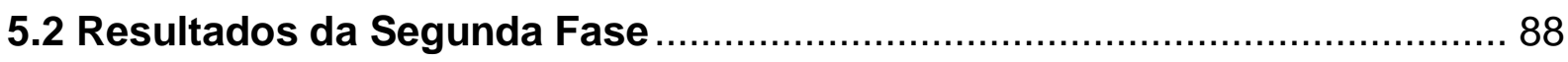

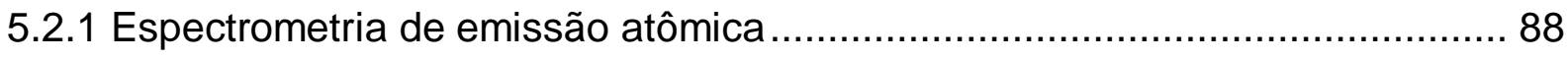

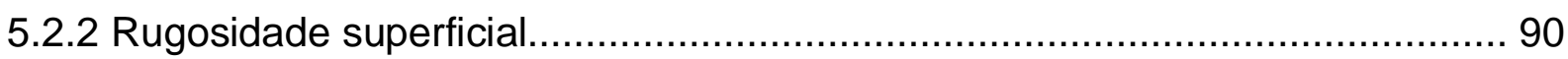

5.2.3 Microscopia eletrônica de varredura ......................................................92

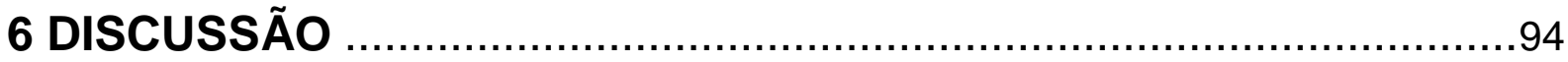

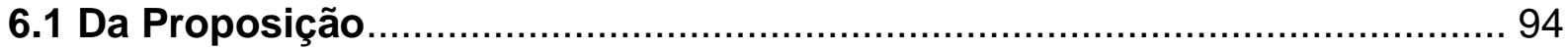

6.2 Dos Materiais e Métodos utilizados ...................................................... 98

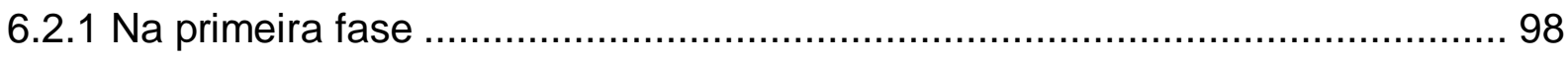

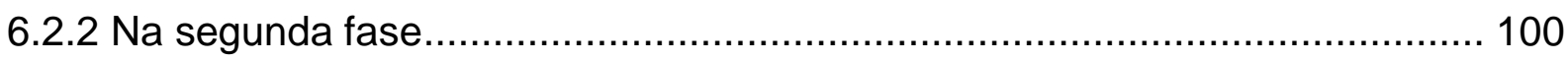

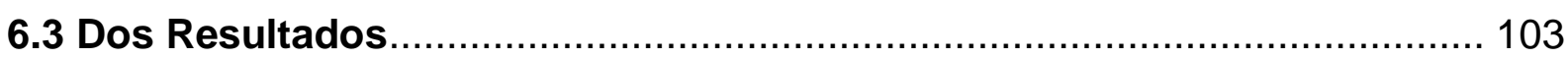

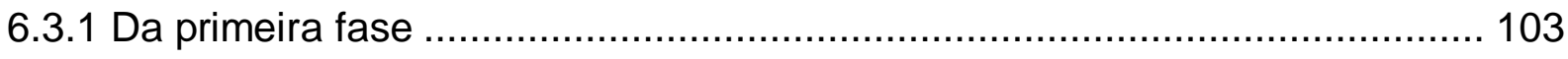

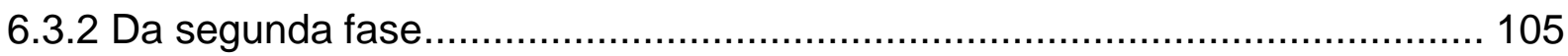

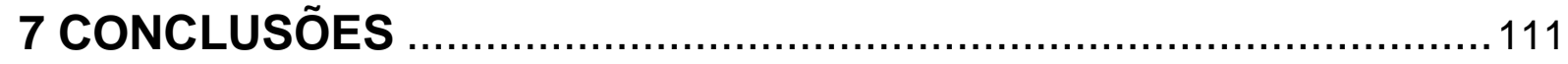

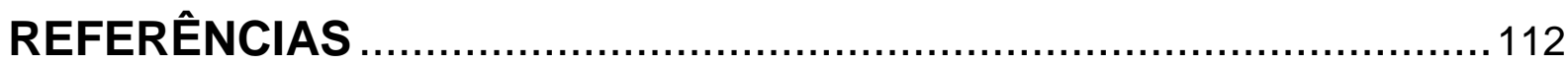

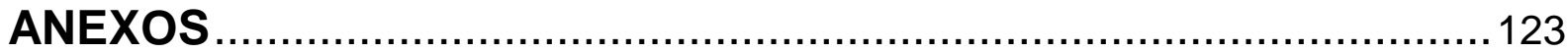




\section{INTRODUÇÃO}

Nos dias atuais, principalmente em centros urbanos desenvolvidos, a incidência da maior doença dental, a cárie, tem declinado (ATTIN; ZIRKEL; HELLWIG, 1998). Entretanto, a manutenção dos dentes, os predispõe a outras lesões dentais, tal como a erosão.

Erosão dental é definida como a perda progressiva de tecido duro dental por um processo químico que não envolve bactérias (AMAECHI; HIGHAM, 2005; DUGMORE; ROCK, 2004; LEVITCH et al., 1994; LUSSI; JAEGGI; JAEGGISCHÄRER, 1995; MEURMAN et al., 1994; OSBORNE-SMITH; BURKE; MANCHESTER, 1999) podendo ocorrer em qualquer superfície do dente.

A erosão dental pode ser causada por fatores extrínsecos e intrínsecos. Agentes extrínsecos incluem bebidas, alimentos, medicação e exposição a ambientes ácidos (BARBOUR; REES, 2004). A erosão causada por ácidos extrínsecos é resultante do efeito, principalmente, dos ácidos orgânicos dos alimentos ou bebidas, tais como suco de frutas, refrigerantes, bebidas esportivas.

A erosão também pode ser causada por fatores intrínsecos, que pode ocorrer se o ácido gástrico alcança a boca devido ao vômito, regurgitação ou na doença do refluxo gastro-esofágico. Vômitos crônicos em pacientes com distúrbios alimentares como anorexia e bulimia nervosa estão relacionados com erosão dental.

Quando o diagnóstico de erosão é feito, existem métodos para controlar a erosão e procedimentos restauradores disponíveis. O primeiro método de controle é a tentativa de remover a fonte de ácido. No caso de ácido extrínseco, o paciente deve ser aconselhado a reduzir o consumo de alimentos e bebidas ácidas. No caso 
de ácidos intrínsecos, o paciente deve ser encaminhado para um médico (PERKINS; WETMORE, 2001). Entretanto, a eliminação do fator causal pode ser difícil, por isso, enquanto as fontes de ácidos não são eliminadas outras medidas devem ser aplicadas para controlar a evolução da erosão dental.

O principal método preventivo ou de controle utilizado para lesões de erosão é a aplicação tópica de flúor. O possível papel do flúor na prevenção da erosão dental pode ser o de fortalecer a superfície do dente e aumentar a resistência à dissolução ácida (BARTLETT, 2005b).

Apesar de muitos autores (GANSS et al., 2004; LAGERWEIJ et al., 2006; WILLUNSEN et al., 2004) reportarem que o flúor age protegendo os dentes contra a erosão, outros autores (LARSEN, 2001; LARSEN; RICHARDS, 2002) dizem que ele não é eficaz. Por isso, tem se buscado novas formas de controlar a atividade erosiva dos ácidos, entre elas o laser (SOBRAL et al., 2009; VLACIC; MEYERS; WALSH, 2007).

Diversos lasers de alta potência podem causar a fusão e recristalização do esmalte, sendo capazes de provocar alterações na permeabilidade e solubilidade do mesmo. Podendo, assim, ser utilizados na prevenção do processo de desmineralização e erosão. O laser de Nd:YAG (neodímio:ítrio-alumínio-granada) vem sendo utilizado na área de prevenção da cárie, uma vez que não remove estrutura dental e pode também ser utilizado na prevenção da erosão.

Uma vez que o flúor e o laser têm apresentado bons resultados na prevenção da desmineralização do esmalte dental, a combinação destes dois elementos pode contribuir para um controle mais efetivo da erosão dental.

Desgaste dental incluindo erosão não é um fenômeno novo, mas tem se intensificado a atenção a ele desde que as cáries têm diminuído em muitas 
sociedades. Para o dentista é importante detectar a principal causa do desgaste dental para implementar métodos adequados para seu controle.

O aumento na longevidade da população e redução na perda de dentes resulta em mais dentes sendo expostos aos efeitos erosivos dos ácidos em períodos maiores de tempo do que no passado. Como resultado a erosão dental por fatores extrínsecos e intrínsecos está crescendo muito entre os pacientes hoje, e pouco se sabe sobre seu controle. Por isso, a necessidade de se estudar a ação dos ácidos sobre os dentes e métodos de controle para minimizar os danos à estrutura dental. 


\section{REVISÃO DA LITERATURA}

A primeira parte desse capítulo enfoca os trabalhos relacionados ao processo de erosão dental, sua etiologia e apresentação. O segundo item dessa revisão, aborda os trabalhos relacionados aos métodos de prevenção ou controle da erosão dental.

Esta divisão visa a uma maior facilidade de apresentação e compreensão dos assuntos abordados neste trabalho.

\subsection{Erosão Dental}

Em um estudo de revisão, Levitch et al. (1994) verificaram que os fatores etiológicos relacionados ao desenvolvimento de lesões cervicais eram: a erosão, abrasão e flexão dental. Definiram a erosão dental como a perda de estrutura devido à ação química de origem não-bacteriana, podendo ser causada por fatores extrínsecos (alimentos e bebidas ácidas, por exemplo) ou intrínsecos (regurgitação em casos de bulimia e anorexia). As lesões podiam aparecer em qualquer região dos dentes; em geral eram em forma de pires, largas, mas pouco profundas.

Nunn (1996) realizou uma revisão de literatura sobre casos clínicos de erosão dental. Considerou difícil comparar os estudos de prevalência, pois os índices utilizados e os dentes avaliados eram diferentes. Os casos clínicos estavam frequentemente associados com excesso de consumo de bebidas e alimentos 
ácidos. O autor ressalta que a equipe odontológica deve estar atenta e deve instituir medidas de controle antes que a perda de tecido se torne clinicamente significante.

ten Cate e Imfeld (1996) estudaram os diferentes aspectos da prevalência, patologia, etiologia, prevenção e tratamento da erosão dental. Afirmaram que a erosão dental sempre foi relatada na literatura, mas que há um crescente interesse entre pesquisadores e clínicos. Os fatores de risco para erosão dental estão relacionados ao estilo de vida e padrão de alimentação, como aumento do consumo de alimentos ácidos. Vários problemas gastro-intestinais e desordens alimentares expõem a dentição ao frequente contato com o conteúdo gástrico muito ácido, o qual pode levar a erosão.

Holbrook, Armadottir e Kay (2003) ao revisarem a literatura em relação ao desgaste dental, observaram que há um considerável aumento na incidência de desgaste dental nos anos recentes e que a erosão tem predominado como causa deste desgaste dental sendo acentuada por outras formas de desgaste.

Na sociedade moderna, tem aumentado o consumo de alimentos ácidos, consequentemente a erosão dental tem sido causa frequente de desgaste dental. A erosão pode resultar do consumo de bebidas e alimentos ácidos e pode ser exacerbada pela xerostomia e incorreta escovação dental. A superfície dental afetada apresenta-se arredondada e brilhante e pode tornar-se hipersensível. A localização do dente afetado depende de como o agente erosivo é consumido (YIP; SMALES; KAIDONIS, 2003).

Bartlett (2005a) avaliou o papel da erosão no desgaste dental e verificou que nos países europeus o papel da erosão ácida tem sido reconhecido como sendo o componente mais importante no desgaste dental, visto que em outros países a atrição é ainda considerada como a causa predominante. A erosão pode ser 
causada por ácidos originários da dieta ou ácido gástrico. $O$ ácido gástrico está associado com refluxo gastro-esofágico e distúrbios alimentares. A frequência da ingestão de alimentos e bebidas ácidas e como eles são consumidos são importantes na erosão causada pela dieta. A progressão do desgaste dental é reconhecida por ser lenta com períodos de atividade e inatividade. Embora restaurações possam ser indicadas, a prevenção e monitoramento permanecem como importantes estratégias em manter a integridade do dente.

Lussi et al., em 2006, realizaram uma revisão bibliográfica sobre o diagnóstico, fatores de risco e prevenção do desgaste dental por erosão. Verificaram que a aparência lisa, glazeada, com ausência de periquimáceas e esmalte intacto ao longo da margem gengival, com fossas e estrias oclusais são sinais típicos de erosão do esmalte. Em estágios avançados, é difícil distinguir entre as influências da erosão, atrição ou abrasão durante o exame clínico. Fatores biológicos, comportamentais e químicos juntos contribuem, com o passar do tempo, para 0 desgaste da superfície dental ou sua proteção. Para acessar os fatores de risco, pacientes deveriam anotar sua dieta por um período de tempo. Baseado nesta análise, um programa de prevenção individualizado poderia ser sugerido para 0 paciente. Este pode incluir conselhos sobre a dieta, regimes de otimização do uso do flúor, uso de medicamentos tamponantes e motivação para hábitos de escovação não destrutivos.

Bartlett (2007) novamente revisou os motivos do desgaste dental e verificou que a erosão é um dos principais fatores que contribuem para o desgaste patológico dos dentes. A erosão pode ser causada tanto por ácidos intrínsecos quanto ácidos extrínsecos. Os resultados do desgaste dental podem causar danos significativos para os dentes, os quais podem requerer complexo e oneroso tratamento protético. 
O autor verificou que medidas preventivas, incluindo limitar a frequência de exposição dos dentes aos ácidos e uso de flúor e agentes adesivos-dentinários, poderiam prolongar a vida do dente.

\subsubsection{Erosão por ácidos extrínsecos}

A erosão dental pode ser causada por ácidos de origem extrínseca como os oriundos da dieta, medicamentos e do ambiente.

Touyz (1994) avaliou a acidez e a titulação dos sucos de frutas vendidos no Canadá, em vista da capacidade dos mesmos em causar erosão nos tecidos dentais. Os sucos estudados foram de laranja, maçã, uva, limão, ponche de laranja e de uva. $\mathrm{O}$ pH de cada exemplar foi medido três vezes. Na titulação, às bebidas foi acrescentado hidróxido de sódio $(\mathrm{NaOH})$ até que elas atingissem o pH 10 . Os resultados mostraram que o $\mathrm{pH}$ variou de 2,85 à 3,86 . O suco de laranja estudado obteve o mais alto $\mathrm{pH}(3,86)$ e o de limão o mais baixo $(2,85)$. O suco de laranja precisou de maior quantidade de $\mathrm{NaOH}$ para atingir o $\mathrm{pH} 10 . \mathrm{O}$ autor concluiu que não era apenas o pH o fator causal da erosão dental, mas que a quantidade, tipo de ácido e componentes químicos presentes, também eram importantes.

Lussi, Jaeggi e Jaeggi-Schärer (1995) investigaram se o potencial erosivo de uma bebida sobre o esmalte humano podia ser previsto pelo exame da composição da bebida. Amostras de esmalte foram divididas em grupos e imersas por 20 minutos em bebidas consideradas ácidas. A dureza superficial do esmalte foi medida antes e depois da imersão. A concentração de fosfato, flúor, o pH, assim como a 
titulação de cada bebida foram determinadas. O suco de maçã causou a maior diminuição na dureza superficial do esmalte seguido pelo Scheweppes, refrigerantes Orangina e Grapefruit. A menor diminuição na dureza do esmalte foi na imersão em Fendant e Isostar orange, dois tipos de refrigerante. Bebidas com alta concentração de fosfato tiveram baixo efeito na microdureza. Foi possível caracterizar o potencial erosivo de uma bebida pela sua titulação, seu pH, concentração de fosfato e flúor. Entretanto, devido à formação da película adquirida, assim como a capacidade tampão salivar, valor de pH e fluxo dos fluidos bucais, o efeito erosivo das bebidas é reduzido em condições in vivo.

Zero (1996) revisando os fatores extrínsecos ligados à etiologia da erosão dental, constatou que vários fatores podiam causar erosão e os dividiu em grupos relacionados ao ambiente ou à atividade ocupacional, à dieta, aos medicamentos e ao estilo de vida. Os fatores ocupacionais eram principalmente relacionados a indivíduos que se expunham diretamente a gases e aerossóis ácidos como os trabalhadores de fábricas de baterias, galvanização, fertilizantes; incluíam também os funcionários de laboratórios que pipetavam ácidos e degustadores de vinho. Os fatores relacionados à dieta receberam mais atenção por afetarem um largo segmento da população. A maioria dos alimentos e bebidas com baixo $\mathrm{pH}$, como os sucos de frutas cítricas, refrigerantes, bebidas esportivas tinham potencial de causar erosão dental. Os medicamentos e produtos de higiene bucal também podiam ter potencial para causar erosão dental, mas em geral, eram empregados em pequenas quantidades e por curto período, limitando sua ação erosiva. O estilo de vida estava relacionado ao tipo de alimento e à bebida consumidos, à frequência e ao tempo de consumo. A prática de higiene bucal era considerada o fator mais importante na influência do desenvolvimento clínico da erosão dental, uma vez que a combinação 
da frequência do consumo de alimentos e bebidas ácidas e o super zelo na higiene bucal poderiam ser considerados fatores de alto risco. Entretanto, o autor observou que uma discussão sobre a erosão dental, sem incluir outros fatores etiológicos envolvidos no desgaste dental, como, a abrasão e a atrição, era de limitado valor clínico. Considerou que o desgaste dental era um processo acumulativo e, em larga extensão, irreversível.

Larsen e Nyvad (1999) compararam o pH e a titulação de vários refrigerantes com seu efeito erosivo sobre a solubilidade da apatita. Dezoito bebidas foram avaliadas (refrigerantes, águas minerais e sucos de laranja). O pH e a concentração de cálcio, fosfato e flúor foram determinados. A titulação foi determinada até o pH atingir 5,5 e 7,0. Amostras de esmalte de dentes humanos foram expostas por uma semana às bebidas. A profundidade da erosão na superfície dos dentes, após a imersão nas bebidas, ficou em torno de $3 \mathrm{~mm}$ para os espécimes imersos em refrigerantes e sucos de laranja frescos. As superfícies foram levemente afetadas para a maioria das águas minerais. A dissolução do esmalte aumentou quando o pH da bebida diminuía. Nas bebidas com menores pHs, foi necessário mais $\mathrm{NaOH}$ para trazê-las ao $\mathrm{pH}$ de neutralidade. Em particular, o suco de laranja precisou de mais $\mathrm{NaOH}$ para se neutralizar.

A relação entre erosão dental, $\mathrm{pH}$ e os hábitos de ingestão de bebidas, em um grupo de adolescentes, foi investigada por Moazzez, Smith e Bartlett (2000). O $\mathrm{pH}$ foi medido simultaneamente na superfície de quatro dentes em 11 pacientes, com idade entre 10 a 16 anos, com erosão, e em 10 pacientes- controle sem erosão. As medições foram feitas antes, durante e depois dos pacientes beberem $330 \mathrm{ml}$ de refrigerante tipo cola. A maneira e o tempo em que a bebida foi ingerida também foram observados, assim como o fluxo salivar e a capacidade tampão da saliva. Os 
resultados mostraram que os pacientes com erosão beberam mais refrigerantes e beberam diretamente da lata mais frequentemente do que os pacientes-controle. $O$ $\mathrm{pH}$ da superfície vestibular dos molares superiores permaneceu mais baixo, por mais tempo, em pacientes portadores de erosão do que nos pacientes isentos de erosão. A superfície vestibular dos incisivos superiores teve exposição mais prolongada a baixos pHs no grupo controle. Os autores concluíram que o padrão do pH bucal diferiu entre os pacientes com e sem erosão, depois de beberem bebidas ácidas, e isto podia ser relacionado aos diferentes hábitos de ingestão, influenciando o padrão de erosão naqueles pacientes.

Tendo em vista a ocorrência de um maior número de dentes com lesões por erosão, Sobral et al. (2000), analisaram o pH de algumas frutas através de seus sucos (limão, maracujá, acerola, morango, caju, uva, laranja, goiaba, abacaxi e manga) e de bebidas industrializadas supostamente ácidas (Gatorade, Coca-Cola, Coca-Cola diet, Guaraná, Guaraná diet, iogurte natural, vitamina C). Verificaram que os valores do pH oscilaram de 2,13 a 4,86 (média 3,48), sendo o suco de limão a bebida natural mais ácida $(2,13)$, e a Coca-Cola, a bebida industrializada com o menor $\mathrm{pH}(2,36)$. A diluição e o tempo decorrido entre o preparo ou abertura das embalagens e a medição não alteraram consideravelmente $0 \mathrm{pH}$. Os autores concluíram que todas as bebidas e sucos testados mostraram valores de $\mathrm{pH}$ abaixo do $\mathrm{pH}$ crítico de dissolução da estrutura dental $(5,5)$. Os resultados obtidos sugeriram a possibilidade de desmineralização da estrutura dental quando essas bebidas e sucos eram consumidos.

Dugmore e Rock, em 2004, examinaram os possíveis fatores etiológicos da erosão dental em crianças. Uma amostra aleatória de 1753 crianças foi examinada com 12 anos e 1308 foram re-examinadas aos 14 anos. As crianças também 
responderam questionários sobre os hábitos alimentares e presença de asma. $\mathrm{Na}$ idade de 12 anos uma associação positiva foi encontrada entre erosão e experiência de cárie, consumo de suco de fruta ou "fizzy pop". A presença de cálculo ou o consumo de frutas (exceto maçã ou frutas cítricas) reduziu as chances de erosão. 0 alto consumo de bebidas carbonatadas - refrigerantes, aumentou a presença de erosão aos 12 anos em 25,2\% e foi em forte indicador da quantidade de erosão encontrada aos 14 anos.

Lussi, Jaeggi e Zero, em 2004, revisaram a literatura sobre o papel da dieta na etiologia da erosão dental. Os ácidos de origem intrínseca e extrínseca são os principais fatores etiológicos da erosão dental. Há evidências que alimentos e bebidas ácidas têm influência no desenvolvimento da erosão. Entretanto, o pH da dieta exclusivamente não é pressuposto de seu potencial em causar erosão, outros fatores modificam o processo erosivo. Fatores químicos (valor de pKa, adesão e propriedades de quelação, conteúdo de cálcio, fosfato e flúor), comportamentais (modo de comer e beber, estilo de vida, excesso de consumo de ácidos) e biológicos (fluxo salivar, capacidade tampão, composição da saliva, formação da película adquirida, composição dental, anatomia dental e dos tecidos moles) também interferem no desenvolvimento da lesão de erosão. Por isso, recomendações aos pacientes dos riscos para a erosão dental, tais como a redução da exposição dental ao ácido, devem ser feitos.

Hooper et al. (2005) desenvolveram e testaram uma metodologia in situ, a qual simulava o consumo de bebidas esportivas. Para selecionar a bebida esportiva para o estudo in situ, bebidas disponíveis comercialmente foram examinadas quanto ao potencial erosivo in vitro. Cinco bebidas foram analisadas (Isostar pó, Isostar líquido, Umbro, Gatorade pó, Gatorade líquido). A bebida que causou maior erosão 
in vitro foi o Gatorade líquido por isso foi escolhido para o estudo in situ. O estudo in situ comparou o efeito erosivo do Gatorade com a água mineral (controle), durante período de 10 dias em 10 voluntários saudáveis. Os voluntários usaram aparelhos móveis superiores contendo dois espécimes de esmalte humano, das 9 da manhã às 5 da tarde, o regime de ingestão das bebidas foi $350 \mathrm{ml} \mathrm{em} 10 \mathrm{~min}$, descanso de $5 \mathrm{~min}, 650 \mathrm{ml}$ em $25 \mathrm{~min}$, descanso de $5 \mathrm{~min}, 500 \mathrm{ml}$ em $10 \mathrm{~min}$ e descanso de 5 min. As medições da perda de esmalte foram feitas nas amostras depois de 5 e 10 dias em perfilômetro. Nenhum espécime exposto à bebida controle mostrou erosão apreciável. Erosão ocorreu com a bebida teste, mas o grau de erosão variou entre os voluntários. A bebida esportiva causou significativamente mais erosão in situ do que a água. Houve marcada variação na susceptibilidade à erosão entre os voluntários.

Rees, Loyn e Gilmour (2006) compararam o potencial erosivo do suco de laranja padrão (Tropicana) com um novo suco de laranja de baixa acidez. Três parâmetros foram comparados em laboratório: $\mathrm{pH}$, neutralização do ácido e a habilidade para causar erosão em esmalte. $\mathrm{O}$ pH do suco padrão era de 3.88 comparado ao suco de menor acidez que era de 4.18. A neutralização ácida do suco de menor acidez foi mais rápida $(16,96 \mathrm{ml}$ de $0,1 \mathrm{M} \mathrm{NaOH})$ do que do suco padrão $(28,46 \mathrm{ml})$. O suco de menor acidez produziu menor erosão dental $(2,49 \mu \mathrm{m})$ do que o suco padrão $(5,23 \mu \mathrm{m})$. De acordo com os pesquisadores estes achados laboratoriais precisam ser confirmados em experimentos clínicos antes que este produto possa ser recomendado sem restrições para pacientes que são clinicamente susceptíveis à erosão.

Auad e Moynihan (2007) estudaram a relação da dieta com a erosão dental. Verificaram uma crescente associação entre o consumo de refrigerantes e a erosão 
dental. O potencial erosivo de uma bebida pode ser influenciado pelo seu pH, tipo e quantidade de ácidos presentes e também sua concentração de cálcio, fosfato e flúor. O alto consumo de bebidas alcoólicas pode contribuir para a erosão dental não somente devido ao conteúdo ácido das bebidas, mas também como resultado de outras condições associadas com o hábito, como refluxo gastro-esofágico, vômitos frequentes e alterações salivares. Julgam utópico recomendar o total banimento do consumo de bebidas ácidas, mas recomendam a redução na frequência e quantidade do consumo de bebidas e alimentos ácidos e especialmente desencorajam o consumo de bebidas ácidas no horário de dormir, recomendando o consumo de alimentos remineralizantes, como o queijo, após a ingestão de alimentos ácidos.

Bassiouny, Kuroda e Yang (2007) monitoraram o efeito da exposição às bebidas carbonatadas aciduladas na topografia e perfil geométrico na dentição humana. Dois representantes de bebidas carbonatadas aciduladas, um caramelizado (Pepsi Cola) e outro não caramelizado (Sprite) foram avaliados junto com líquidos controles (controle negativo - água/ controle positivo - ácido acético). Dentes foram expostos aos líquidos, avaliações qualitativas das mudanças topográficas e análises quantitativas de traçados de radiografias digitais foram feitas em intervalos de 4 semanas até completar 20 semanas. Os efeitos erosivos das bebidas carbonatadas foram similares entre elas, mas menores do que aqueles causados pelo ácido acético. Estes efeitos foram indicados pelas mudanças na topografia do esmalte (tais como cor, translucidez, textura e integridade) assim como pela redução no perfil dos espécimes com diminuição na altura de cúspide, redução no raio coronário. 
Jaeger et al. (2008) avaliaram se a composição das bebidas influenciam a aferição do seu potencial erosivo. Também avaliaram a influência da exposição a pequenos e grandes volumes de bebidas na erosão. Onze bebidas foram estudadas: água (controle), duas bebidas alcoólicas com base em vodca e rum, duas cervejas, dois refrigerantes, dois sucos de frutas, um ice tea e uma bebida energética. Para cada bebida quinze espécimes de esmalte bovino foram usados: 5 para análise química, e 10 para análise perfilométrica. Após exposição às bebidas por 63 minutos, foi analisado o conteúdo de Ca e P. Os espécimes para perfilometria foram submersos em $500 \mathrm{ml}$ ou $1 \mathrm{ml}$. A análise perfilométrica (para 1 e $500 \mathrm{ml}$ ) mostrou menores perdas de esmalte do que a análise química. Menores perdas de esmalte foram encontradas na perfilometria de $1 \mathrm{ml}$ comparada com a de $500 \mathrm{ml}$ somente para os refrigerantes. Os autores concluíram que a composição das bebidas teve um efeito significativo na determinação do potencial erosivo com a análise química. E a composição também influencia no efeito de pequeno versus grandes volumes de exposição, indicando a necessidade de padronização dos parâmetros de exposição nos testes de erosão.

\subsubsection{Erosão por ácidos intrínsecos}

Spigset (1991) revisou as manifestações orais da bulimia nervosa e realizou um estudo com questionários dos sintomas bucais em 34 mulheres com bulimia nervosa. Vinte e três $(68 \%)$ das pacientes reportaram sintomas dentais, tais como hipersensibilidade (47\%), dor (18\%), fraturas (6\%) e aumento na incidência de cárie 
(29\%). Doze mulheres (35\%) reportaram boca seca ou olhos secos diariamente, e dez (29\%) reportaram inchaço intermitente da glândula parótida. O presente estudo indica que mulheres com bulimia nervosa frequentemente tem sintomas dentais (principalmente hipersensibilidade e dor) assim como boca seca e inchaço da parótida. Elas estão em risco de desenvolver significantes erosões dentais e provável aumento na incidência de cáries. É de grande importância que os pacientes com bulimia nervosa recebam informações sobre a doença e o tratamento para suas manifestações dentais.

Meurman et al. (1994) avaliaram 117 pacientes com refluxo gastro-esofágico com respeito à severidade de sua doença e manifestações bucais, dentais e salivares. Vinte e oito pacientes tinham erosão dental. Nenhuma alteração na mucosa pode ser observada em relação ao refluxo. Em média, os pacientes com erosão eram mais velhos ( 54 × 49 anos) e a duração média da doença era maior em comparação com aqueles sem erosão (17 x 11 anos). A severidade da doença foi mais marcante entre os pacientes com erosão dental. Nenhuma diferença estatística foi observada entre os grupos em relação aos parâmetros salivares estudados, embora o número de pacientes com baixa capacidade tampão salivar fosse maior entre os pacientes com erosão. Pacientes que tomavam $\beta$-bloqueadores ou tranquilizantes tinham mais erosão do que os outros. A frequência de consumo de alimentos e bebidas ácidas foi determinada por um questionário e não diferiu entre os pacientes com e sem erosão dental. Portanto o refluxo severo por longo tempo foi considerado como sendo potencialmente lesivo ao dente, visto que formas mais brandas da doença não causaram necessariamente efeitos colaterais aos dentes.

Robb, Smith e Geidrys-Leeper (1995) revisaram os efeitos das desordens alimentares (anorexia e bulimia) na erosão dental. Avaliaram os efeitos destas 
desordens alimentares na erosão dos dentes em relação à severidade da erosão e frequência do vômito auto-induzido. Cento e vinte pacientes com desordens alimentares e um número igual de pacientes-controle com a mesma idade, sexo e classe social foram estudados. Os pacientes com problemas alimentares foram divididos em subgrupos de acordo com a desordem alimentar: anorexia nervosa abstênia (AAN), anorexia nervosa com vômito (VAN), bulimia nervosa (BN). Foram avaliadas as superfícies cervical, vestibular, oclusal e lingual de todos os dentes dos pacientes. Todos os subgrupos de desordem alimentar apresentaram significativamente mais desgaste dental do que o grupo controle, com as diferenças sendo mais marcantes nos grupos com a ocorrência de vômitos. Para o grupo de AAN o desgaste foi maior nas superfícies vestibulares e oclusal. Para os grupos VAN e BN o desgaste em várias superfícies dos dentes superiores e inferiores foi encontrado. Não foi encontrada nenhuma relação consistente entre frequência e duração dos episódios de vômito com a severidade da erosão.

Bartlett, Evans e Smith (1996) revisaram a relação entre o refluxo gastroesofágico e a erosão dental. Estabeleceram que o ácido regurgitado do estômago para a boca pode causar erosão nos dentes. Condições como a anorexia e bulimia nervosa, alcoolismo e desordens gástricas causam erosão palatina dos dentes. 0 fator em comum destas condições é o papel apresentado pelo estômago e esôfago no movimento ácido. A movimentação do ácido pelo baixo esfíncter esofágico para o esôfago é descrito como refluxo gastro-esofágico. Em alguns pacientes o movimento do ácido torna-se crônico, doloroso e requer tratamento e é chamado de doença do refluxo gastro-esofágico (GORD). É notado por muitos gastroenterologistas que a GORD é um fracasso do mecanismo anti-refluxo, o qual é predominantemente 
controlado pelo baixo esfíncter esofágico. Uma vez que o ácido alcança a boca o potencial de dano para os dentes existe.

Bartlett e Smith (1996) acompanharam os exames para diagnóstico de GORD de pacientes que apresentavam erosão na superfície palatina dos dentes. Nem todos os pacientes apresentavam sintomas do refluxo gastro-esofágico, mas após os exames diagnósticos de monitoramento por 24 horas do pH esofágico, motricidade do esfíncter e pressão esofágica, foi verificado que pacientes apresentavam quadro diagnosticado como GORD. A falta de sintomas nem sempre prova que o refluxo não está causando a erosão dental. Pacientes, nos quais nenhuma causa óbvia pode ser encontrada para a erosão dental deveriam ser investigados quanto à doença do refluxo gastro-esofágico. Nestes casos a erosão dental pode ser o único sinal óbvio que o refluxo esteja ocorrendo.

Scheutzel (1996) em revisão da literatura revelou que a erosão dental devido a fatores intrínsecos é causada pelo ácido gástrico que alcança a cavidade bucal e os dentes como resultado de vômito ou refluxo gastro-esofágico. As manifestações clínicas da erosão não ocorrem até que o ácido gástrico tenha agido nos tecidos duros dentais regularmente por um período de vários anos. A erosão causada por fatores intrínsecos tem sido observada somente em doenças as quais se associam com vômito crônico ou refluxo gastro-esofágico permanente por longo período. Exemplos desta condição incluem as desordens do trato alimentar superior, doenças endócrinas, e do metabolismo, casos de efeitos colaterais e abuso de medicamentos, doenças psicossomáticas como, por exemplo, anorexia e bulimia ou ruminação.

O’Sullivan et al. (1998) investigaram a relação entre erosão dental e refluxo gastro-esofágico (GORD) em crianças. Cinquenta e três crianças de 2 a 16 anos 
com moderado a severo GORD definidas pelo monitoramento do $\mathrm{pH}$ do esôfago, foram examinadas quanto a erosão dental. Um questionário investigou os hábitos alimentares, outras condições médicas relevantes e os fatores de risco para erosão também foram questionados. Os resultados mostraram que a prevalência da erosão dental foi baixa, com somente 9 (17\%) das crianças apresentando algum sinal de erosão, e destas somente uma tinha erosão envolvendo dentina. Estes resultados sugerem que a erosão dental pode não ser um grande problema em crianças com GORD como em adultos.

Rytomaa et al. (1998) avaliaram as condições dentais de pacientes bulímicos. Trinta e cinco pacientes diagnosticados com bulimia e 105 pacientes controles de igual idade, sexo e nível educacional foram examinados clinicamente. Fatores associados com erosão dental e cárie foram avaliados em uma entrevista. Erosão dental severa e cáries foram significativamente mais comuns entre os bulímicos do que nos controles. Os bulímicos comumente tinham baixo fluxo salivar (não estimulado), mas outros fatores de risco para erosão dental (dieta ácida, higiene dental) não diferiram do grupo controle. Sensação de boca seca foi mais comum entre os bulímicos do que entre os controles, e os bulímicos tinham sensibilidade dental aumentada ao frio e ao toque.

Bidwell, Dent e Sharp (1999) apresentaram um caso clínico de um homem bulímico mostrando que a regurgitação crônica resultante da alimentação descontrolada causou significante erosão no esmalte com o passar do tempo. A dentição de um paciente bulímico fornece várias pistas para alertar para o hábito do paciente e a necessidade de encaminhá-lo a um tratamento multidisciplinar.

Gregory-Head et al. (2000) avaliaram a associação entre a perda de estrutura dental como resultado da erosão e a doença do refluxo gastro-esofágico. Vinte 
adultos que procuraram o departamento de gastroenterologia para investigação de doença no trato gastro-esofágico foram também avaliados para sinais de erosão dental. Todos os indivíduos foram submetidos a uma avaliação dental que incluiu um histórico para determinar potenciais fatores etiológicos responsáveis pela erosão dental. Eles foram examinados clinicamente para quantificar a perda de estrutura dental. Exames endoscópicos e pHmanometria de 24 horas foram feitos para determinar quais indivíduos apresentavam refluxo gastro-esofágico. Dez indivíduos foram diagnosticados com doença gastro-esofágica. Todos os indivíduos diagnosticados com refluxo tinham escores de desgaste mais altos comparados com os controles. Os pacientes com refluxo apresentaram escores de desgaste mais altos em todos os quadrantes, exceto na região anterior mandibular onde não se encontrou diferença com o controle. Os resultados indicaram que existe relação entre perda de estrutura dental e a ocorrência de refluxo gastro- esofágico.

Bartlett e Coward (2001) compararam o efeito erosivo do suco gástrico com o da Coca-Cola sobre o esmalte e dentina, medindo o cálcio liberado de dentes humanos, utilizando espectrometria de absorção atômica. A média do $\mathrm{pH}$ do suco gástrico foi de 2,92 e a titulação foi de $0,68 \mathrm{ml}$. O refrigerante apresentou pH de 2,45 e a titulação de $0,29 \mathrm{ml}$. As amostras ficaram imersas em $2 \mathrm{ml}$ dos respectivos ácidos por 2 minutos, foram lavados em seguida com água, este processo foi repetido nove vezes. A quantidade média de cálcio liberado do esmalte para o ácido gástrico foi de $69,6 \mu \mathrm{g} \mathrm{L}^{-1}$ e $62,4 \mu \mathrm{g} \mathrm{L}^{-1}$ da dentina. Para o refrigerante liberaram em média 18,7 $\mu \mathrm{g}$ $\mathrm{L}^{-1}$ e $18,6 \mu \mathrm{g} \mathrm{L}^{-1}$ esmalte e dentina, respectivamente. A diferença na liberação de cálcio para o suco gástrico e o refrigerante foi estatisticamente significante para esmalte e dentina. Concluiu-se que o suco gástrico tem maior potencial para erosão que o refrigerante. 
Silva et al. (2001) investigaram os efeitos da doença do refluxo gastroesofágico (GORD) na dentição, função salivar e mucosa oral. Trinta e um pacientes com esofagite foram submetidos à avaliação médica, a qual incluiu tomada do histórico médico, biópsia gastroduodenal e esofágica, exame estomatológico. Este exame consistiu de avaliação física extra e intra-bucal, teste de fluxo, capacidade tampão e pH salivar, e biópsia e morfometria da mucosa palatina, assim como da tomada do histórico dos hábitos alimentares dos pacientes. Catorze voluntários saudáveis, da mesma população, foram usados como grupo controle. Nenhuma relação entre GORD e mudanças na cavidade oral foi mostrada pelos testes salivares, exame clínico oral ou exame histopatológico da mucosa palatina. Entretanto, análises morfométricas do epitélio palatino mostraram diferenças estatisticamente significantes entre os pacientes com GORD e o grupo controle, com aumento da razão lúmen e superfície basal o que corresponde à atrofia do epitélio, e aumento na quantidade de fibroblastos nos pacientes com GORD. Concluíram que GORD está associado com alterações microscópicas na mucosa palatina as quais só foram detectadas por morfometria.

Erosão do esmalte pode ser um sinal clínico de refluxo gastro-esofágico sem sintomas. Ali et al. (2002) examinaram um paciente com 30 anos, sexo masculino que queixava-se do amarelamento dos seus dentes e perda das pontas dos dentes anteriores. Após exame clínico verificou-se erosão dental da face palatina dos incisivos e margem incisal e oclusal de dentes posteriores com perda de dimensão vertical. O paciente não relatava nenhum problema gastrointestinal ou bulimia. Ele foi encaminhado para um gastroenterologista e após exames ele foi diagnosticado como tendo refluxo gastro-esofágico. 
Segundo Christensen (2002) várias condições causam rápida e debilitante erosão dos dentes. Uma causa comum é a bulimia. Os dentistas frequentemente encontram pacientes que tem este problema. Pessoas que tem atividade bulímica por um período moderado de tempo (meses a poucos anos) têm severa erosão na superfície lingual dos dentes superiores anteriores. As superfícies linguais e oclusais dos molares superiores têm moderada erosão na superfície lingual e oclusal. $\mathrm{O}$ dentista deverá confirmar a possibilidade de bulimia, encaminhar o paciente para um tratamento, aconselhá-lo sobre sua condição e restaurar a boca do paciente para o estado de saúde e estética aceitável.

Barron et al., em 2003, estudaram a erosão dental relacionada com a doença do refluxo gastro-esofágico. Verificaram que os dentistas são frequentemente os primeiros profissionais da saúde a diagnosticar o refluxo em decorrência da presença de lesões de erosão dental com características de lesões por fontes ácidas intrínsecas. O refluxo gastro-esofágico é a passagem do conteúdo gástrico para o esôfago podendo chegar à cavidade bucal e a doença do refluxo gastro-esofágico é definida como os sintomas ou complicações do refluxo. O tratamento da erosão dental resultante de refluxo gastro-esofágico envolve uma abordagem multidisciplinar entre dentistas e gastroenterologista. Quando possível a erosão dental deve ser tratada com intervenção mínima, e tal tratamento incluiria o controle da microbiota, remineralização, restaurações adesivas.

Lackey e Barth (2003) verificaram que a erosão química bucal pode ser causada por vários fatores. O mais significante e frequente é a doença do refluxo gastro-esofágico. O profissional dentista está numa posição de identificar sinais bucais sutis da doença e tem a obrigação de alertar os sinais de refluxo gastro- 
esofágico ao paciente fazendo apropriadas referências a médicos quando necessário.

Van Roeckel (2003) apresentou um caso clínico onde um adolescente de 14 anos apresentava perdas extensas de esmalte em dentes anteriores e posteriores com perda de dimensão vertical. O paciente foi diagnosticado como tendo bruxismo mas, o padrão de desgaste não era característico de atrição e sim de erosão, pois até as faces lingual e vestibular estavam envolvidas. O paciente foi encaminhado para um gastroenterologista e diagnosticado como tendo refluxo gastro-esofágico. Apropriado tratamento médico foi realizado e posteriormente, feito a reabilitação dental com coroas metalo-cerâmicas. O autor enfatiza que somente tratado o problema médico é possível dar continuidade ao tratamento odontológico por isso a importância do tratamento multidisciplinar.

Jensdottir et al., em 2004, determinaram a prevalência de erosão dental em jovens adultos islandeses (19 à 22 anos) e pacientes com refluxo gastro-esofágico (GORD) em relação ao consumo de bebidas e a presença de refluxo. Oitenta participantes compreendendo 57 adultos e 23 pacientes com GORD foram avaliados. Todos os participantes responderam a um detalhado questionário de frequência de consumo de vários tipos de bebidas e foram submetidos a uma avaliação clínica para diagnóstico de lesões de erosão dental. Não houve diferença na prevalência de erosão dental entre o grupo dos adultos e os pacientes de GORD. Os resultados mostraram baixa prevalência de erosão dental em pacientes com GORD. Entretanto ao combinar os dois grupos, um risco três vezes maior de ter erosão em molares ou incisivos foi encontrado para os participantes que bebiam Coca-Cola três vezes ou mais durante a semana. E também o escore das lesões em molares foi mais elevado naqueles que bebiam mais de 1 litro de refrigerante 
(qualquer marca) por semana. Os autores concluíram que a frequência de consumo de bebidas (refrigerantes) é um forte fator de risco no desenvolvimento de erosão dental.

Moazzez, Bartlett e Anggiansah, em 2004, avaliaram a prevalência do desgaste dental, sintomas de refluxo e parâmetros salivares em um grupo de pacientes que tinham suspeitas de doença de refluxo gastro-esofágico (GORD) e compararam com um grupo controle. O desgaste dental, fluxo salivar estimulado e capacidade tampão e sintomas de GORD foram avaliados. Nos pacientes com suspeita de GORD foram feitos testes de manometria e de 24 horas de avaliação do $\mathrm{pH}$ para o diagnóstico da doença. Pacientes com sintomas de GORD e subsequentemente diagnosticados com GORD tinham maior desgaste dental principalmente na face palatina. A capacidade tampão salivar da saliva estimulada do grupo controle foi maior do que dos pacientes com sintomas de GORD. Pacientes com rouquidão tiveram fluxo salivar menor, comparados com aqueles sem rouquidão. Os autores concluíram que o desgaste dental envolvendo dentina foi mais prevalente em pacientes que se queixavam de sintomas de GORD e naqueles diagnosticados como tendo GORD do que no grupo controle.

Moazzez, Anggiansah e Bartlett (2005) compararam o pH a $2 \mathrm{~cm}$ acima do esfíncter esofágico superior e a $5 \mathrm{~cm}$ acima do esfíncter esofágico inferior em 31 pacientes que se queixavam de sintomas de refluxo gastro-esofágico e em 7 pacientes controle. A avaliação foi feita durante 24 horas com eletrodos introduzidos com sonda naso-gástrica. Nos pacientes com queixa de refluxo a proporção de tempo (com paciente em posição supino - dormindo) que o pH ficou abaixo de 4, acima do esfíncter inferior, foi significativamente maior do que nos pacientes controle. A proporção de tempo quando o $\mathrm{pH}$ a $2 \mathrm{~cm}$ acima do esfíncter superior foi 
menor que 5,5 também foi significativamente maior nos pacientes com queixa de refluxo do que nos controles. Neste grupo de pacientes que apresentam sintomas de refluxo o ácido gástrico passa através do esfíncter superior e aumenta o potencial para erosão. Houve correlação estatística entre a proporção de tempo em que o pH ficou abaixo de 5,5 acima do esfíncter superior e o número de desgaste palatino com escore 2 e 3 nos pacientes com refluxo.

Oginni, Agbakwuru e Ndububa, em 2005, compararam a prevalência de erosão dental em pacientes com diagnóstico de GORD e pacientes controles. Foram avaliados 225 pacientes, sendo que 100 compunham o grupo controle (sem GORD) e 125 pacientes diagnosticados com GORD. Vinte pacientes com GORD apresentaram erosão dental nos dentes anteriores superiores. A prevalência de erosão em pacientes com GORD (16\%) foi estatisticamente maior do que a encontrada no grupo controle (5\%). Os autores concluíram que a erosão dental pode ser considerada como uma manifestação extra-esofágica de GORD.

Benages et al. (2006) examinaram 181 pacientes com refluxo gastroesofágico e 72 voluntários saudáveis (controle). A avaliação clínica incluiu sexo, idade, índice de massa corporal e consumo de tabaco e álcool. O exame dental avaliou os seguintes parâmetros: presença e número de erosão dental, localização e severidade. Comparado com o grupo controle, a porcentagem de erosões dentais foi significativamente maior no grupo com refluxo $(12,5 \times 47,5 \%)$ assim como a severidade das lesões. Os autores concluem que dado a alta prevalência de erosões dentais em pacientes com refluxo, a colaboração entre gastroenterologistas e dentistas é necessária para identificar o envolvimento dental em pacientes diagnosticados com refluxo gastro-esofágico. Em contraste, sujeitos com erosões 
dentais inexplicáveis deveriam ser encaminhados para um gastroenterologista para investigar a presença de refluxo gastro-esofágico.

Linfante-Oliva et al. (2008) estudaram as alterações orais em pacientes com distúrbios alimentares. Foram examinadas 17 mulheres com distúrbios alimentares (anorexia e bulimia), com idades entre 13-32 anos. As principais alterações observadas foram erosões dentais, nas faces palatinas dos dentes anteriores superiores principalmente nas pacientes com bulimia. Observaram aumento da glândula parótida, diminuição no fluxo salivar e alteração no pH salivar. Concluíram que significativas alterações orais ocorrem em pacientes com distúrbios alimentares e que estas alterações têm um impacto adverso à saúde oral dos pacientes, levando ao acúmulo de irritantes locais e aumentando o risco de doenças orais. Medidas preventivas são, portanto, recomendadas a este grupo de pacientes. Sugerem que pacientes com distúrbios alimentares devem ser encorajados a fazer exames odontológicos a intervalos regulares e utilizar métodos de prevenção para erosão dental.

Pace et al. (2008) revisaram a literatura para estudar a relação entre erosão dental e refluxo gastro-esofágico. Estudos que avaliavam a prevalência de erosão dental em indivíduos com refluxo ou vice-versa foram identificados no Medline e Cochrane controlled Trials. Foram avaliados 17 artigos. Os estudos diferiam largamente em seu delineamento, método diagnóstico do refluxo, duração do acompanhamento e consequentemente nos resultados. A prevalência média de erosão dental em pacientes com refluxo foi de $24 \%$, com grande variação $(5-47,5 \%)$, e a prevalência média de refluxo em pacientes adultos com erosão dental foi de $32,5 \%$ (variando de $21-83 \%$ ) e na população pediátrica foi de 17\% (14-87\%). Esta revisão sistemática mostrou que há forte associação entre refluxo gastro-esofágico e 
erosão dental. A severidade das lesões de erosão parece estar correlacionada com a presença de sintomas do refluxo, e também, pelo menos em adultos, com a severidade da exposição oral ao pH ácido. A inspeção da cavidade oral na pesquisa por erosão dental deveria tornar-se rotina em pacientes com refluxo gastroesofágico.

\subsection{Métodos de Controle da Erosão Dental}

O principal método de controlar a erosão dental é evitar o contato do ácido, seja de fonte intrínseca ou extrínseca, com a superfície dental. Entretanto, nem sempre isso é possível, por isso outras formas de controle devem ser realizadas.

Amaechi e Higham (2005) revisaram a etiologia, patogênese e fatores modificadores da erosão dental para traçar estratégias de prevenir ou limitar os danos da erosão dental e proteger os remanescentes de mais destruição erosiva. Sugeriram como medidas de prevenção: aumentar a remineralização e resistência ácida da superfície do esmalte amolecido pelo desafio ácido utilizando agentes remineralizantes como enxaguatórios fluoretados, pastilhas, leite, gel fluoretado e vernizes; reduzir o potencial erosivo dos produtos ácidos com a adição de cálcio, aumentar o fluxo salivar com gomas de mascar com flúor; proteger e restaurar os dentes danificados pela erosão; prover proteção mecânica contra o desafio ácido em trabalhadores que estão em ambiente comprometedor; educação e aconselhamento como a diminuição na frequência de ingestão de ácidos na dieta e mudança dos hábitos e tipo de vida que predispõe ao desenvolvimento da erosão dental. Efetivo 
aconselhamento dos regimes preventivos para erosão deveria envolver todos os profissionais da saúde, dentistas, médicos, farmacêuticos, psicólogos.

\subsubsection{Flúor}

O flúor é a principal forma de prevenção de cáries e foi, portanto, natural que o flúor fosse considerado como possível veículo para controle da erosão dental (HOLBROOK; ARMADOTTIR; KAY, 2003).

Ganss et al. (2001) avaliaram o efeito do flúor na progressão da desmineralização do esmalte e dentina humana causada por erosão utilizando um modelo cíclico de de-remineralização in vitro. O conteúdo mineral expresso em micrometros foi determinado diariamente por microrradiografia longitudinal e apresentado como a perda acumulada por 5 dias. Para a desmineralização, todos os espécimes foram imersos em 0,05 M ácido cítrico $(\mathrm{pH} \mathrm{2,3)} \mathrm{por} 6 \times 10 \mathrm{~min} / \mathrm{dia}$ e armazenado em solução remineralizante. As medidas de fluoretação foram feitas como segue: grupo 1 - controle, sem fluoretação, grupo 2 - pasta fluoretada, 3 × 5 min/diariamente ( $\mathrm{NaF}, 0,15 \% \mathrm{~F})$, grupo 3 - pasta fluoretada como no grupo $2 \mathrm{e}$ aplicação de enxaguatório fluoretado $\left(\mathrm{SnF}_{2}, 0,025 \% \mathrm{~F}\right) 3 \times 5 \mathrm{~min} /$ diariamente e nos dias 1 e 3 , gel fluoretado ( $\mathrm{NaF}, 1,25 \% \mathrm{~F}$ ) por $1 \times 5$ minutos. No primeiro dia experimental, nenhuma diferença significativa foi encontrada entre os grupos. Entretanto, após 5 dias a perda mineral para o esmalte foram $147,5 \pm 18,7 \mu \mathrm{m}$ no grupo controle, $128,1 \pm 15 \mu \mathrm{m}$ no grupo $2(p<0,05)$ e $116,1 \pm 12,4 \mu \mathrm{m}$ no grupo 3 
$(p<0,001)$. Na dentina as perdas dos respectivos grupos foram: $136,7 \pm 16,4 ; 111,8 \pm$ 26,9 e 60,3 $\pm 17,8 \mu \mathrm{m}(\mathrm{p}<0,001)$. A fluoretação intensiva reduziu significativamente a progressão da erosão em esmalte, mas foi mais pronunciado seu efeito na dentina. Os resultados sugerem que pessoas com lesões de erosão deveriam usar medidas intensivas de fluoretação.

Van Rijkom et al. (2003) determinaram o efeito inibitório da erosão de aplicações tópicas de fluoreto de sódio 1\% (NaF) e tretrafluoreto de titânio 4\% $\left(\mathrm{TiF}_{4}\right)$. Dez incisivos bovinos foram selecionados e três amostras de esmalte de cada dente foram preparadas. Uma amostra de cada dente foi designada para um dos três grupos experimentais: nenhuma aplicação de flúor (controle), 4 minutos de aplicação de gel neutro de NaF 1\%; e 4 minutos de solução de $\mathrm{TiF}_{4}$ 4\%. Todos os espécimes foram repetitivamente expostos a $50 \mathrm{mM}$ de solução de ácido cítrico contendo 0,4 $m M \mathrm{CaCl}_{2}$ e 2,2mM KH $\mathrm{KO}_{4}$ a pH 3,0 por 4 dias consecutivos. A exposição ao ácido foi feita em intervalos iniciais de 2 vezes por 0,5 minuto, aumentando com os dias do experimento para 3 vezes por 2 minutos; 3 vezes por 3 minutos; 3 vezes por 4 minutos no quarto dia. A dissolução do esmalte foi determinada pelo conteúdo de cálcio liberado no ácido após a erosão usando espectroscopia de absorção atômica. Um efeito inibitório da erosão, estatisticamente significante foi encontrado para ambos os tratamentos com flúor comparado com o grupo controle após o terceiro dia. A redução da perda de cálcio, entretanto, foi maior para os espécimes tratados com $\mathrm{TiF}_{4}$ do que com NaF. A relativa redução de perda de cálcio comparado com o grupo controle permaneceu estável para o grupo de $\mathrm{TiF}_{4}$, visto que para o grupo $\mathrm{NaF}$ a redução diminuiu com o tempo acumulativo de erosão. Os autores concluíram que aplicações tópicas de $\mathrm{TiF}_{4}$ fornecem uma opção em potencial para o tratamento na prevenção da erosão. 
Ganss et al. (2004) avaliaram os efeitos do flúor na perda mineral por erosão em esmalte e dentina humanos utilizando um modelo in situ de de-remineralização. Foram feitos três tratamentos (cinco dias cada) envolvendo 4 voluntários para os espécimes de esmalte e 6 para a dentina. Os espécimes foram posicionados em aparelhos palatinos e usados durante o dia e a noite exceto durante as refeições. Foram desmineralizados extra-oralmente com 0,05 M ácido cítrico $(\mathrm{pH} 2,3)$ por 6 vezes de 5 minutos diariamente. A fluoretação foi feita com creme dental fluoretado $\left(\mathrm{SnF}_{2} / 0,14 \% \mathrm{~F}\right)$ três vezes por 5 minutos diariamente correspondendo ao grupo da fluoretação com creme dental, em outro grupo foi feita com creme dental em combinação com enxaguatório $\left(\mathrm{SnF}_{2} / 0,025 \% \mathrm{~F}\right)$ três vezes ao dia por 5 minutos e com gel (NaF/1,25\% F) nos dias 1 e 3 ao invés do creme dental, este grupo foi denominado de fluoretação intensiva. No grupo controle nenhuma fluoretação foi feita. A perda mineral foi determinada com microrradiografias longitudinais. No esmalte, a perda mineral foi de $40,7 \mu \mathrm{m}$ no controle, $18,3 \mu \mathrm{m}$ no grupo com fluoretação com creme dental e $5 \mu \mathrm{m}$ depois da fluoretação intensiva. Os respectivos valores na dentina foram $49 \mu \mathrm{m}, 35 \mu \mathrm{m}$ e 19,8 $\mu \mathrm{m}$. Todas as diferenças entre os grupos foram estatisticamente significantes. Os resultados indicaram que a fluoretação, principalmente de forma intensa, é efetiva na prevenção da perda mineral de esmalte e dentina mesmo sob severas condições erosivas.

Hughes, West e Addy (2004) investigaram se o flúor afetava a erosão causada por ácido cítrico e bebidas a base de ácido cítrico. Espécimes de esmalte obtidos de $3^{\circ}$. molares inclusos foram incluídos e polidos deixando expostos uma janela de $2 \mathrm{~mm}$ de esmalte. A avaliação da erosão foi feita com um perfilômetro. A solução de ácido cítrico utilizada foi de 0,3\% ( $\left.\mathrm{pH}_{2,15}\right)$, bebida de laranja $(\mathrm{pH} 3,4)$, "Ribena" ( $\mathrm{pH}$ 2,7) e "Baby Ribena"( $\mathrm{pH}$ 3,53). O flúor utilizado foi na forma de 
enxaguatório, mistura de creme dental/água, gel acidulado. Os espécimes foram expostos ao enxaguatório e ao creme dental por 1 minuto e ao gel acidulado por 4 minutos, em seguida foram lavados. A ação do ácido e das bebidas foi feita em seguida em imersão em 200 ml por 10 minutos com agitação. Este processo foi repetido mais duas vezes, totalizando 30 minutos de ação ácida. Após este período foram feitas novas avaliações no perfilômetro. O flúor na forma de gel acidulado foi mais eficaz na prevenção da erosão causada pelo ácido cítrico e pelas bebidas ácidas.

Willumsen et al. (2004) examinaram se o pré-tratamento do esmalte dental com uma solução de $\mathrm{SnF}_{2}$ 0,4\% poderia prevenir a dissolução do esmalte exposto a soluções de ácido clorídrico $(\mathrm{HCl}) 0,1 \mathrm{M} \mathrm{pH} \mathrm{1,2} \mathrm{ou} \mathrm{HCl} 0,01 \mathrm{M} \mathrm{pH} \mathrm{2,2.} \mathrm{O} \mathrm{esmalte} \mathrm{foi}$ pré tratado por 18 horas com solução de $0,4 \% \mathrm{SnF}_{2}$ e soluções controle de $\mathrm{NaF} 2 \%$ ou água destilada e então expostos ao $\mathrm{HCl}$ (4 minutos). O efeito foi monitorado pela microscopia eletrônica de varredura (MEV) e análise química avaliando o conteúdo de cálcio na solução após exposição ao $\mathrm{HCl}$ medido por espectrometria de absorção atômica. No pH 2,2; NaF e a água mostraram menor inibição na dissolução do esmalte, visto que $\mathrm{SnF}_{2}$ inibiu significativamente a desmineralização em todos os períodos testados. No pH 1,2, a MEV mostrou severa dissolução da superfície do esmalte independente do pré-tratamento. Como o pH do vômito é geralmente maior que $1,5, \mathrm{SnF}_{2}$ pode ser um agente interessante para o uso no tratamento e prevenção de erosão dental em pacientes com episódios de vômitos frequentes.

Vieira, Ruben e Huysmans (2005) avaliaram o efeito de 1 e $4 \%$ de gel de tetrafluoreto de titânio $\left(\mathrm{TiF}_{4}\right)$, flúor amino $(\mathrm{AmF})$ a 1 e 0,25\% e verniz fluoretado (FP) na prevenção da erosão dental. Dois grupos experimentais serviram como controle, um com nenhum pré-tratamento e outro pré-tratado com verniz sem flúor. A erosão 
dental foi simulada usando amostras de esmalte bovino submetidas a ciclos alternados de exposição ao ácido cítrico e remineralização em saliva artificial. A perda de cálcio das amostras foi quantificada por espectrofotômetro de absorção atômica e também a profundidade das erosões foi estimada pela perda de cálcio. Duas amostras de cada grupo foram analisadas com microscópio de luz confocal. A profundidade da erosão em $\mu \mathrm{m}$ após 72 minutos foi: 8,29 $\left(\mathrm{TiF}_{4}\right.$ gel 1\%); 8,27 ( $\mathrm{TiF}_{4}$ gel 4\%); 8,69 (AmF 1\%); 8,86 (AmF 0,25\%); 3,43 (FP); 14,86 (verniz sem flúor) e 9,77 (controle). Os autores concluíram que aplicações de verniz de flúor têm um efeito protetor na prevenção da erosão dental.

Hove et al. (2006) compararam o efeito protetor do tetrafluoreto de titânio $\left(\mathrm{TiF}_{4}\right)$, fluoreto de estrôncio $\left(\mathrm{SnF}_{2}\right)$ e do fluoreto de sódio $(\mathrm{NaF})$, todos com a concentração de 0,5 M de flúor, sobre o desenvolvimento de lesões de erosão em esmalte dental humano. A superfície de esmalte de três espécimes de cada dente foi tratada com as diferentes soluções fluoretadas por 2 minutos. Após o tratamento com flúor, os espécimes foram imersos em 0,01 M HCl (pH 2,0) por 2, 4 e 6 minutos para simular uma situação de refluxo gástrico. Um espécime de cada dente foi usado como controle e foi somente exposto ao ácido. A profundidade do condicionamento ácido (em milímetros) depois de 6 minutos foi avaliada utilizando interferômetro de luz branca e apresentou-se como segue: $\mathrm{TiF}_{4}$ 0,8; $\mathrm{SnF}_{2}$ 3,5; $\mathrm{NaF}$ 5,3 e 7,0 para os espécimes controle. Comparado com o controle, $\mathrm{TiF}_{4}$ protegeu a superfície do esmalte do ataque ácido quase completamente (88\%), enquanto que $\mathrm{SnF}_{2}$ reduziu a profundidade de condicionamento em $50 \%$ e o $\mathrm{NaF}$ em $25 \%$.

Hooper et al. (2007) determinaram o efeito protetor de uma pasta fluoretada experimental contendo hexametafosfato de sódio, contra um desafio erosivo em esmalte. A erosão do esmalte por suco de laranja $(\mathrm{pH} 3,8)$ foi comparada em grupos 
que utilizaram a pasta experimental, pasta padrão fluoretada e um grupo controle (água) em um modelo in vitro. A profundidade da área resultante da erosão foi medida usando um perfilômetro. Houve mais erosão significativamente nos espécimes expostos a pasta padrão e grupo controle comparada a pasta experimental. A hipótese é que o hexametafosfato de sódio forme uma camada protetora sobre a superfície que se mantém por um número de horas depois da aplicação mais que produtos fluoretados convencionais e por isso provém significante proteção contra a erosão em indivíduos susceptíveis

Magalhães et al. (2007) avaliaram o efeito de um verniz experimental de $\mathrm{TiF}_{4}$ 4\% na erosão dental. Sessenta blocos de esmalte bovino foram distribuídos aleatoriamente para cada tipo de verniz: Duraphat - D (NaF, 2,26\% F), Duofluorid F (NaF, 2,71\% F), $\mathrm{TiF}_{4}-\mathrm{T}(2,45 \% \mathrm{~F})$ e sem flúor - P. Depois da aplicação dos vernizes, os blocos foram submetidos a seis ciclagens de $\mathrm{pH}$ (Coca-Cola por 10 minutos e saliva por 50 minutos) por dia, durante 4 dias. Depois da ciclagem os dentes foram mantidos em saliva artificial por 18 horas. As alterações no esmalte foram determinadas no segundo e quarto dia, usando perfilometria (desgaste) e microdureza (\% perda mineral). As médias da microdureza no segundo e quarto dias foram, respectivamente: D (-77,26 e -88,59), F (-76,79 e -88,78), T (-88,28 e -92,04) e $P(-87,96$ e -94,15). E as médias de desgaste $(\mu \mathrm{m})$ no segundo e quarto dias foram respectivamente: $D(3,43$ e 7,56$), F(3,35$ e 7,92$), T(3,81$ e 7,69$)$ e $P(3,43$ e 7,31$)$. Os vernizes de NaF reduziram o amolecimento do esmalte mas não tiveram efeito significativo na redução do desgaste. $\mathrm{O}$ verniz de $\mathrm{TiF}_{4}$ não foi capaz de reduzir o amolecimento e o desgaste dental.

Schlueter et al. (2007) investigaran o efeito da solução de $\mathrm{TiF}_{4}$ na perda mineral em dentina e esmalte. Os espécimes foram fluoretados durante 5 minutos 
por dia com solução de $1,64 \%$ de $\mathrm{TiF}_{4}$ ou 2,2\% NaF, com pH 1,2 e então submetidos a procedimento de de-remineralização por 5 dias. A desmineralização foi realizada 6 x10 minutos por dia com ácido cítrico $(\mathrm{pH} \mathrm{2,3).} \mathrm{O} \mathrm{conteúdo} \mathrm{mineral} \mathrm{foi} \mathrm{determinado}$ por microrradiografias longitudinais. Perda mineral do esmalte foi marcantemente reduzida com ambas as soluções, mas o $\mathrm{TiF}_{4}$ foi significativamente mais efetivo que o NaF: a perda mineral no terceiro dia foi de $61,7 \mu \mathrm{m}$ no grupo do $\mathrm{NaF}$ e $34,2 \mu \mathrm{m}$ no grupo do $\mathrm{TiF}_{4}$ comparado com 121,0 $\mu \mathrm{m}$ no grupo controle. A perda mineral na dentina cessou depois das aplicações de $\mathrm{TiF}_{4}$ e $\mathrm{NaF}$. A perda mineral no quinto dia para o grupo controle foi de $61,0 \mu \mathrm{m}$, no grupo do $\mathrm{TiF}_{4}$ foi 15,4 e para o grupo do $\mathrm{NaF} 21,8$. As aplicações de $\mathrm{TiF}_{4}$ e $\mathrm{NaF}$ reduziram a perda mineral em esmalte e dentina, o que poderia abrir nova possibilidade para terapia de erosão.

Vieira et al. (2007) avaliaram in situ a eficácia do verniz fluoretado na prevenção da erosão e a combinação de erosão e abrasão por escovação dental. Onze voluntários utilizaram por três semanas, durante as horas de trabalho, dispositivos contendo duas amostras de esmalte humano como controle (C-er) e duas amostras tratadas com verniz fluoretado (FV-er). A erosão foi simulada extra oralmente 3 vezes ao dia (5 minutos) com imersão em Sprite. No fim de cada dia experimental, um controle (C-er+abr) e uma amostra fluoretada (FV-er+abr) eram escovados por 5 segundos com dentifrício fluoretado. A perda de esmalte em volume foi quantificada por um perfilômetro óptico nos dias 5,10 e 15 . Foi encontrada perda progressiva de esmalte para os grupos C-er, C-er+abr e FVer+abr, mas não para o grupo FV-er. Os valores de perda de esmalte acumulado no 15을 dia foram: C-er 5,53, C-er+abr 5,70, FV-er 0,79 e FV-er+abr 2,76. Os grupos FVer e FV-er+abr mostraram menor volume significativo de perda de esmalte do que os 
grupos C-er e C-er+abr. Os resultados indicaram que o verniz fluoretado é efetivo na redução do desgaste erosivo.

Hove et al. (2008) compararam, em um estudo in situ, o efeito protetor do $\mathrm{TiF}_{4}$ $1,5 \%, \mathrm{SnF}_{2} 3,9 \%$ e $\mathrm{NaF} 2,1 \%$ no desenvolvimento de lesões de erosão em esmalte humano. Catorze molares humanos foram divididos em 4 espécimes, montados em aparelhos orais em acrílico e usados por sete voluntários por 9 dias. Para simular 0 procedimento de prevenção para pacientes com refluxo gastro-esofágico, os espécimes foram condicionados por 2 minutos duas vezes ao dia em 0,01 $\mathrm{M} \mathrm{HCl} \mathrm{e}$ aplicações de flúor foram feitas a cada 3 dias (2 minutos). A profundidade de condicionamento e a mudança na rugosidade superficial foram medidas por interferometria de luz branca. Comparado com o controle, $\mathrm{TiF}_{4}$ e $\mathrm{SnF}_{2}$ reduziram a profundidade do condicionamento em 100\% e 91\% (p<0,001) respectivamente, e ambos os tratamentos resultaram em uma camada superficial de revestimento observável. NaF não teve efeito protetor $(p=0,46)$. Pode ser concluído que embora o $\mathrm{SnF}_{2}$ proveja significante proteção para a superfície do esmalte, $\mathrm{TiF}_{4}$ mostrou a melhor proteção contra o ataque ácido, enquanto que NaF não teve efeito protetor neste estudo.

Lussi et al. (2008) testaram o impacto de diferentes pastas de dente na prevenção da erosão. A desmineralização e remineralização do esmalte foram monitorados usando o teste de microdureza (SMH). Espécimes de esmalte humano foram tratados com dois diferentes procedimentos: 1- incubação em mistura de pasta/água (3 minutos) seguida de amolecimento em ácido (ácido cítrico 1\%, pH 4, por 3 minutos) e exposição à saliva artificial; 2- amolecimento em ácido seguido de incubação em mistura de pasta/água e exposição à saliva artificial. As seguintes pastas foram testadas: Zendium, Sensodyne Pro-esmalte, Prodent Rocket Power, 
Meridol e Signal active. Incubação nas misturas de pasta antes do desafio ácido parece ser favorável na prevenção da erosão. Nenhuma pasta testada mostrou melhor proteção estatisticamente significante do que a outra contra o ataque erosivo.

Ganss et al. (2008) avaliaram a relevância dos cátions nos diferentes compostos fluoretados para sua efetividade como agentes anti-erosivos. As soluções testadas foram: $\mathrm{SnCl}_{2}, \mathrm{NaF}, \mathrm{SnF}_{2}, \mathrm{AmF}, \mathrm{AmF} / \mathrm{NaF}$ e $\mathrm{AmF} / \mathrm{SnF}$, todas com 250 ppm F. Amostras de esmalte humano foram submetidas a procedimentos de deremineralização por 10 dias, o agente erosivo foi o ácido cítrico $(0,05 \mathrm{M}, \mathrm{pH} 2,3), 6$ vezes ao dia por 2 min seguida de imersão nas soluções fluoretadas testadas $(6 \times 2$ min). O conteúdo mineral foi monitorado por microrradiografias longitudinais. A maior perda mineral foi encontrada no grupo controle (sem aplicação de flúor) $(48,0 \mu \mathrm{m})$. A perda mineral foi praticamente inibida pelos tratamentos com $\mathrm{AmF} / \mathrm{SnF}_{2}(5.7 \mu \mathrm{m}) \mathrm{e}$ $\mathrm{SnF}_{2}(-3,8 \mu \mathrm{m})$. Grupos tratados com $\mathrm{SnCl}_{2}(17 \mu \mathrm{m})$ e $\mathrm{NaF}(13,2 \mu \mathrm{m})$ mostraram diminuição na perda mineral e $\operatorname{AmF}(41,6 \mu \mathrm{m})$ e $\operatorname{AmF} / \mathrm{NaF}(27,7 \mu \mathrm{m})$ não tiveram efeito na progressão da erosão. Os resultados indicam consideráveis diferenças entre os compostos fluoretados testados.

Magalhães et al. (2008a) avaliaram o efeito na erosão em esmalte, de um verniz experimental $\mathrm{TiF}_{4} 4 \%$ comparando-o aos vernizes comerciais e a uma solução de $\mathrm{TiF}_{4} 4 \%$. Espécimes de esmalte bovino foram distribuídos aleatoriamente nos seguintes tratamentos: verniz $\mathrm{NaF}(2,26 \% \mathrm{~F})$, verniz de $\mathrm{NaF} / \mathrm{CaF}{ }_{2}(5,63 \% \mathrm{~F})$, verniz de $\mathrm{TiF}_{4} 4 \%(2,45 \% \mathrm{~F})$, verniz sem flúor, solução de $\mathrm{TiF}_{4} 4 \%(2,45 \% \mathrm{~F})$ e controle (sem tratamento). Os vernizes foram aplicados e removidos após 6 h. A solução foi aplicada por $1 \mathrm{~min}$. Então, os espécimes foram alternadamente de-remineralizados (6 vezes/dia) por 5 dias. A desmineralização foi feita em Sprite (1 min, $3 \mathrm{ml} / \mathrm{min}$ ) e a remineralização em saliva artificial. A média diária de incremento da erosão e a 
erosão acumulada $(\mu \mathrm{m})$ foram significativamente menores para o grupo do verniz de $\mathrm{TiF}_{4}(0,30 / 0,65)$ do que para o verniz de $\mathrm{NaF}(0,58 / 1,47)$ ou o verniz de $\mathrm{NaF} / \mathrm{CaF}_{2}$ $(0,62 / 1,68)$, os quais mostraram significativamente menos erosão do que o verniz sem flúor $(0,78 / 2,05)$, a solução de $\operatorname{TiF}_{4}(0,86 / 2,05)$ e o grupo controle $(0,77 / 2,06)$. Em conclusão o verniz de $\mathrm{TiF}_{4}$ parece ser um tratamento promissor para reduzir a perda de esmalte sob condições erosivas leves.

\subsubsection{Laser}

O laser tem sido utilizado na prevenção da desmineralização do esmalte em desafios que simulam a cárie dental, apresentando bons resultados. Atualmente existem poucos trabalhos que avaliam seu efeito protetor frente ao desafio da erosão dental.

Yamamoto e Sato (1980) avaliaram o efeito do laser chaveado Nd:YAG na prevenção da cárie em esmalte. Utilizaram 60 incisivos recentemente extraídos, sem cárie. A superfície vestibular foi limpa, seca com ar, metade da superfície foi revestida com material que absorve a luz laser para ser irradiada. O protocolo utilizado foi: $100 \mathrm{KW}$, largura de pulso $100 \mathrm{mseg}$, taxa de repetição de $1 \mathrm{KHz}, 10 \mathrm{~W}$, spot size de 3,5 mm e tempo de irradiação de 0,6 a $1 \mathrm{seg}$. Depois da irradiação, os espécimes foram colocados em solução desmineralizante de hidroxietil celulose e 0,1 M ácido lático ( $\mathrm{pH} 4,5)$ por 4 dias a $37^{\circ} \mathrm{C}$ para desenvolver in vitro lesões de cárie incipientes. Depois da desmineralização os espécimes foram avaliados por microrradiografias. A microrradiografia da área do esmalte não irradiada mostrou 
radioluscência subsuperficial enquanto que a área correspondente a irradiação não mostrou desmineralização subsuperficial. Houve acentuado aumento na resistência ácida de 44 espécimes (73\%) e moderado aumento em 16 (27\%). Os pesquisadores concluíram que a exposição do esmalte ao laser inibiu efetivamente a formação de lesões de cáries. E sendo este tipo de laser de fácil manipulação e acesso a áreas da cavidade oral sem danos aos tecidos moles, este sistema parece ter aplicação clínica na cavidade oral.

Tsai et al. (2002) testaram a efetividade do tratamento com laser pulsado de $\mathrm{CO}_{2}$ e Nd:YAG na resistência ácida do esmalte humano. Trinta superfícies foram preparadas de 10 pré-molares extraídos (3 superfícies por dente). Duas superfícies de cada dente foram irradiadas com $\mathrm{CO}_{2}(1 \mathrm{~W}, 750 \mathrm{pps}, 1,33 \mathrm{~mJ} / \mathrm{pulso})$ ou $\mathrm{Nd}: Y A G$ (6 W, 50 pps, $120 \mathrm{~mJ} /$ pulso) os dois foram utilizados com a mesma fluência. Todos os espécimes foram desmineralizados em 10 ml de ácido lático por 24 ou 72 horas. Depois de 24 horas a concentração de cálcio que se dissolveu no ácido lático no grupo tratado com $\mathrm{CO}_{2}$ foi significativamente menor do que no grupo controle, enquanto que para o grupo do laser de Nd:YAG a quantidade de cálcio dissolvida não foi diferente do grupo controle. A profundidade da erosão no grupo do $\mathrm{CO}_{2}$ foi significativamente mais rasa do que no grupo do Nd:YAG avaliada em microscopia de luz polarizada. Depois de 72 horas de tratamento ácido nenhum tratamento diferiu significativamente do grupo controle. Por MEV as superfícies de esmalte tratadas com laser e erodidas apresentaram padrão tipo I e II de condicionamento, fissuras, superfícies rugosas comparadas com o grupo controle com tipo II regular de condicionamento. Concluíram que o esmalte tratado com laser de $\mathrm{CO}_{2}$ foi mais resistente ao desafio ácido do que o tratado com Nd:YAG, mas nenhum tipo de laser aumentou a resistência ácida na subsuperfície do esmalte. 
Yamada et al. (2004), observaram a superfície do esmalte e dentina irradiados com três diferentes lasers: Nd:YAG (comprimento de onda 1,06 $\mu \mathrm{m}$ ), Er:YAG $(2,94 \mu \mathrm{m})$, e $\mathrm{CO}_{2}(10,6 \mu \mathrm{m})$ através de um analisador 3D instalado no MEV e um perfilômetro sem contato. Análises de espectroscopia foram feitas com espectrofotômetro Raman nas superfícies antes e depois da irradiação. Os lasers foram aplicados em secções verticais de três molares livres de cárie que após a irradiação foram seccionados para verificar a formação de cavidades. A irradiação com Nd:YAG e $\mathrm{CO}_{2}$ na superfície do esmalte mostrou uma cor branca opaca, diferente da superfície dentinária que tornou-se preta. O Er:YAG não induziu mudanças de cor na dentina. Numerosas rachaduras associadas com o stress térmico foram observadas na dentina irradiada $\mathrm{com} \mathrm{CO}_{2}$. Análise no perfilômetro mostraram cavidades profundas no esmalte e dentina irradiados com Er:YAG. A superfície dentinária irradiada com $\mathrm{CO}_{2}$ apresentou-se a menos rugosa. Análise no espectrofotômetro Raman mostrou que a fluorescência dos dentes irradiados foi geralmente maior do que quando não irradiados. Bandas na dentina atribuída a matriz orgânica de colágeno foram perdidas após irradiação com Nd:YAG e $\mathrm{CO}_{2}$. O Er:YAG mostrou nenhum sinal de banda de carbono, condizente com a ablação dental.

Liu e Hsu (2006) avaliaram as mudanças na composição do esmalte, induzidas pelo laser, incluindo as modificações no carbonato e compostos orgânicos utilizando a espectroscopia FT-Raman. Doze janelas $(1 \mathrm{~mm} X 1 \mathrm{~mm})$ foram criadas em seis incisivos decíduos. Esta região foi caracterizada pela espectroscopia Raman (1024 nm) antes e depois da aplicação laser Er:YAG com 5,1J/cm², $2 \mathrm{~Hz}$, 5s. Foram avaliados os picos de fosfato, carbonato A e B e matéria orgânica. A intensidade do pico de carbonato tipo B diminuiu significativamente de 0,117 para $0,106(p=0,029)$, 
visto que a intensidade do carbonato tipo A permaneceu inalterado $(p=0,467)$. Em relação à matéria orgânica a intensidade do pico a $2940 \mathrm{~cm}^{-1}$ e de $1200-1600 \mathrm{~cm}^{-1}$ diminuíram significativamente. Revelando a cristalinidade do esmalte, a intensidade do fosfato na superfície irradiada parece ser inalterada. Os autores concluíram que o tratamento com laser pode promover efeito preventivo da cárie no esmalte pela redução do carbonato e modificação na matéria orgânica.

Castellan et al. (2007) avaliaram a influência do laser de Er:YAG e Nd:YAG na desmineralização do esmalte decíduo. Quarenta espécimes de esmalte decíduo humano foram distribuídos aleatoriamente em 4 grupos $(n=10)$ : G1 nenhum tratamento, G2 aplicação de fluoreto de sódio em gel acidulado por 4 minutos, G3 Er:YAG (2 Hz, $\left.60 \mathrm{~mJ}, 40,3 \mathrm{~J} / \mathrm{cm}^{2}\right)$, G4 Nd:YAG (80 mJ, $\left.10 \mathrm{~Hz}, 0,8 \mathrm{~W}\right)$. Depois dos tratamentos de superfície os espécimes foram submetidos a um desafio ácido que consistiu na imersão em solução desmineralizante (2 mM de cálcio, $2 \mathrm{mM}$ de fosfato, 0,030 ppm de flúor, $75 \mathrm{mM}$ de acetato, $\mathrm{pH} 4,3$ ) por 3 horas e em solução remineralizante por 21 horas $(\mathrm{pH} 7,0)$ repetido durante 5 dias. Em seguida foi realizado o teste de microdureza e a perda mineral foi calculada. A porcentagem de inibição de lesão foi como se segue: G2 - 59,4\%, G3 - 35,7\%, G4 - 40,4\%. Em relação à porcentagem de volume de perda mineral, não houve diferença estatística entre os grupos G2 $(444,37 \pm 146,42)$ e G3 $(441,81 \pm 207,08)$ quando comparado com grupo G1 $(281,03 \pm 134,57)$. Todos os grupos experimentais apresentaram menor perda mineral comparado com o grupo sem irradiação, mas não houve diferença estatística entre eles. 


\subsubsection{Flúor e laser}

Outro campo de interesse no controle da erosão tem sido o uso do laser e do flúor associados, com a proposta de desenvolver um novo e mais efetivo procedimento, buscando o sinergismo entre laser e flúor na redução da solubilidade do esmalte.

Goodman e Kaufman (1977) avaliaram a ação do laser de argônio associado ao fluoreto de sódio na prevenção da desmineralização do esmalte. Foram utilizados 18 incisivos extraídos e cortados ao meio no sentido vestíbulo-lingual. Uma metade foi tratada e a outra mantida como controle. Os grupos experimentais foram: 1irradiado com laser de argônio (4 W, comprimento de onda 5145 A) por 5 minutos; 2imersão em solução de fluoreto de sódio $4 \%$ e em seguida irradiação com laser argônio; 3- cobertos com mistura de flúor (NaF) e pó de esmalte e irradiados e um grupo controle sem tratamento. Os espécimes foram agitados em $3 \mathrm{ml}$ de solução de 0,2 M acetato de sódio ( $\mathrm{pH} 4,0)$ por 24 horas, sendo que a solução era trocada depois de 1 e 4 horas. Foram verificadas as quantidades de cálcio e fósforo eliminados dos espécimes na solução. Os espécimes irradiados na presença de $\mathrm{NaF}$ liberaram significativamente menos cálcio e fósforo comparado aos espécimes não irradiados. Os autores sugerem um possível papel do laser na prevenção da cárie.

Tagomori e Morioka (1989) avaliaram a combinação dos efeitos do laser de Nd:YAG e do flúor na resistência ácida do esmalte dental humano. Espécimes de esmalte foram submetidos à aplicação de solução de fluoreto de sódio (NaF 2\%) ou flúor fosfato acidulado (APF 2\%) antes ou depois da irradiação com laser. O desafio ácido foi realizado com $\mathrm{HClO}_{4}$ por 15 e 30 segundos. A aplicação de APF depois da 
irradiação causou acentuado aumento na resistência ácida do esmalte, enquanto a aplicação antes da irradiação mostrou menor efeito, sendo similar ao tratamento isolado do APF ou do laser. A aplicação de NaF causou menor resistência ácida e menor absorção de flúor do que o APF, mesmo quando o esmalte foi tratado com laser.

Boari e Zezell (2001) avaliaram o efeito na prevenção de cárie em fóssulas e fissuras do laser de Nd:YAG associado com flúor fosfato acidulado em crianças e adolescentes. Trinta e três pacientes foram selecionados, com idade variando entre 7 e 15 anos, com os molares e/ou pré-molares recém erupcionados, sem lesões de cárie nos dois lados da arcada. Os dentes do lado esquerdo foram mantidos como controle. A face oclusal dos dentes do lado direito foram revestidos com pigmento preto (carvão + água/álcool) para aumentar a absorção do laser de Nd:YAG. Os parâmetros utilizados foram: $60 \mathrm{~mJ} / 10 \mathrm{~Hz}$, fluência $84,9 \mathrm{~mJ} / \mathrm{cm}^{2}$, diâmetro de fibra de $300 \mu \mathrm{m}$. Este procedimento foi repetido por 3 vezes. Depois da irradiação laser, os dentes dos dois lados foram cobertos com flúor por 3 minutos. Os resultados clínicos finais foram avaliados após um ano do tratamento. $27 \%$ dos pacientes apresentavam cárie nos dentes controles e 10\% apresentavam cárie incipiente nos dentes tratados com laser mais flúor.

Tepper et al. (2004) avaliaram o efeito do tratamento com laser $\mathrm{CO}_{2}$ imediatamente após aplicação de solução de flúor amino no esmalte. Eles supunham que tal tratamento aumentaria a absorção de flúor, e reduziria a taxa de dissolução e alterações térmicas superficiais do esmalte. Quarenta secções de esmalte humano foram divididos em 4 grupos $(n=10)$ : (1) sem tratamento, (2) exposto a solução de flúor amino $1 \%$ por 15 segundos sem irradiação, (3) irradiado por 15 segundos com laser de $\mathrm{CO}_{2}(10,6 \mu \mathrm{m}, 2 \mathrm{~W})$, (4) irradiado por 15 segundos 
através da solução de flúor aplicada imediatamente antes. A absorção de flúor foi determinada com um eletrodo íon-seletivo. Para a determinação da resistência ácida, outros 40 fragmentos foram tratados com o protocolo acima. A resistência ácida foi determinada pela quantidade de cálcio liberada após imersão em ácido lático através de espectroscopia de absorção atômica. Alterações na superfície após a irradiação foram observadas em MEV. A irradiação do laser através da solução de flúor levou ao aumento significativo do conteúdo de flúor na superfície do esmalte comparado ao tratamento somente com flúor ou laser. Tratamento com laser com ou sem flúor resultou em aumento da resistência ácida do esmalte. Menores alterações superficiais foram observadas em MEV nos espécimes irradiados através da solução de flúor comparado com aqueles com somente irradiação laser.

Vlacic, Meyers e Walsh (2007) investigaram a ação da fluorterapia ativada pelo laser na proteção do esmalte dental ao amolecimento em resposta ao desafio erosivo e examinaram a alteração de temperatura intra-pulpar durante a aplicação do laser. Foram utilizadas superfícies vestibulares e linguais de pré e molares. Após a aplicação de gel neutro de fluoreto de sódio $(1,23 \%)$ as superfícies foram irradiadas com lasers de 488, 514.5, 532, 633, 670, 830 e 1064 nm de comprimento de onda (fluência de $15 \mathrm{~J} / \mathrm{cm}^{2}$; spot size $5 \mathrm{~mm}$ ), então expostos ao desafio erosivo com 1,0 M HCl por 5 minutos. A dureza Vicker's foi avaliada antes da aplicação do flúor e após o desafio erosivo. Todos os comprimentos de onda examinados ofereceram efeito protetor contra a erosão em comparação ao grupo controle onde não foi irradiado e nem aplicado flúor. O comprimento de onda em 633 nm (InGaAsP diode laser) foi o que apresentou melhor resultado. Não houve aumento significativo da temperatura intra-pulpar, com a maior variação sendo de $1,45^{\circ} \mathrm{C}$. Os autores 
concluíram que houve efeito protetor da fluorterapia asssociada ao laser na erosão do esmalte dental.

Bevilácqua et al. (2008) avaliaram a resistência à desmineralização e a incorporação de flúor no esmalte irradiado com Er:YAG. Cento e dez dentes bovinos foram selecionados e divididos em 8 grupos: sem irradiação, condicionado com ácido fosfórico a 37\% e espécimes irradiados com Er:YAG em várias fluências $\left(31,84 \mathrm{~J} / \mathrm{cm}^{2}, 25,47 \mathrm{~J} / \mathrm{cm}^{2}, 19,10 \mathrm{~J} / \mathrm{cm}^{2}, 2,08 \mathrm{~J} / \mathrm{cm}^{2}, 1,8 \mathrm{~J} / \mathrm{cm}^{2}\right.$ e $\left.0,9 \mathrm{~J} / \mathrm{cm}^{2}\right)$. A aplicação de flúor fosfato acidulado foi realizada após os tratamentos. Todos os espécimes foram imersos em $2 \mathrm{ml}$ de acetato acético $(2 \mathrm{M}, \mathrm{pH} 4,5)$ por 8 horas, e os íons flúor, cálcio e fósforo dissolvidos foram analisados por espectrometria de absorção atômica. Os grupos do ácido fosfórico e fluência de $31,84 \mathrm{~J} / \mathrm{cm}^{2}$ apresentaram a menor dissolução de cálcio e fósforo. A maior incorporação de flúor foi observada nas fluências $1,8 \mathrm{~J} / \mathrm{cm}^{2}$ e $0,9 \mathrm{~J} / \mathrm{cm}^{2}$. A combinação Er:YAG e aplicação tópica de flúor mostrou efeito benéfico na resistência ácida no esmalte e um aumento da incorporação de flúor. Entretanto, estes efeitos dependeram da fluência aplicada sobre a superfície de esmalte.

Sobral et al. (2009) avaliaram a efetividade do laser de Nd:YAG e sua associação com flúor fosfato acidulado na prevenção da erosão e perda de estrutura do esmalte quando submetido a regimes de erosão/abrasão e somente erosão. Duas metodologias foram testadas: uma avaliando a perda de peso de fragmentos de esmalte bovino após erosão/abrasão e a outra avaliou a microdureza de esmalte humano após erosão. Os espécimes foram submetidos a quatro diferentes tratamentos: nenhum tratamento (controle), 4 minutos de aplicação de flúor; irradiação com laser de Nd:YAG (1W, $\left.100 \mathrm{~mJ}, 10 \mathrm{~Hz}, 141,5 \mathrm{~J} / \mathrm{cm}^{2} / 125 \mathrm{~J} / \mathrm{cm}^{2}\right)$; e irradiação com laser Nd:YAG + 4 minutos de flúor. Em seguida os espécimes 
bovinos foram imersos em ácido cítrico (2\%) por 30 minutos e depois, submetidos a 5000 ciclos de escovação. Os espécimes de esmalte humano foram imersos em ácido cítrico por 90 minutos. A irradiação com Nd:YAG + aplicação de flúor, tanto para os espécimes de esmalte humano quanto para o bovino, foi estatisticamente mais efetiva na prevenção da erosão e desgaste do esmalte que os demais tratamentos avaliados. 


\section{PROPOSIÇÃO}

O objetivo deste trabalho foi comparar in vitro o efeito erosivo de uma bebida ácida (ácido extrínseco) e do suco gástrico (ácido intrínseco) sobre o esmalte dental. Foram avaliados também métodos de controle da ação erosiva de um ácido sobre o esmalte dental. 


\section{MATERIAL E MÉTODOS}

O presente estudo foi conduzido após aprovação do Comitê de Ética em Pesquisa da Faculdade de Odontologia da Universidade de São Paulo (CEP/FOUSP 119/06, Anexo A) e do Hospital Universitário da Universidade de São Paulo (HUUSP) (CEP/HU 689/06, Anexo B).

\subsection{Delineamento Experimental}

- Primeira Fase: obtenção do suco gástrico. Determinação do pH e realização da titulação dos ácidos avaliados. Comparação do potencial erosivo do ácido cítrico (suco de laranja) e do ácido gástrico sobre esmalte dental humano.

- Segunda Fase: avaliação de métodos de controle da ação erosiva do ácido que se mostrou mais lesivo à estrutura do esmalte na primeira fase.

\subsection{Seleção dos Dentes}

Foram selecionados 20 terceiros molares humanos hígidos que não foram expostos à cavidade bucal (inclusos), doados pelo Banco de Dentes da Faculdade 
de Odontologia da Universidade de São Paulo. Os dentes foram mantidos em água destilada deionizada a $4^{\circ} \mathrm{C}$ até sua utilização.

Os dentes foram limpos com curetas periodontais, seguida de uma profilaxia com escova de Robson e pedra-pomes. Posteriormente foram examinados sob lupa estereoscópica (SZ-PT/SZ40, Olympus, Tóquio, Japão) com aumento de 10x, descartando aqueles com trincas ou anomalias de estrutura.

\subsection{Primeira Fase}

\subsubsection{Preparo da amostra}

As coroas de cinco dentes foram seccionadas das raízes em uma cortadeira metalográfica (Labcut Modelo 1010 Extec, EUA) e então seccionadas verticalmente separando as faces vestibular e lingual, que foram novamente seccionadas verticalmente para obter quatro espécimes de esmalte de cada coroa (Figura 4.1). Em seguida a superfície do esmalte foi lixada em uma politriz (Ecomet 3, Buehler, Lake Bluff, IL, EUA) com lixas de granulação 400, 600, 800, 1000, 1200 e finalizando com polimento com um feltro (Buehler, Lake Bluff, IL, EUA). Este procedimento foi realizado para planificar a superfície do esmalte para realização das leituras de espectroscopia Raman, o desgaste foi mínimo e sempre tomando o cuidado de não expor dentina. 

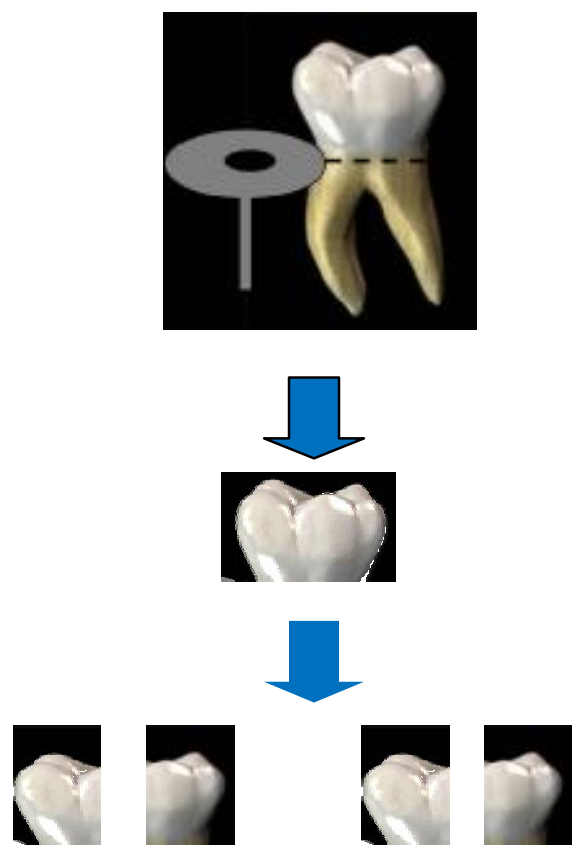

Figura 4.1 - Corte do dente e obtenção de quatro fragmentos

A superfície do espécime foi revestida com esmalte cosmético (Risqué, Niasi, São Paulo, Brasil) ácido resistente deixando descoberto apenas uma janela de 3×3 mm sobre a superfície polida do esmalte (Figura 4.2).

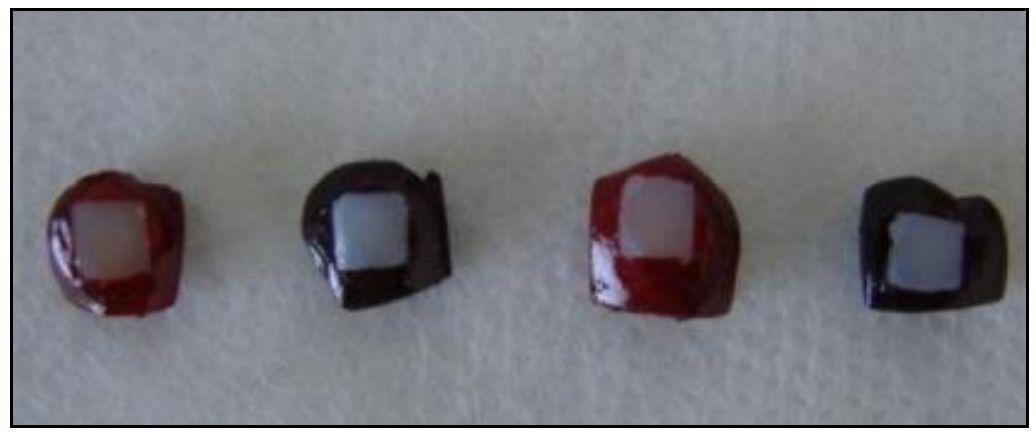

Figura 4.2 - Espécimes de esmalte recobertos com esmalte cosmético formando janela de exposição 
Vinte espécimes de esmalte resultantes da secção das coroas foram divididos em dois grupos $(n=10)$ para ação do suco de laranja e do suco gástrico, respectivamente, de forma que um fragmento da face vestibular e um da face lingual de cada dente fossem distribuídos para cada um dos grupos. Os espécimes designados para o grupo do suco de laranja foram revestidos com esmalte vermelho e os do grupo do suco gástrico foram revestidos com esmalte preto (Figura 4.2).

As composições do suco gástrico e suco de laranja estão descritas na tabela 4.1 .

Tabela 4.1 - Composição das fontes ácidas avaliadas

\begin{tabular}{c|l}
\hline \multicolumn{1}{c|}{ Fonte ácida } & \multicolumn{1}{c}{ Composição } \\
\hline \multirow{3}{*}{ Suco gástrico* } & HCl livre \\
Componentes inorgânicos: Cl, Na, Ca, P, K \\
Enzimas e precursores: pepsina, catesina, renina, \\
lipase \\
Mucina (mucoproteínas) \\
Bicarbonato (na ausência de ácidos)
\end{tabular}

*Vilela (1961), Cantarou e Schepartz (1968) e Mountcastle (1978)

** Informações do fabricante 


\subsubsection{Obtenção do suco gástrico}

Para simular a etiologia com fonte intrínseca de erosão dental foi utilizado o suco gástrico. Este foi coletado durante exame de endoscopia de pacientes que se queixavam de problemas gástricos como azia e queimação. Os pacientes foram orientados quanto aos objetivos da pesquisa e os procedimentos de coleta e solicitado a aprovação do termo de consentimento livre e esclarecido (Anexo C).

A coleta foi realizada no Hospital Universitário (HU - USP), no Departamento de Endoscopia. O suco gástrico foi aspirado durante o exame de endoscopia, utilizando o frasco "bronquinho" (Figura 4.3) para coletar o líquido e em seguida armazenado em frascos de vidro âmbar e acondicionado a $-7^{\circ} \mathrm{C}$. A coleta foi realizada no período de 3/05/2007 a 5/07/2007.

O suco gástrico foi coletado de quarenta e cinco pacientes (29 mulheres e 16 homens) com idade variando de 18 à 76 anos. O conteúdo individual coletado variou de 5 à $70 \mathrm{ml}$ totalizando $2800 \mathrm{ml}$. Este total ou "pool" representou a fonte ácida de origem intrínseca.

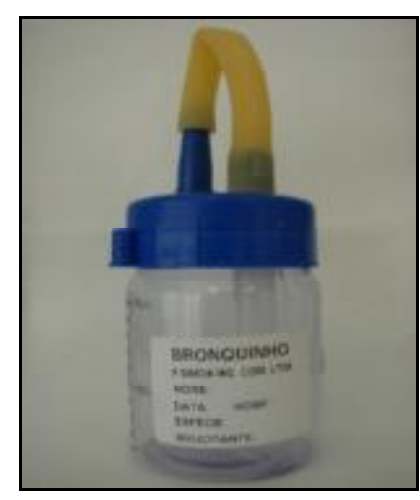

Figura 4.3 - Frasco "bronquinho" para coleta de suco gástrico 
4.3.3 Obtenção do suco de laranja

O suco de laranja foi utilizado para simular uma fonte extrínseca de erosão dental. Foi utilizado um suco industrializado para homogeneização da amostra.

O suco selecionado foi o de nome comercial Mais (Minute Maid, Coca-Cola Company Mais Indústria de Alimentos, Linhares, ES, Brasil, lote P180408) por apresentar em sua composição basicamente suco concentrado de laranja (Figura 4.4).

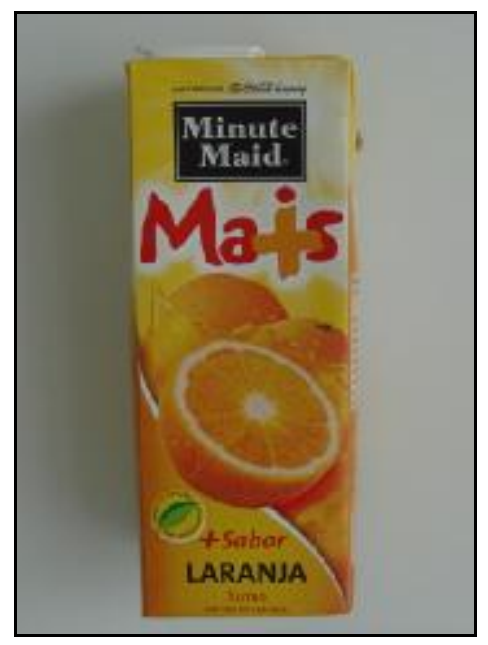

Figura 4.4 - Suco de laranja utilizado como fonte ácida de origem extrínseca

4.3.4 Determinação do pH e titulação dos ácidos

O pH do suco de laranja e do "pool" de suco gástrico coletado foi avaliado em um medidor de pH (Quimis Aparelhos Científicos Ltda, Diadema, SP, Brasil), 
avaliando $20 \mathrm{ml}$ de cada solução sob leve agitação. A titulação foi calculada pelo acréscimo de hidróxido de sódio $(2 \mathrm{M})$ necessário para neutralizar o ácido (atingir pH 7).

\subsubsection{Desafio erosivo}

Para simular as condições bucais durante o consumo de bebidas erosivas e de episódios de refluxo gastro-esofágico os espécimes de esmalte foram submetidos a ciclos alternados de desmineralização e remineralização em saliva artificial (Saliform/Fórmula \& Ação). A composição da saliva empregada está apresentada no quadro 4.1.

Saliva Artificial (Fórmula \& Ação)

Composição: Cloreto de potássio, sódio, magnésio, cálcio; fosfato de potássio, fluoreto de sódio, tiocianato de potássio, sorbitol, metilparabeno, mentol, água deionizada

Quadro 4.1 - Composição da saliva artificial

Um ciclo completo consistiu nos seguintes passos: (1) 5 minutos em $3 \mathrm{ml}$ de solução desmineralizadora (suco de laranja ou suco gástrico), (2) enxague com água destilada (3 ml), (3) armazenagem em saliva artificial por 3 horas (Figura 4.5). $\mathrm{O}$ ciclo foi repetido quatro vezes ao dia por 14 dias. 
Cada espécime foi imerso na solução desmineralizante em tubos de vidro individualizados, sob leve agitação em agitador magnético (Biomixe, Co, China), em temperatura ambiente. A solução foi renovada a cada ciclo.

No período de repouso entre um dia e outro da ciclagem os espécimes eram mantidos em saliva artificial em temperatura ambiente.

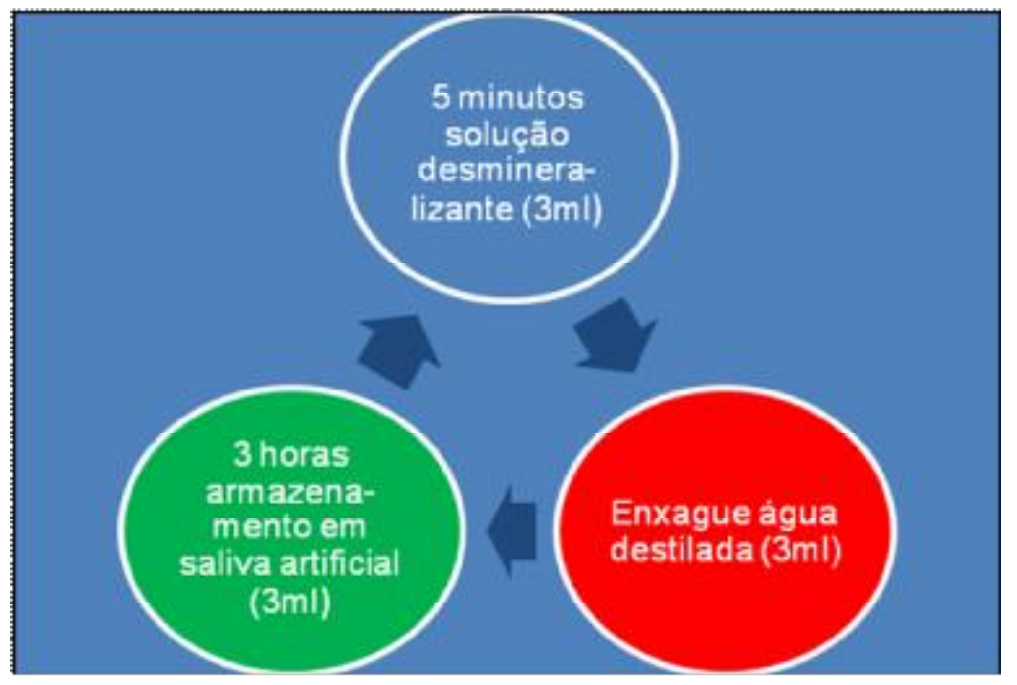

Figura 4.5 - Ciclo de desmineralização-remineralização

4.3.6 Determinação do potencial erosivo das fontes ácidas

O potencial erosivo do suco de laranja e do suco gástrico foi avaliado analisando o conteúdo mineral perdido pelos espécimes de esmalte após os 14 dias do desafio erosivo, empregando-se dois métodos: espectrometria de emissão atômica e espectroscopia FT-Raman. 
Espectrometria de Emissão Atômica

A perda de cálcio após exposição ácida foi determinada com o espectrômetro de emissão atômica (Spectroflame Modula, Spectro Co, Alemanha) (Figura 4.6 A). A análise foi feita nas soluções desmineralizantes (ácidos) após utilização na ciclagem combinadas com a água destilada usada para lavar os espécimes. Também foram analisados os ácidos "brancos", ou seja, sem o contato com os espécimes, para que servissem como padrão de referência do conteúdo original de cálcio presente nestes ácidos.

Todo o suco gástrico e suco de laranja utilizado para a desmineralização dos espécimes, juntamente com a água destilada da lavagem, foram armazenados em frascos de vidro âmbar e mantidos refrigerados até o término da ciclagem para a avaliação do cálcio presente na solução.

O espectrômetro de emissão atômica é um equipamento utilizado para leitura qualitativa e quantitativa de elementos químicos. Envolve radiação eletromagnética (luz) que é emitida por átomos da amostra. Geralmente inclui emissão de radiação eletromagnética por átomos carregados, ou íons.

A solução coletada era aspirada e transportada até um nebulizador, já no interior do espectrofotômetro, para que a amostra no estado líquido fosse transformada em um gás. Este gás era então ionizado.

Uma vez que os átomos ou íons estão no estado excitado (ionizados) podem decair para estados mais baixos através de energia de transição térmica ou radioativa (emissão) (CECCHINI, 2001). Esta energia tem comprimentos de onda que são característicos e específicos de cada elemento químico e a intensidade da linha do espectro de emissão é proporcional à concentração do elemento analisado. 


\section{Espectroscopia FT-Raman}

Foi utilizado também o espectrômetro FT-Raman (Bruker RFS 100, Bruker Optics, Alemanha) (Figura 4.6B) para avaliar o conteúdo mineral inicial e final dos espécimes. Espectroscopia FT-Raman é uma técnica analítica rápida que determina a estrutura e composição química dos espécimes (SAKOOLNAMARKA et al., 2005). Ela fornece informações químicas baseadas nas vibrações moleculares dos espécimes (SCHULZE et al., 2004). O componente inorgânico é representado por picos das bandas de fosfatos (comprimento de onda de $960 \mathrm{~cm}^{-1}$, apatita), carbonato $\left(1045 ; 1072 \mathrm{~cm}^{-1}\right)$ e o componente orgânico é representado pelo pico $1668 \mathrm{~cm}^{-1}$, amida.

Análises das alterações nas intensidades dos picos permitem que o conteúdo químico dos tecidos seja diferenciado.

Para a espectroscopia FT-Raman, os espécimes foram colocados no posicionador de espécimes do equipamento e as lentes IR354 coletaram a dispersão de radiação em torno de $180^{\circ}$. Os espectros dos espécimes foram obtidos utilizandose o equipamento FT-Raman Spectrometer com um detector de diodo refrigerado por $\mathrm{N}_{2}$ líquido. Para a excitação do espectro, foi utilizada a linha $\lambda=1064 \mathrm{~nm}$ focada de um equipamento de laser de Nd:YAG ar-refrigerado. A maior potência de laser incidente sobre as superfícies das amostras foi de aproximadamente $70 \mathrm{~mW}$ e a resolução do espectro foi de $4 \mathrm{~cm}^{-1}$. Os espectros FT-Raman foram obtidos realizando-se 300 varreduras com frequência explorada variando de 800 a $1800 \mathrm{~cm}$ 1. Os espectros foram obtidos antes e após o desafio erosivo focando a região central da janela de exposição de 3×3mm de esmalte do espécime. 
A avaliação das mudanças nas estruturas minerais e orgânicas foi executada comparando-se a razão da área sob os picos de 1045, 1072 (carbonato), e 1668cm (amida) com a área sob o pico de $960 \mathrm{~cm}^{-1}$ (fosfato).
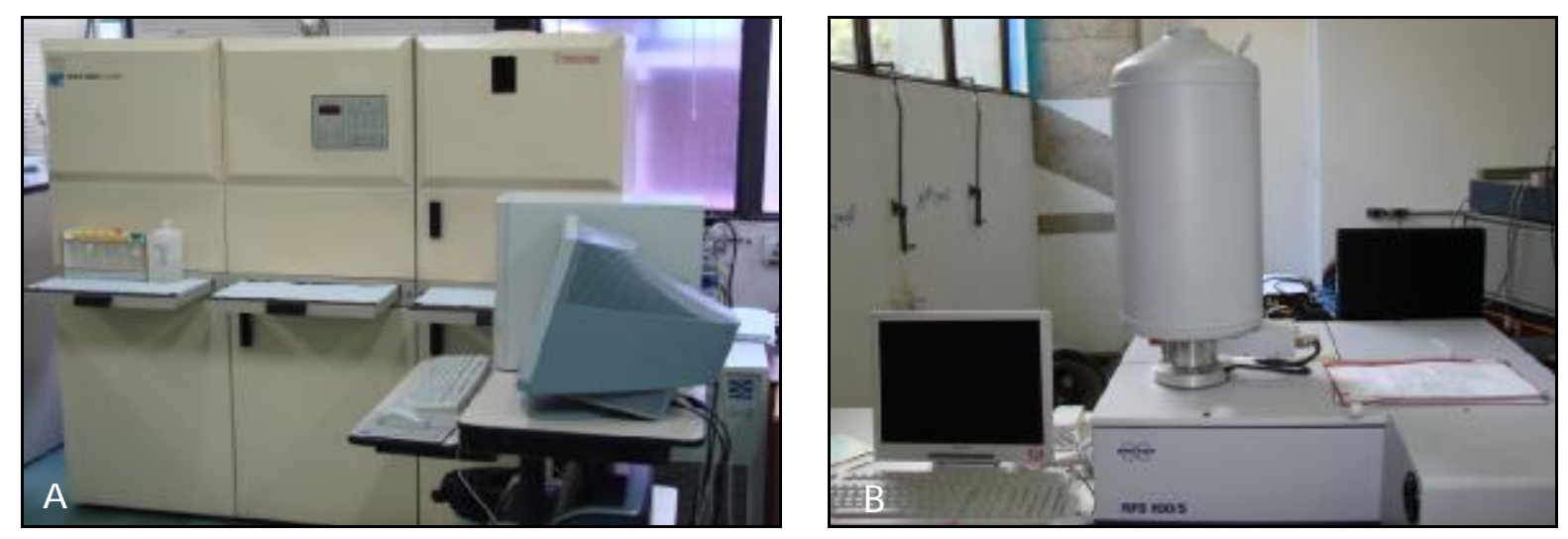

Figura 4.6 - Aparelhos utilizados para avaliação da perda de conteúdo mineral dos espécimes. AEspectrômetro de emissão atômica. B- Espectrômetro FT-Raman

4.3.7 Análise em microscopia eletrônica de varredura

Para análise qualitativa das alterações estruturais do esmalte submetido ao desafio erosivo, um espécime de cada grupo foi preparado para ser avaliado em microscópio eletrônico de varredura (JEOL JSM-5600 LV, Tokyo, Japão).

Cada espécime foi preparado para análise em Microscópio Eletrônico de Varredura (MEV) da seguinte maneira: lavagem em ultrassom com acetona por 10 minutos, imersão em solução de glutaraldeído $2,5 \%$ por 4 horas, seguido de 3 lavagens de 5 minutos cada com Tampão Fosfato $0,1 \mathrm{M}$, desidratação em concentrações ascendentes de etanol: 30\% (10 minutos), 50\% (10 minutos), 70\% (10 minutos), 90\% (10 minutos), 96\%(10 minutos) e 100\% (20 minutos). Após a 
desidratação, os espécimes foram submetidos a um processo de secagem química com o objetivo de minimizar as alterações da superfície a ser examinada, favorecendo a deposição subsequente da camada de ouro, a fim de tornar o campo a ser visualizado mais nítido. Para a secagem química, os espécimes foram mantidos por 20 minutos em uma solução de HMDS. Todos estes procedimentos foram realizados no interior de uma capela de exaustão de gases.

Em seguida, foram colados em stubs, onde a superfície de cada espécime foi coberta com uma fina camada de ouro (aproximadamente 10-12 $\mathrm{nm}$ de espessura). As observações através da análise em MEV foram então realizadas em um Microscópio Eletrônico de Varredura com 15 kV e aumento de 400 e 2000 ×.

\subsection{Segunda Fase}

Após a conclusão da primeira fase, foi dado continuidade ao experimento avaliando métodos de controle da erosão dental em esmalte.

\subsubsection{Preparo da amostra}

Para esta fase do experimento foram selecionados 10 dentes e preparados da mesma forma da primeira fase, resultando em 40 fragmentos de esmalte. Os 
espécimes foram divididos de forma que os fragmentos do mesmo dente fossem distribuídos aleatoriamente para os diferentes grupos.

Os espécimes foram divididos em 4 grupos de acordo com o método de controle utilizado como mostra a tabela 4.2.

Tabela 4.2 - Distribuição dos espécimes de acordo com o método de controle da erosão

\begin{tabular}{l|l}
\hline Grupos & Métodos de controle da erosão \\
\hline G1 $(n=10)$ & Gel flúor fosfato acidulado (APF 1,23\%) \\
\hline G2 $(n=10)$ & Laser Nd:YAG (100 mJ, 1 W, 10 Hz,) \\
\hline G3 $(n=10)$ & Gel APF 1,23\% - laser Nd:YAG \\
\hline G4 $(n=10)$ & Laser Nd:YAG - gel APF 1,23\% \\
\hline
\end{tabular}

4.4.2 Métodos de controle da erosão

Os métodos de controle da erosão empregados neste trabalho estão relacionados na tabela 4.2 . Estes procedimentos foram realizados 1 hora antes do desafio erosivo descrito na primeira fase e após estes procedimentos os espécimes foram armazenados em saliva artificial.

Para o grupo 1 (G1), o gel de flúor fosfato acidulado $(1,23 \%$ íons $F$, gel de ácido fosfórico 0,1 molar, pH 5,3, Dentsply Indústria e Comércio Ltda, Petrópolis, RJ, Brasil) (Figura 4.7A) foi aplicado diretamente sobre a superfície do esmalte por 4 minutos e após este período retirado com uma gaze seca. 
No grupo 2 (G2), a superfície dos espécimes foi coberta com um pigmento para melhor absorção do laser (carvão triturado + água). A irradiação das superfícies de esmalte foi realizada no Laboratório Especial de Laser em Odontologia (LELO), da Faculdade de Odontologia da Universidade de São Paulo usando um laser de neodímio; ítrio, alumínio, granada (Nd:YAG, Pulse Master 1000 IQ, American Dental Technology, San Carlos, USA) (Figura 4.7B) comprimento de onda 1,064 $\mu \mathrm{m}$. Foi aplicado com os parâmetros 100 mJ, 1 W e 10 Hz; utilizando fibra óptica de 300 um de forma perpendicular à superfície, com contato, durante trinta segundos, varrendo toda a superfície no sentido horizontal e vertical. A densidade de energia empregada foi de $141,54 \mathrm{~J} / \mathrm{cm}^{2}$.

No grupo 3 (G3), o flúor foi aplicado como descrito no grupo 1 e em seguida foi realizada a irradiação da superfície com o laser de Nd:YAG como no grupo 2.

Para grupo 4 (G4), o laser foi aplicado como descrito acima (G2) e em seguida foi aplicado o flúor como no grupo 1.
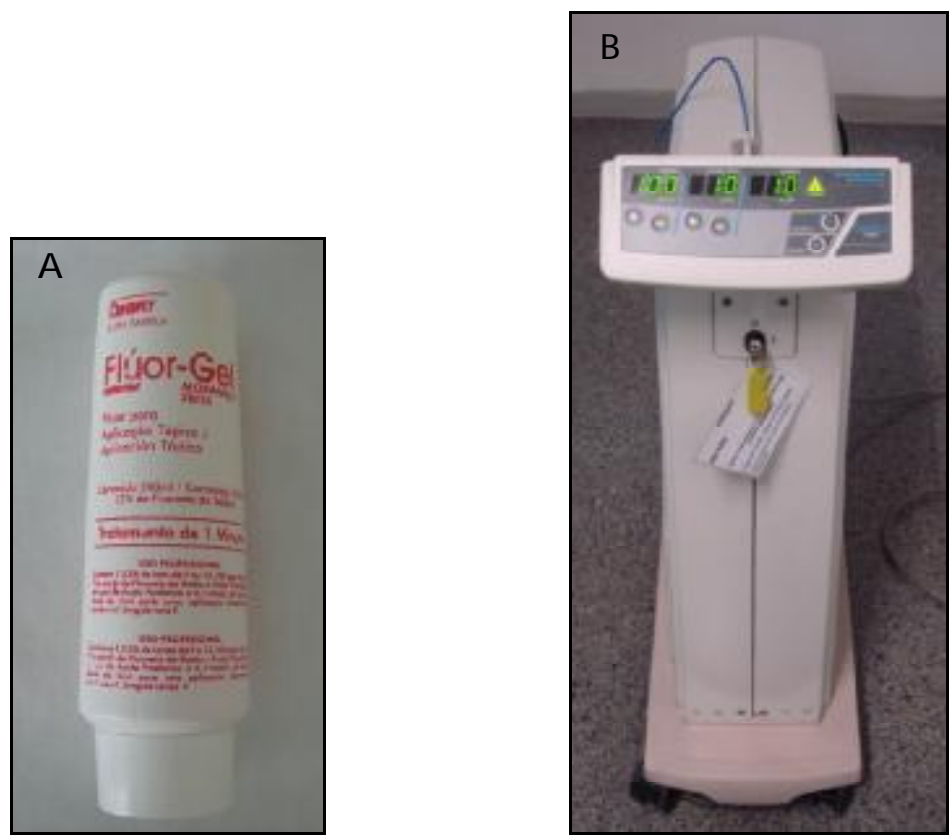

Figura 4.7 - Métodos de controle da erosão utilizados. A- Flúor. B- Laser Nd:YAG 


\subsubsection{Desafio erosivo}

Após a aplicação dos métodos de controle da erosão e armazenamento em saliva artificial por 1 hora, os espécimes foram submetidos ao desafio erosivo.

$\mathrm{Na}$ primeira fase do experimento ficou constatado que a fonte ácida representada pelo suco gástrico apresentou potencial erosivo maior que o suco de laranja. Por isso na segunda fase para avaliação dos métodos de controle da erosão em esmalte foi utilizado o ácido clorídrico a 0,01 M e pH 2,2 para simular o suco gástrico.

O ciclo de desmineralização - remineralização foi semelhante ao descrito na primeira fase.

4.4.4 Avaliação dos métodos de controle da erosão

A avaliação foi feita analisando a perda de cálcio dos espécimes utilizando a espectrometria de emissão atômica descrita anteriormente (primeira fase).

Também foi realizada a avaliação da rugosidade superficial antes e após o desafio erosivo.

Foi avaliada a rugosidade superficial de cada espécime utilizando um equipamento com ponta avaliadora de 2 micrômetros ( $\mu \mathrm{m})$ (Surftest SJ 201-P, Mitutoyo Corporation, Kawasaki, Japão) (Figura 4.8). A rugosidade superficial foi caracterizada pelo parâmetro Ra (rugosidade média), cut-off 0,25 mm, comprimento 
de leitura 1,25 $\mathrm{mm}$. Foram realizadas três leituras em cada espécime e a média dessas leituras foi considerada a rugosidade superficial inicial.

Após o desafio erosivo o esmalte cosmético foi removido da superfície dos espécimes e a ponta avaliadora do equipamento percorreu parte da região do esmalte polido que não foi exposto ao ácido, a borda da lesão formada pela erosão e a parte interna da lesão. Foram feitas três leituras e a média foi considerada como rugosidade superficial final.

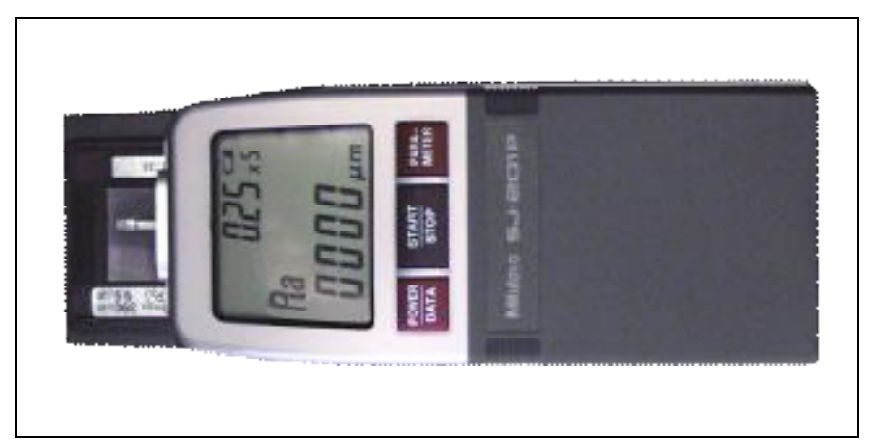

Figura 4.8 - Rugosímetro

4.4.5 Análise em microscopia eletrônica de varredura

Para análise qualitativa dos espécimes, um espécime de cada grupo foi preparado para ser avaliado em microscópio eletrônico de varredura (JEOL JSM5600 LV, Tokyo, Japão) conforme detalhado na primeira fase.

Na figura 4.9 foi esquematizada a metodologia empregada na segunda fase para avaliação dos métodos de controle da erosão investigados. 


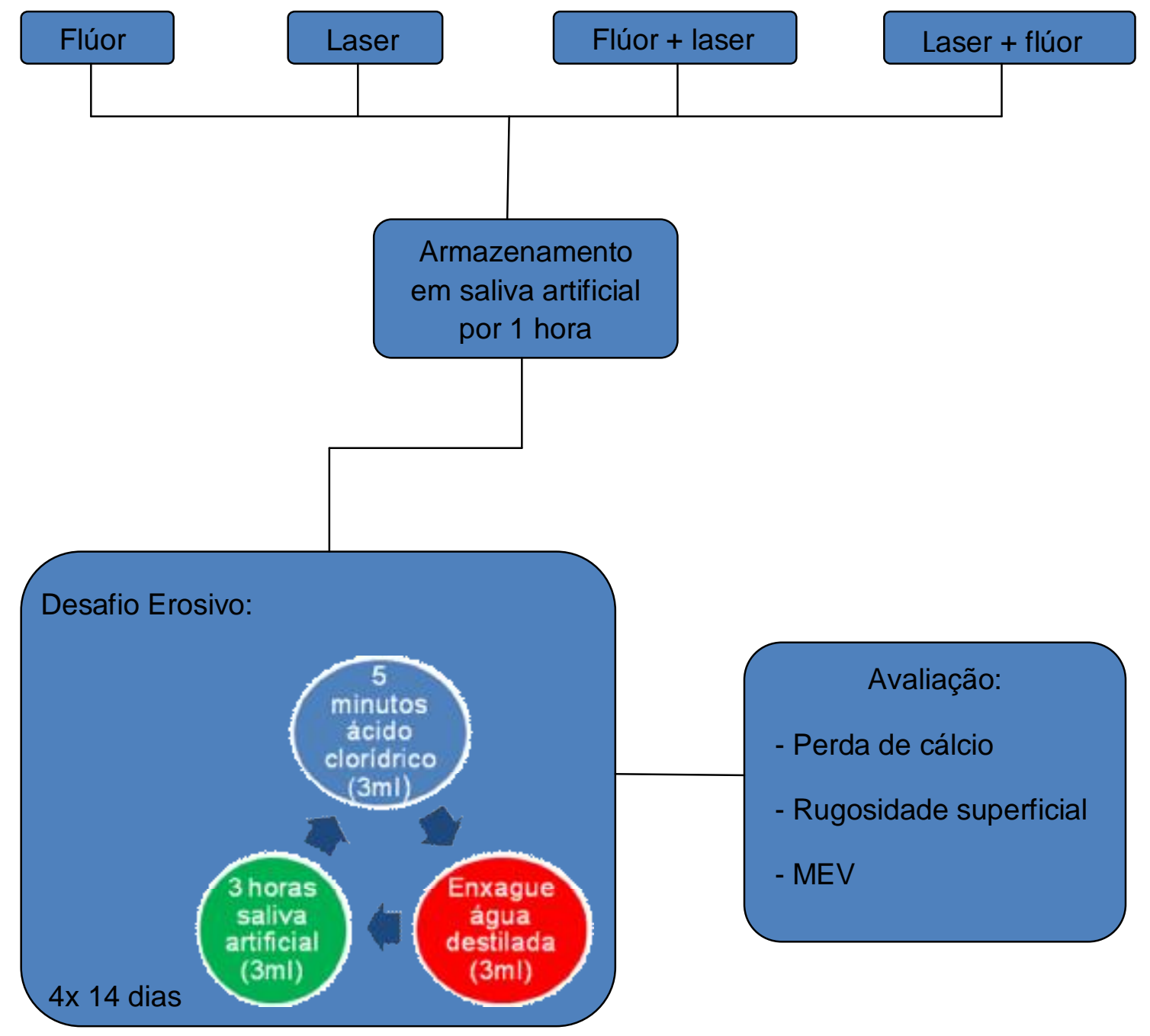

Figura 4.9 - Esquema da metodologia da segunda fase do experimento

\subsection{Análise estatística}

Os dados numéricos obtidos foram submetidos à análise estatística condizente com a distribuição amostral utilizando o programa BioEstat 5.0 e GMC. 


\section{RESULTADOS}

Os resultados serão apresentados conforme a sequência de execução mostrada nos Materiais e Métodos.

\subsection{Resultados da Primeira Fase}

5.1.1 Valores de pH e titulação dos ácidos

Os valores do pH das soluções ácidas avaliadas estão representados na tabela 5.1. O suco gástrico apresentou $\mathrm{pH}$ mais baixo do que o suco de laranja.

Tabela 5.1 - Valores de pH do suco de laranja e suco gástrico

\begin{tabular}{c|c}
\hline Soluções ácidas & $\mathbf{p H}$ \\
\hline Suco de laranja & 3,67 \\
\hline Suco gástrico & 1,61 \\
\hline
\end{tabular}

Para a realização da titulação foram acrescentados $\mathrm{NaOH}(2 \mathrm{M})$ à $20 \mathrm{ml}$ de cada um dos ácidos. Para o suco de laranja foram necessários $0,65 \mathrm{ml}$ de $\mathrm{NaOH}$ (2M) para neutralizar o ácido enquanto que para o suco gástrico foram necessários $0,5 \mathrm{ml}$ (Figura 5.1). 


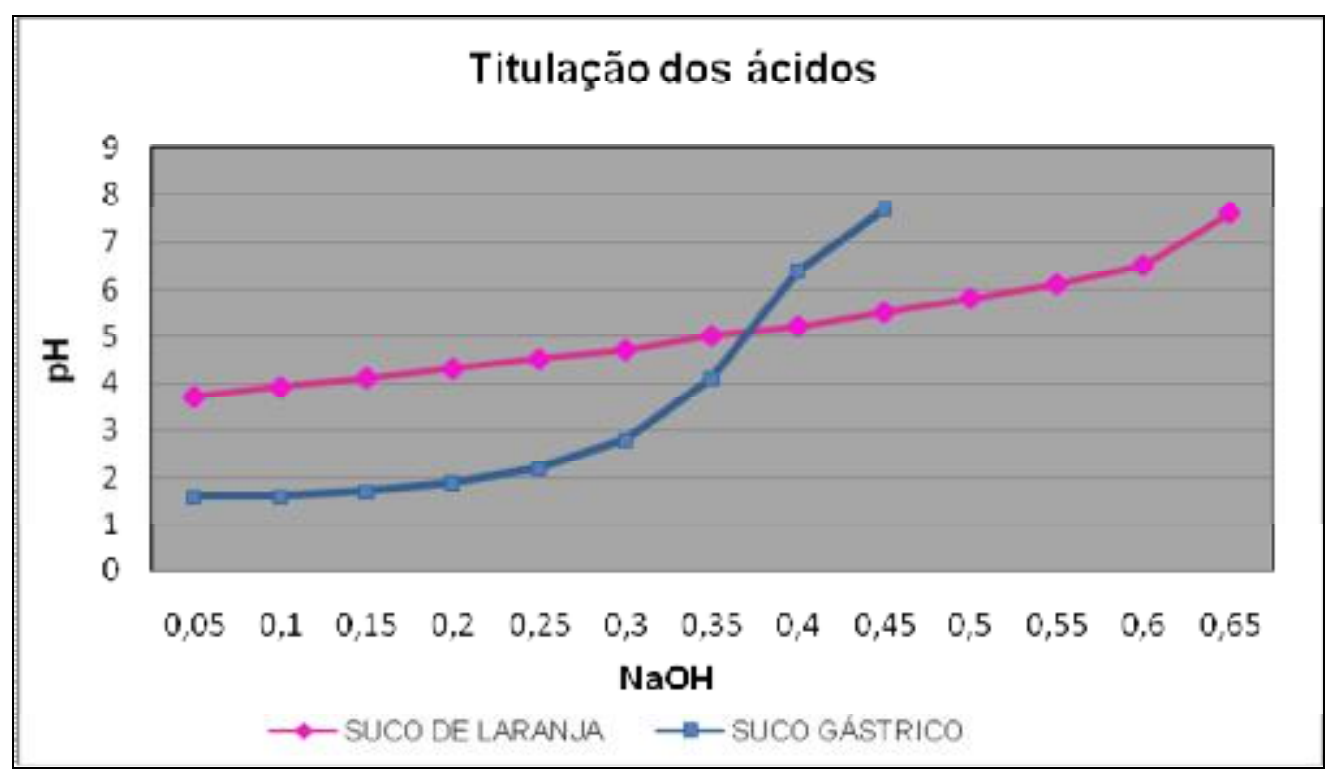

Figura 5.1 - Gráfico da titulação do suco de laranja e suco gástrico

\subsubsection{Espectrometria de emissão atômica}

A avaliação foi realizada para quantificar o cálcio perdido dos espécimes após desafio ácido. A análise foi feita nas soluções desmineralizantes (suco de laranja e suco gástrico) combinadas com a água destilada usada para lavar os espécimes, com volume final de $336 \mathrm{ml}$ para cada espécime.

Foi avaliado o conteúdo de cálcio $(\mathrm{Ca})$ perdido de cada espécime e também o valor de Ca presente nos sucos sem a imersão dos espécimes para servir como padrão de referência (branco). O branco refere-se ao conteúdo de cálcio presente nos sucos antes da imersão dos espécimes. O conteúdo de cálcio perdido dos espécimes foi calculado pela diferença entre o encontrado nos sucos após a imersão dos espécimes e o branco. 
Os espécimes imersos em suco de laranja perderam 7,07 mg/L de $\mathrm{Ca}$ em média e os espécimes imersos em suco gástrico perderam 12,74mg/L (Tabela 5.2).

Os dados foram submetidos à análise estatística com o Test $\mathrm{t}$ Student $(\mathrm{t}=$ 4,93), havendo diferença estatística $p=0,0003$.

Tabela 5.2 - Valores da perda de Ca dos espécimes após ciclagem nas soluções desmineralizantes

\begin{tabular}{l|l|l|l|l|l|l|l}
\hline \multicolumn{2}{l}{ Perda de cálcio (mg/L) - Suco gástrico } & \multicolumn{3}{l}{ Perda de cálcio (mg/L) - Suco de laranja } \\
\hline Espécimes & $\begin{array}{l}\text { Suco após imersão } \\
\text { dos espécimes }\end{array}$ & branco & diferença & Espécimes & $\begin{array}{l}\text { Suco após imersão } \\
\text { dos espécimes }\end{array}$ & branco & diferença \\
\hline 1 & 33,71 & 20,9 & 12,81 & 1 & 15,61 & 5,72 & 9,89 \\
\hline 2 & 32,08 & 20,9 & 11,18 & 2 & 12,23 & 5,72 & 6,51 \\
\hline 3 & 36,94 & 20,9 & 16,04 & 3 & 13,55 & 5,72 & 7,83 \\
\hline 4 & 34,92 & 20,9 & 14,02 & 4 & 13,57 & 5,72 & 7,85 \\
\hline 5 & 29,71 & 20,9 & 8,81 & 5 & 10,59 & 5,72 & 4,87 \\
\hline 6 & 37,37 & 20,9 & 16,47 & 6 & 13,47 & 5,72 & 7,75 \\
\hline 7 & 39,19 & 20,9 & 18,29 & 7 & 13,31 & 5,72 & 7,59 \\
\hline 8 & 31,28 & 20,9 & 10,38 & 8 & 12,79 & 5,72 & 7,07 \\
\hline 9 & 29,99 & 20,9 & 9,09 & 9 & 11,39 & 5,72 & 5,67 \\
\hline 10 & 31,21 & 20,9 & 10,31 & 10 & 11,43 & 5,72 & 5,71 \\
\hline Soma & & & 127,4 & Soma & & 70,74 \\
\hline Média & & & 12,74 & Média & & 7,07 \\
\hline Desvio-padrão & & 1,05 & Erro padrão & & 1,45 \\
\hline Erro padrão & & & & & \\
\hline
\end{tabular}




\subsubsection{Espectroscopia Raman}

A avaliação foi realizada no esmalte exposto na janela de $3 \times 3 \mathrm{~mm}$ em um ponto central antes dos ciclos de desmineralização-remineralização e após o desafio erosivo.

As médias das intensidades dos picos apresentados pelos espécimes antes e após a ciclagem em suco gástrico e suco de laranja estão representadas nas figuras 5.2 e 5.3, respectivamente.

As tabelas 5.3 e 5.4 apresentam a média da área sob os picos avaliados, antes e após a ciclagem em suco gástrico e suco de laranja respectivamente.

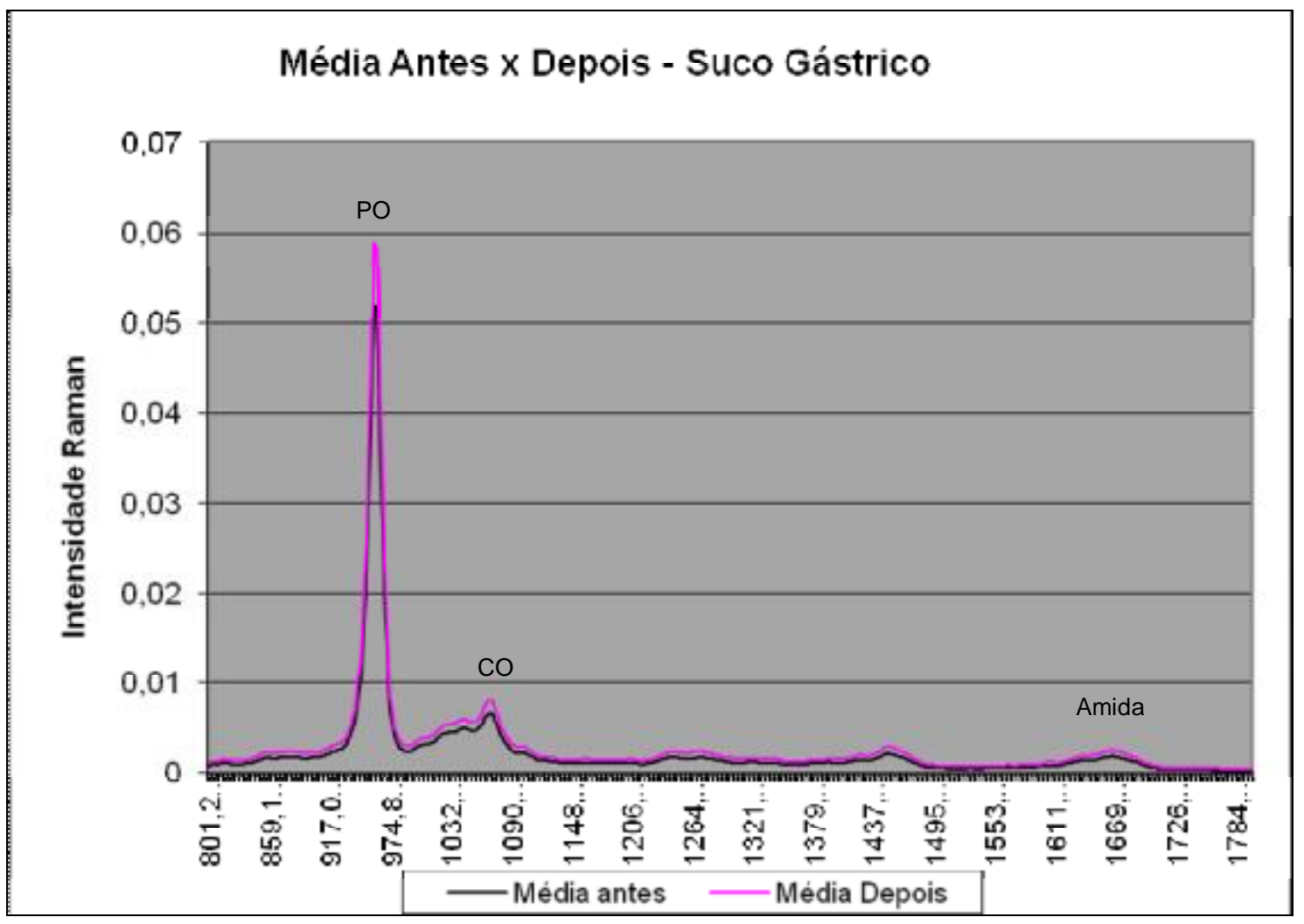

Figura 5.2 - Média da intensidade dos picos antes e após ciclagem em suco gástrico 


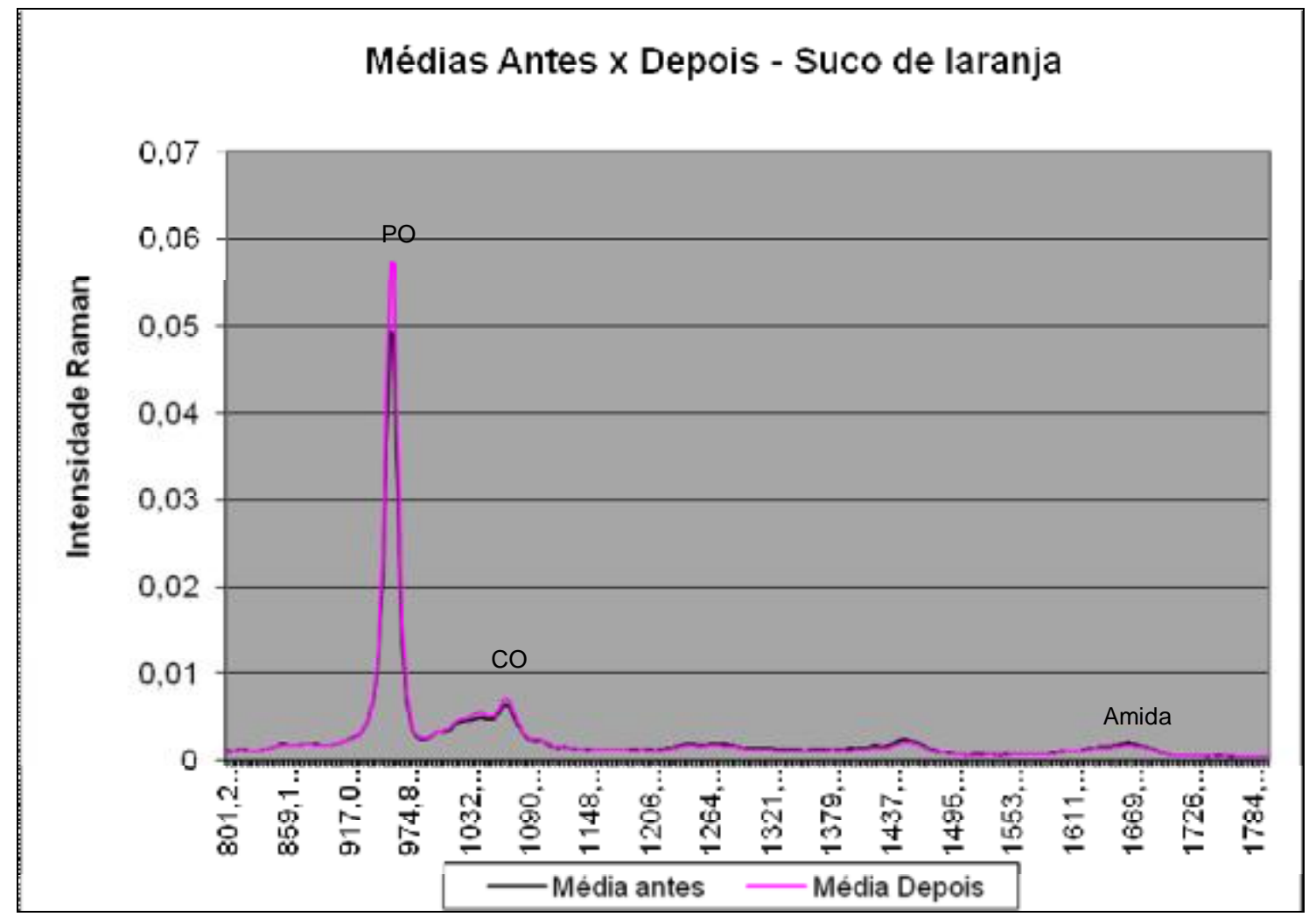

Figura 5.3 - Média da intensidade dos picos antes e após ciclagem em suco de laranja

Tabela 5.3 - Média da área sob os picos avaliados antes e após ciclagem em suco gástrico

\begin{tabular}{l|c|c}
\hline \multicolumn{1}{c|}{ Pico $\left(\mathbf{c m}^{-1}\right)$} & Antes da ciclagem & Após a ciclagem \\
\hline 960 (fosfato) & 0,93 & 1,08 \\
\hline 1045 (carbonato) & 0,08 & 0,11 \\
\hline 1072 (carbonato) & 0,15 & 0,18 \\
\hline 1668 (amida) & 0,03 & 0,06 \\
\hline
\end{tabular}

A avaliação das mudanças nas estruturas minerais e orgânicas foi executada comparando-se a razão entre as áreas sob os picos em 1045, 1072 cm$^{-1}$ (carbonato), e $1668 \mathrm{~cm}^{-1}$ (amida) com o pico de $960 \mathrm{~cm}^{-1}$ (fosfato) antes e após a ciclagem em suco gástrico e suco de laranja. 
Tabela 5.4 - Média da área sob os picos avaliados antes e após ciclagem em suco de laranja

\begin{tabular}{l|c|c}
\hline \multicolumn{1}{c|}{ Pico $\left(\mathbf{c m}^{-1}\right)$} & Antes da ciclagem & Após a ciclagem \\
\hline 960 (fosfato) & 0,85 & 1,03 \\
\hline 1045 (carbonato) & 0,10 & 0,09 \\
\hline 1072 (carbonato) & 0,15 & 0,14 \\
\hline 1668 (amida) & 0,04 & 0,03 \\
\hline
\end{tabular}

Não houve alteração estatisticamente significante entre as razões das áreas sob os picos estudados com o pico do fosfato antes e após a ciclagem em suco gástrico, avaliado pelo teste t de Student para duas amostras em par de médias (Tabela 5.5).

Tabela 5.5 - Média da razão da área sob os picos estudados com a média da área sob o pico do fosfato $\left(960 \mathrm{~cm}^{-1}, \mathrm{PO}\right)$ antes e após ciclagem em suco gástrico e análise estatística

\begin{tabular}{c|c|c|c}
\hline Razão & Antes da ciclagem & Após a ciclagem & Valor de $\mathbf{p}$ \\
\hline $1045 / \mathrm{PO}$ & 0,09 & 0,10 & 0,28 \\
\hline $1072 / \mathrm{PO}$ & 0,16 & 0,17 & 0,37 \\
\hline $1668 / \mathrm{PO}$ & 0,03 & 0,05 & 0,31 \\
\hline
\end{tabular}

Após a ciclagem em suco de laranja foi encontrada diminuição na razão das áreas sob os picos do carbonato com o do fosfato (Tabela 5.6), mas não havendo diferença estatística (teste t Student). 
Tabela 5.6 - Média da razão da área sob os picos estudados com a média da área sob o pico do fosfato $\left(960 \mathrm{~cm}^{-1}, \mathrm{PO}\right)$ antes e após ciclagem em suco de laranja e análise estatística

\begin{tabular}{c|c|c|c}
\hline Razão & Antes da ciclagem & Após a ciclagem & Valor de $\mathbf{p}$ \\
\hline $1045 / \mathrm{PO}$ & 0,12 & 0,09 & 0,06 \\
\hline $1072 / \mathrm{PO}$ & 0,18 & 0,14 & 0,16 \\
\hline $1668 / \mathrm{PO}$ & 0,05 & 0,03 & 0,57 \\
\hline
\end{tabular}

5.1.4 Microscopia eletrônica de varredura

As fotomicrografias apresentadas na figura 5.4 ilustram o aspecto morfológico da superfície de esmalte após o polimento, no início do experimento, e após ciclagem com suco gástrico ou suco de laranja.

O esmalte após ciclagem em suco gástrico mostra superfície com aparência de favo de mel característico de padrão de condicionamento ácido do tipo I, com o centro dos primas côncavos e a região periférica relativamente intacta (Figura 5.4 $\left.B_{2}\right)$. A superfície do esmalte após ciclagem em suco de laranja apresenta padrão de condicionamento tipo III, com rugosidade generalizada (Figura $5.4 \mathrm{C}_{2}$ ). 

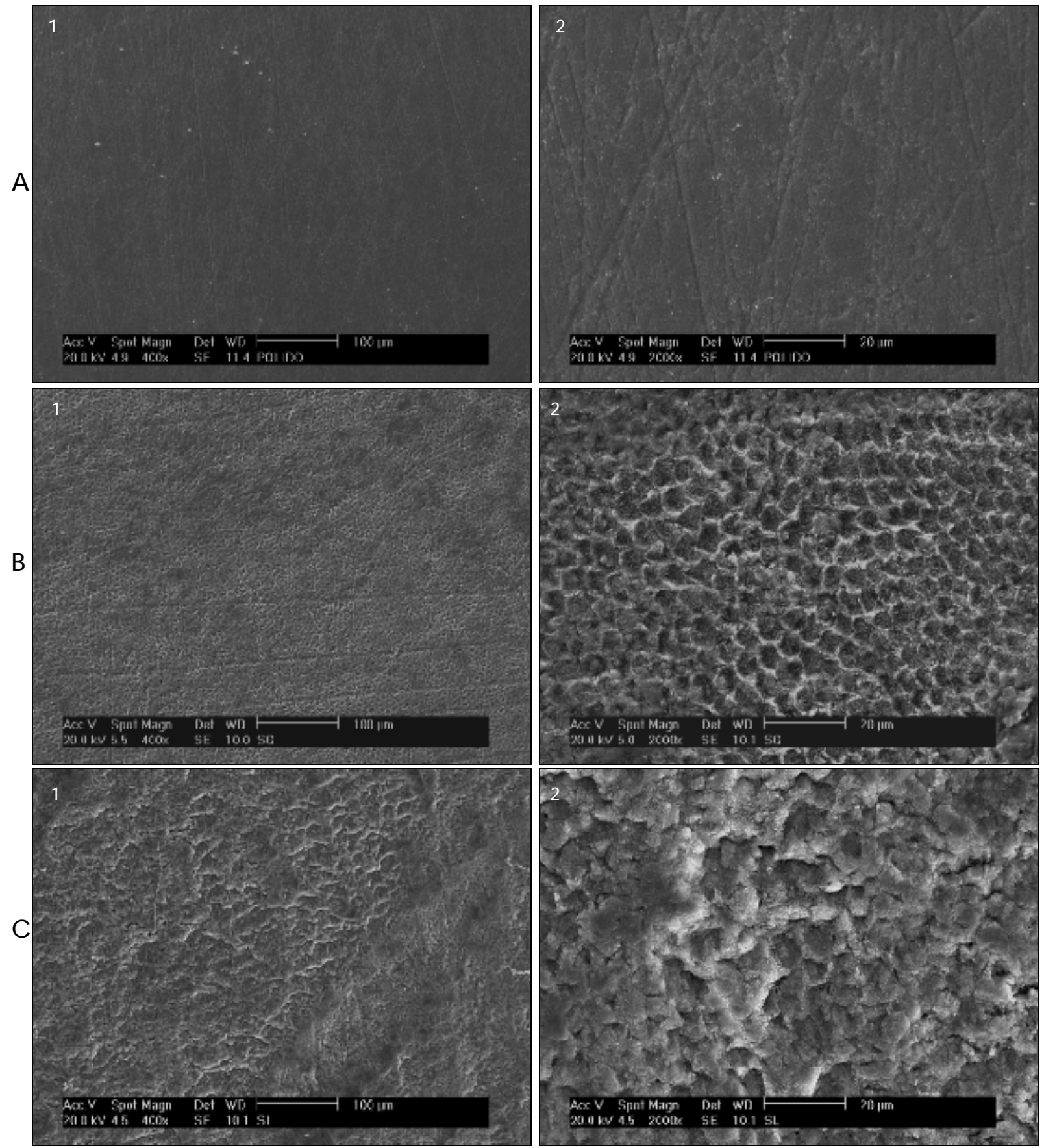

Figura 5.4 - Fotomicrografias da superfície dos espécimes (1 aumento 400x, 2 aumento 2000x). A Superfície após polimento para início da ciclagem. B Superfície após ciclagem em suco gástrico. C Superfície após ciclagem em suco de laranja 


\subsection{Resultados da Segunda Fase}

$\mathrm{Na}$ segunda fase do experimento foram avaliadas técnicas de controle da erosão dental também utilizando dois métodos de avaliação: a espectrometria de emissão atômica e a rugosidade superficial.

\subsubsection{Espectrometria de emissão atômica}

A análise do cálcio perdido pelos espécimes foi realizada conforme descrito nos resultados da primeira fase, subtraindo o valor total, encontrado nas soluções após erosão, do valor padrão (branco) do ácido clorídrico para obter o valor de cálcio perdido pelos espécimes.

O branco de cálcio encontrado no ácido clorídrico utilizado para erosão foi de 0,222 mg/L. A tabela 5.7 já mostra os valores de cálcio perdido pelos espécimes após a erosão em ácido clorídrico. O grupo onde foi aplicado o flúor + laser apresentou a menor perda de cálcio após o desafio ácido.

A análise estatística revelou uma distribuição amostral normal e homogênea por isso foi realizado o teste ANOVA, com um fator de variação $(p=0,0000008)$, havendo diferença estatística entre os grupos. Para a comparação entre os grupos foi executado o teste de Tukey $(p<0,0001)$ (Figura 5.5). 
Tabela 5.7 - Valores de cálcio perdido pelos espécimes, média, desvio-padrão e erro-padrão dos respectivos grupos de métodos de controle da erosão após desafio ácido

\begin{tabular}{c|c|c|c|c}
\hline Espécimes & FLÚOR & LASER & $\begin{array}{c}\text { FLÚOR + } \\
\text { LASER }\end{array}$ & $\begin{array}{c}\text { LASER + } \\
\text { FLÚOR }\end{array}$ \\
\hline 1 & 1,768 & 1,553 & 1,378 & 1,573 \\
\hline 2 & 1,791 & 1,721 & 1,377 & 1,564 \\
\hline 3 & 1,915 & 1,562 & 1,398 & 1,557 \\
\hline 4 & 1,763 & 1,635 & 1,423 & 1,439 \\
\hline 5 & 1,760 & 1,566 & 1,573 & 1,445 \\
\hline 6 & 1,582 & 1,594 & 1,354 & 1,398 \\
\hline 7 & 1,546 & 1,657 & 1,339 & 1,482 \\
\hline 8 & 1,649 & 1,580 & 1,401 & 1,541 \\
\hline 9 & 1,679 & 1,738 & 1,317 & 1,427 \\
\hline 10 & 1,616 & 1,769 & 1,290 & 1,416 \\
\hline Média & 1,707 & 1,638 & 1,385 & 1,484 \\
\hline Desvio-padrão & 0,113 & 0,080 & 0,078 & 0,068 \\
\hline Erro-padrão & 0,036 & 0,025 & 0,024 & 0,021 \\
\hline
\end{tabular}

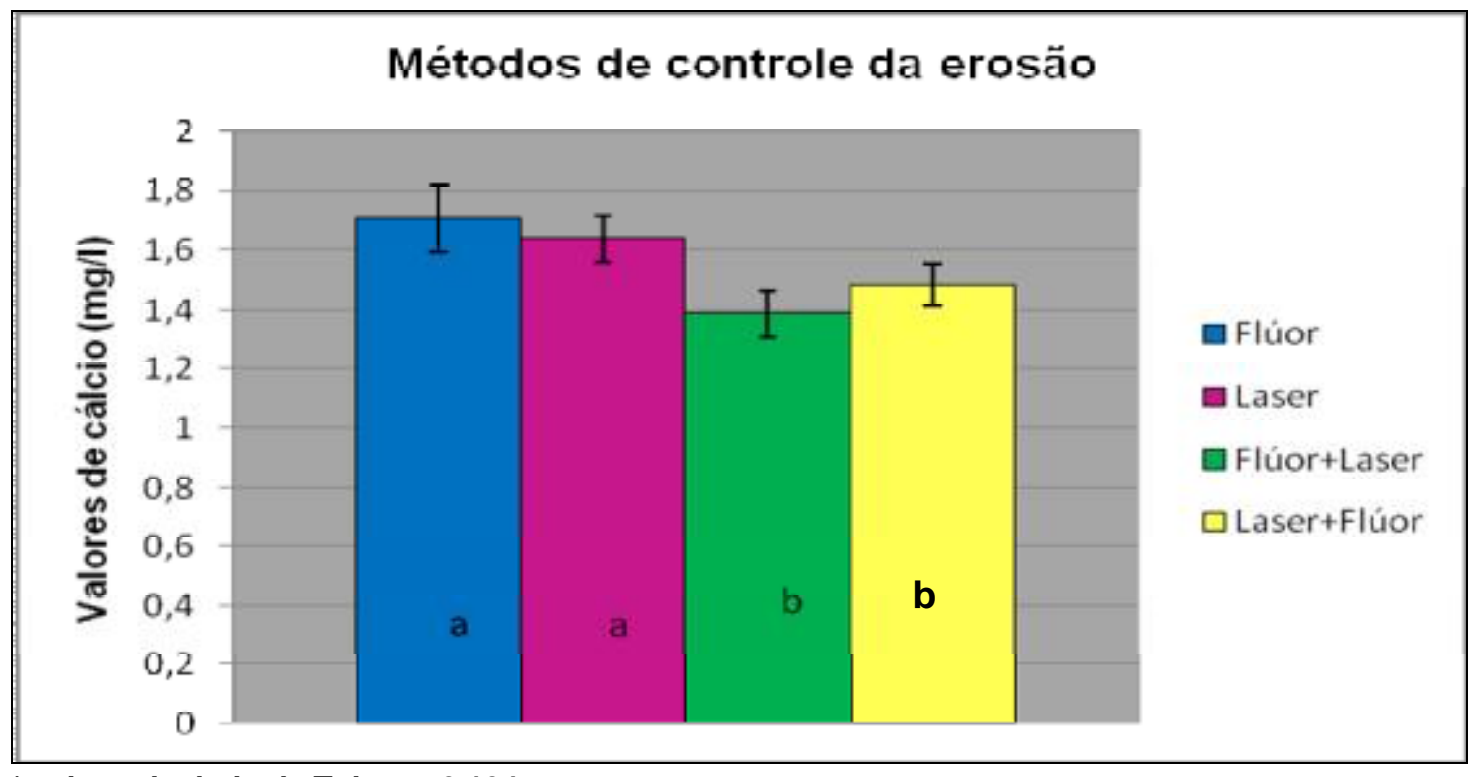

* valor calculado de Tukey $=0,104$

** letras iguais indicam ausência de diferença estatística

Figura 5.5 - Comparação entre as médias de cálcio perdido dos grupos de métodos de controle da erosão e a análise estatística 
5.2.2 Rugosidade superficial

Os valores da rugosidade superficial de cada espécime antes e após a aplicação dos métodos de controle da erosão e desafio erosivo, média, desviopadrão e erro-padrão estão representados na tabela 5.8.

Tabela 5.8 - Valores de Ra $(\mu \mathrm{m})$, média, desvio-padrão e erro-padrão dos espécimes antes e após aplicação dos respectivos métodos de controle de erosão e desafio erosivo

\begin{tabular}{c|c|c|c|c|c|c|c|c}
\hline & \multicolumn{2}{|c|}{ FLÚOR } & \multicolumn{2}{c|}{ LASER } & \multicolumn{2}{c}{ FLÚOR+LASER } & \multicolumn{2}{c}{ LASER+FLÚOR } \\
\hline & antes & após & antes & após & antes & após & antes & após \\
\hline 1 & 0,11 & 0,59 & 0,17 & 0,71 & 0,12 & 0,54 & 0,17 & 0,77 \\
\hline 2 & 0,18 & 0,74 & 0,14 & 0,82 & 0,13 & 0,76 & 0,15 & 0,71 \\
\hline 3 & 0,15 & 0,74 & 0,17 & 0,90 & 0,14 & 0,59 & 0,16 & 0,72 \\
\hline 4 & 0,14 & 0,72 & 0,16 & 0,95 & 0,12 & 0,56 & 0,11 & 0,66 \\
\hline 5 & 0,14 & 0,62 & 0,19 & 0,68 & 0,14 & 0,67 & 0,17 & 0,61 \\
\hline 6 & 0,12 & 0,60 & 0,12 & 0,85 & 0,18 & 0,50 & 0,16 & 0,84 \\
\hline 7 & 0,05 & 0,58 & 0,17 & 0,82 & 0,22 & 0,69 & 0,09 & 0,67 \\
\hline 8 & 0,20 & 0,80 & 0,17 & 0,92 & 0,14 & 0,52 & 0,16 & 0,70 \\
\hline 9 & 0,16 & 0,65 & 0,12 & 1,08 & 0,14 & 0,72 & 0,11 & 0,80 \\
\hline 10 & 0,16 & 0,83 & 0,08 & 0,96 & 0,18 & 0,59 & 0,14 & 0,75 \\
\hline Média & 0,14 & 0,69 & 0,15 & 0,87 & 0,15 & 0,61 & 0,14 & 0,72 \\
\hline Desvio-padrão & 0,041 & 0,091 & 0,033 & 0,119 & 0,032 & 0,090 & 0,029 & 0,069 \\
\hline Erro-padrão & 0,013 & 0,029 & 0,011 & 0,038 & 0,010 & 0,028 & 0,009 & 0,022 \\
\hline
\end{tabular}

A distribuição amostral testada foi normal por isso foi realizado a Análise de Variância (ANOVA) para dois fatores de variação, encontrando diferença estatística entre os grupos $(p=0,000061)$. Para a comparação entre os grupos foi realizado o teste de Tukey $(p<0,05)$. A rugosidade superficial inicial dos grupos foi semelhante, 
não havendo diferença estatística entre eles. Após os métodos de controle da erosão e desafio erosivo os grupos apresentaram diferenças estatisticamente significantes entre si $(p<0,05)$, sendo que o grupo Flúor + Laser apresentou a menor rugosidade, mas não havendo diferença estatística com o grupo do Flúor. O grupo Laser apresentou a maior rugosidade superficial (Figura 5.6).

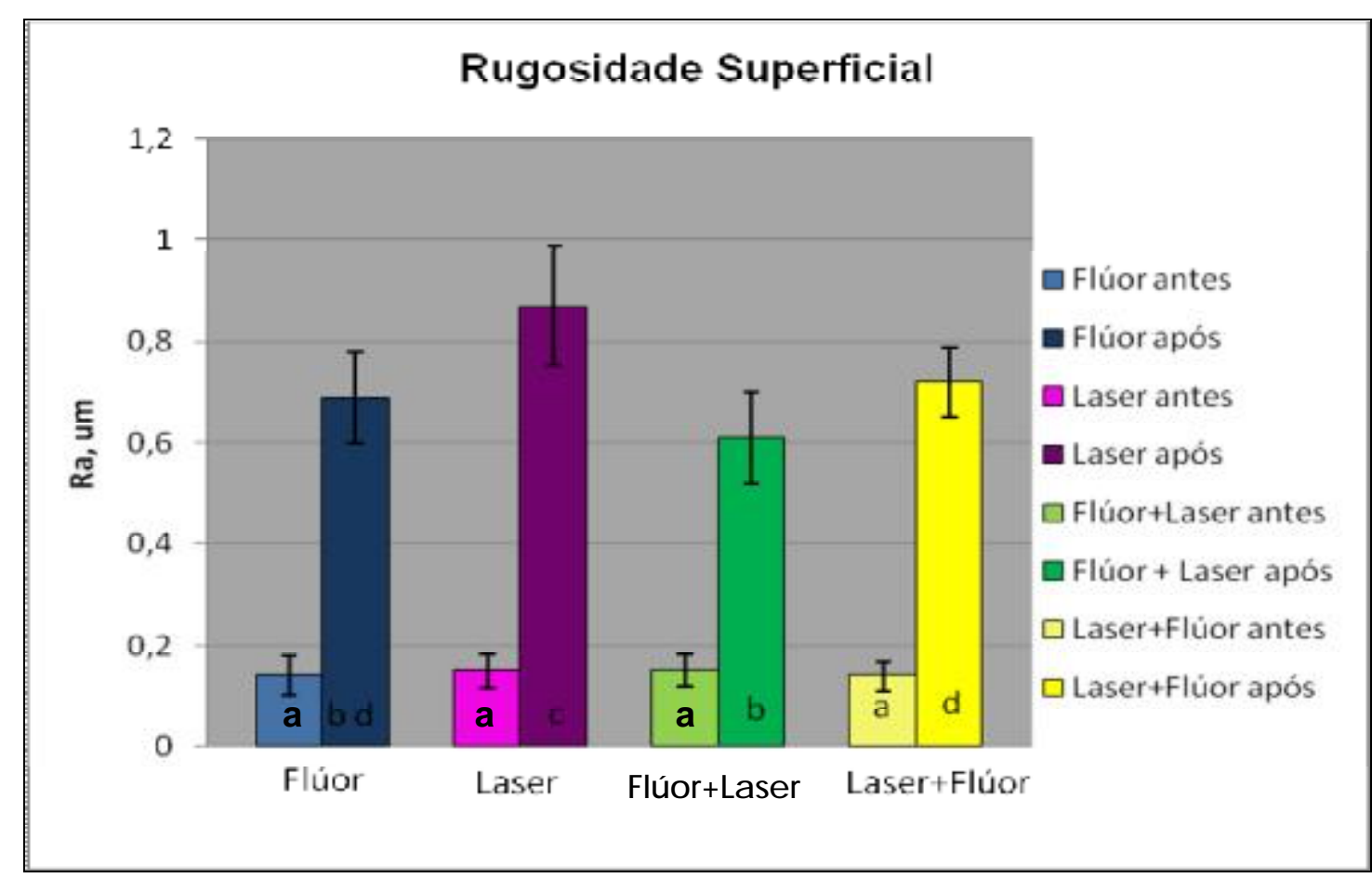

* valor calculado de Tukey $=0,09$

** letras iguais indicam ausência de diferença estatística

Figura 5.6 - Médias e desvios-padrão da rugosidade superficial antes e após os métodos de controle da erosão e desafio erosivo, análise estatística 
5.2.3 Microscopia eletrônica de varredura

As fotomicrografias apresentadas na figura 5.7 ilustram o aspecto morfológico da superfície de esmalte após o tratamento com os métodos avaliados de controle da erosão e do desafio erosivo.

A superfície onde foi aplicado flúor (Figura $5.7 \quad A_{2}$ ) apresenta padrão de condicionamento ácido do tipo I com característica de favo de mel.

As superfícies que foram irradiadas com laser de Nd:YAG, tanto aquela onde somente foi aplicado o laser quanto naquelas onde houve associação com a aplicação de flúor, apresentam superfícies com rugosidade generalizada, sem padrão único de condicionamento (Figura 5.7 B, C, D). 
A
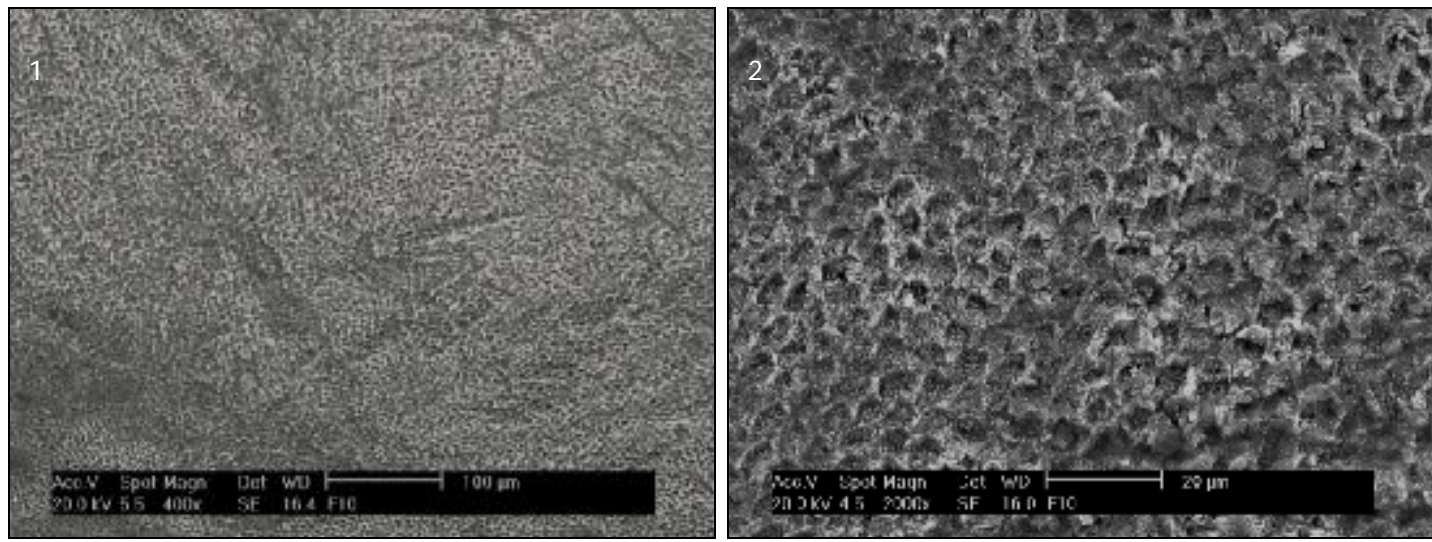

B
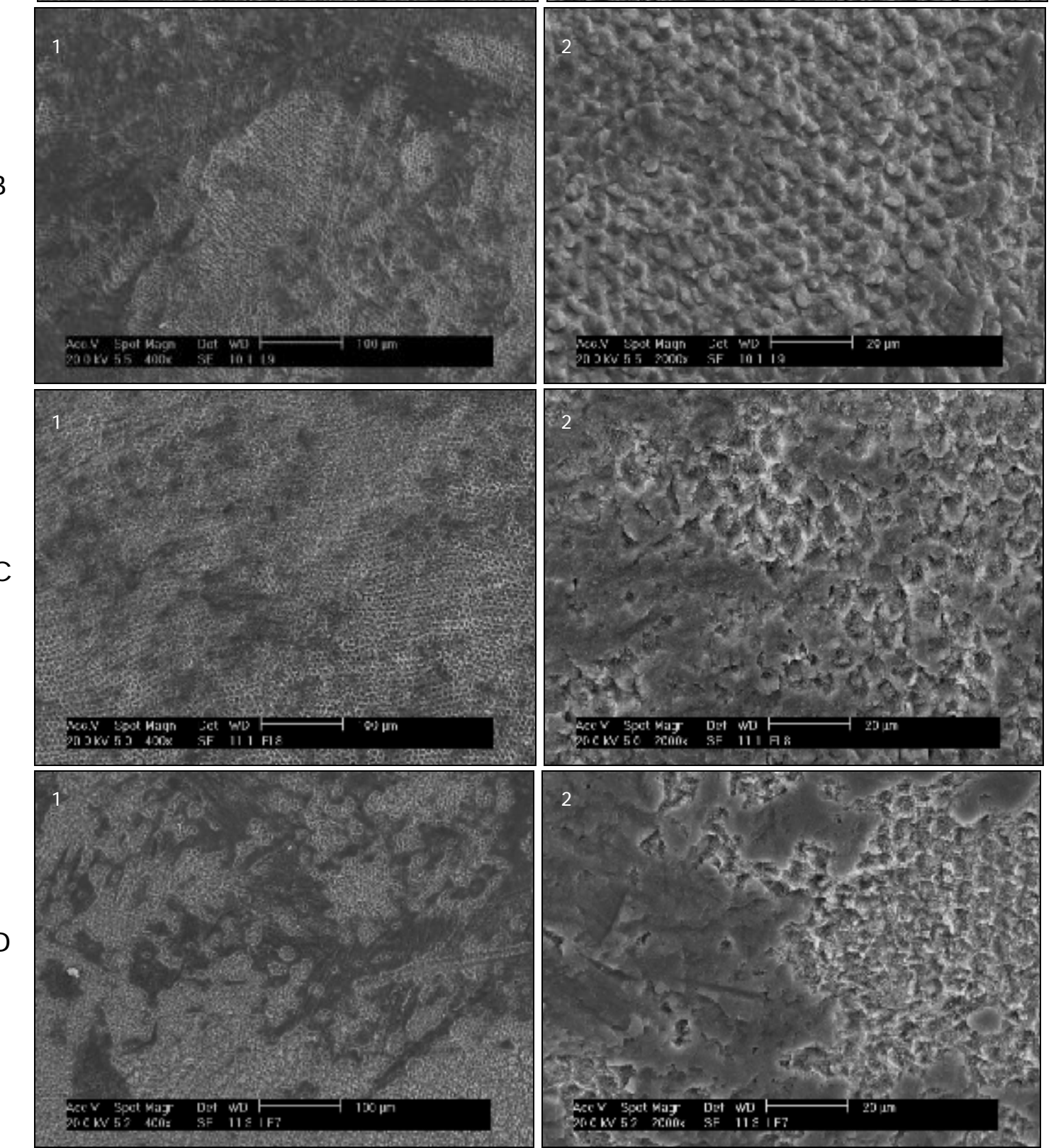

Figura 5.7 - Fotomicrografias da superfície dos espécimes (1 aumento 400x, 2 aumento 2000x). A Superfície após aplicação de flúor e desafio ácido. B Superfície após irradiação com laser Nd:YAG e desafio ácido. C Superfície após aplicação de flúor + irradiação com laser de Nd:YAG e desafio ácido. D Superfície após irradiação com laser de Nd:YAG + aplicação de flúor e desafio ácido 


\section{DISCUSSÃO}

A discussão está dividida em três partes para melhor expor o texto neste capítulo.

\subsection{Da Proposição}

Nos anos recentes, o desgaste dental tem recebido maior atenção na comunidade odontológica e tem sido atribuído principalmente à erosão dental.

A erosão dental é a perda de tecido duro, ácido induzida, que não envolve bactérias, e é, portanto, não associada com a placa dental. Os fatores etiológicos da erosão dental são frequentemente categorizados em dois grupos: fatores intrínsecos e extrínsecos. Agentes extrínsecos incluem substâncias ácidas, bebidas, alimentos, medicação e exposição a ambientes com agentes ácidos. Causas intrínsecas da erosão incluem vômitos recorrentes como parte de desordens alimentares (anorexia ou bulimia nervosa) ou à regurgitação do conteúdo gástrico (refluxo gastroesofágico) (BARBOUR; REE, 2004).

O refluxo gastro-esofágico é uma das desordens digestivas mais comuns. O refluxo é a passagem do conteúdo gástrico até o esôfago e cavidade bucal por uma falha no fechamento do baixo esfíncter esofágico (BARRON et al., 2003). A etiologia pode estar associada à hérnia de hiato, fumo, álcool, pobres hábitos alimentares, alergias a alimentos, medicamentos anticolinérgicos ou relaxantes musculares. $\mathrm{O}$ 
aumento no volume ou pressão gástrica (por exemplo, na obesidade e gravidez) também favorece o refluxo gástrico (CARRETERO; CALLEJA, 2006).

Um dos primeiros estudos relacionando o ácido gástrico e a erosão dental foi em 1937, com base em um caso clínico de um paciente com vômito crônico. Literatura mais recente sugere que os fatores intrínsecos como regurgitação no refluxo gastro-esofágico e vômito podem ocorrer em mais de $25 \%$ dos casos de erosão dental (JENSDOTTIR et al., 2004). Há, entretanto, informações conflitantes na literatura; Jarvinen, Meurman e Hyvarinen (1988) examinaram 109 pacientes com sintomas de distúrbios gastrointestinais e encontraram apenas $6,4 \%$ deles com erosão dental enquanto Meurman et al. (1994) encontraram 26,2\% dos 107 pacientes diagnosticados com refluxo gastro-esofágico apresentando erosão dental.

Porém, há evidências que severos desgastes dentais são causados pela regurgitação no refluxo gastro-esofágico. A acidez do conteúdo gástrico pode ter pH inferior a um, e uma vez regurgitado pode ser fortemente danoso ao dente causando erosão dental (MEURMAN et al., 1994). Bartlett, Evans e Smith (1996), em um estudo controlado de 40 pacientes apresentando desgaste patológico dos dentes, observou que $60 \%$ destes apresentavam níveis patológicos de refluxo, avaliado em monitoramento ambulatorial do pH. Schroeder et al. (1995), também observou a presença de erosão dental em um grupo de 30 pacientes com refluxo, sendo que doze destes tinham desgaste dental.

Além disso, a erosão do esmalte tem sido considerada a manifestação mais óbvia da bulimia. A prevalência de erosão no esmalte em pacientes com bulimia é de 33-38\% (SPIGSET, 1991). Robb, Smith e Geidrys-Leeper (1995) observaram que pacientes que sofrem de anorexia e bulimia nervosa apresentam mais erosão que pacientes-controle. 
Portanto, a erosão dental é uma manifestação comum em pacientes que sofrem desordens orgânicas ou psicossomáticas tais como anorexia, bulimia e alcoolismo (WIEGAND; ATTIN, 2007).

Por outro lado, bebidas ácidas têm sido reconhecidas como um poderoso fator extrínseco de erosão dental. Estudos têm verificado que a alta prevalência de erosão dental em crianças e adultos jovens relaciona-se com o consumo de refrigerantes e outros fatores da dieta (JENSDOTTIR et al., 2004).

A atividade erosiva do ácido cítrico, maleico, fosfórico e outros ácidos como ingredientes de bebidas e alimentos tem sido demonstrada em muitos estudos in vitro, in situ e in vivo (LUSSI; PORTMANN; BURSHOP, 1997; MEURMAN et al., 1987, 1990). Controle de casos, estudos transversais e inúmeros casos clínicos também mostram a dieta como sendo um importante fator etiológico para o desenvolvimento e progressão da erosão (LUSSI; JAEGGI; ZERO, 2004).

O suco de laranja é o suco de fruta mais popular no mundo e sua popularidade é resultado do conhecimento de seus benefícios à saúde pelo seu conteúdo de vitamina C. Mas o suco de laranja também contém alto nível de ácido cítrico (de baixo pH), o qual pode erodir o esmalte e dentina. Em adição a isto, o ácido cítrico é um agente quelante o que aumenta seu potencial erosivo (REES; LOYN; GILMOUR, 2006).

Clinicamente o efeito da erosão dental, seja de origem extrínseca ou intrínseca, é a perda de estrutura dental. A literatura comparando o efeito de ácidos de origem extrínseca e intrínseca é muito escassa. Bartlett, Evans e Smith (1996) e Scheutzel (1996), encontraram que o suco gástrico foi mais erosivo do que bebidas ácidas carbonatadas usualmente contendo como ingrediente o ácido fosfórico ou cítrico. 
O elevado consumo de bebidas ácidas, e um aparente aumento na prevalência de doenças gastro-esofágicas e distúrbios alimentares, os quais levam ao frequente contato entre dente e o conteúdo gástrico, são fatores de risco para destruição dental não cariosa (ten CATE; IMFELD, 1996). Por isso houve um interesse em estudar os efeitos erosivos do suco de laranja e suco gástrico sobre o esmalte dental e compará-los.

Além disso, mudanças no estilo de vida e hábitos alimentares contribuíram para um aumento dos desafios ácidos para a dentição, fazendo da erosão uma condição patológica de especial interesse nas pesquisas odontológicas contemporâneas.

Atualmente a prevenção ou controle da erosão dental tornou-se um importante objetivo para pesquisadores e clínicos. Muitos estudos utilizando diferentes formulações de flúor, por exemplo: fluoreto de sódio, flúor fosfato acidulado, fluoreto estanhoso, flúor amino ou tetrafluoreto de titânio mostraram um efeito protetor contra a erosão dental in vitro (GANSS et al., 2001; HUGHES; WEST; ADDY, 2004; VAN RIJKON et al., 2003; WILLUMSEN et al., 2004).

Para nós o termo "controle" é o mais adequado do que o termo prevenção. É difícil impedir completamente a ação dos ácidos de origem extrínseca ou intrínseca sobre o esmalte na cavidade bucal. Busca-se atualmente algum método que consiga minimizar em graus variáveis o efeito da fonte ácida sobre o esmalte. Assim, a medida primária no controle da erosão dental consiste em reduzir ou eliminar o contato do tecido dental com os agentes erosivos.

Sabendo da dificuldade em se eliminar por completo a exposição da estrutura dental a fontes ácidas optou-se por estudar métodos de controle da erosão dental na 
tentativa de encontrar um tratamento que evite a progressão da lesão e as consequentes extensas perdas de estrutura dental.

\subsection{Dos Materiais e Métodos utilizados}

6.2.1 Na primeira fase

Nesta fase comparou-se o potencial erosivo de uma fonte ácida intrínseca com uma fonte ácida extrínseca, utilizou-se o suco gástrico coletado de pacientes submetidos a exames de endoscopia para simular a fonte ácida de origem intrínseca.

O frequente contato do suco gástrico com a dentição leva à erosão dental, esta condição ocorre principalmente em pacientes que sofrem de refluxo gastroesofágico, anorexia nervosa e bulimia (HANNIG et al., 2005).

O refluxo gástrico apresenta $\mathrm{pH}$ menor que 2,0. O pH do "pool" (coletado de 45 pacientes) de suco gástrico neste estudo foi de 1,61 conseguindo simular a fonte ácida nos casos de erosão por origem intrínseca.

Já a fonte extrínseca foi simulada com suco de laranja industrializado por representar uma amostra mais homogênea do que o suco natural, onde há uma variedade de tipos de laranjas, época de colheita, que poderiam causar uma variabilidade muito grande na amostra. O suco de laranja é uma bebida largamente consumida e representativa do ácido cítrico. O ácido cítrico é considerado 
particularmente prejudicial aos dentes porque quelam o cálcio da hidroxiapatita, mesmo depois da elevação do pH, ao formar citratos solúveis (BASSIOUNY; KURODA; YANG, 2007; YIP; SMALES; KAIDONIS, 2003). Além disso, o suco de laranja é capaz de manter o $\mathrm{pH}$ baixo por períodos longos comparado com os refrigerantes, resultando em um potencial erosivo mais constante (JENSDOTTIR et al., 2006) por isso, foi escolhido como fonte ácida extrínseca.

$\mathrm{Na}$ quantificação da perda mineral dos espécimes foram utilizadas a Espectrometria de emissão atômica e a Espectroscopia FT-Raman.

A Espectrometria de emissão atômica é um método químico de análise de minerais dissolvidos no meio erosivo, é de fácil execução e bem estabelecido na literatura (ATTIN, 2006). Os métodos químicos para a avaliação da erosão têm a vantagem de permitir a detecção de perdas minerais muito pequenas.

O esmalte dental consiste de 34-39\% de cálcio e 16-18\% de fósforo. Portanto, a determinação da dissolução do esmalte dental pela avaliação da quantidade de cálcio ou fosfato dissolvido dos cristais de apatita dos tecidos duros dentais pode ser considerada como uma técnica importante para avaliar a erosão dental (ATTIN, 2006).

Os primeiros estudos por espectroscopia Raman de tecidos mineralizados dentais foi feito por Tsuda e Arens, em 1993. A espectroscopia Raman é uma técnica versátil e não destrutiva que permite a caracterização simultânea das fases inorgânica e orgânica do dente (LIU; HSU, 2006). A composição química dos substratos é analisada: a intensidade dos picos obtidos dos componentes inorgânicos (fosfato e carbonato), assim como do pico do componente orgânico, representado pela amida (colágeno), revela esta informação. Análises da mudança dos picos no espectro permitem que o conteúdo químico dos substratos seja 
diferenciado. Esta técnica também tem sido utilizada na Odontologia para estudar minerais sintéticos, formação de fluoreto de cálcio no esmalte, interface resinadentina em dentes restaurados (GILCHRIST et al., 2007; PARK et al., 2004; WENTRUP-BYRNE et al., 1997).

Diferente da maioria dos métodos analíticos, a espectroscopia Raman é uma técnica não destrutiva, onde as amostras não requerem preparação física antes da análise, e, portanto, ela mostra potencial para ser uma ferramenta útil no estudo de processos erosivos (GILCHRIST et al., 2007).

\subsubsection{Na segunda fase}

$\mathrm{Na}$ segunda fase deste trabalho foram estudados métodos de controle da erosão em esmalte dental. A fonte ácida empregada para simular a erosão foi o ácido clorídrico a 0,01 M e pH 2,2. Em estudo piloto, ao se avaliar a capacidade desmineralizante do ácido clorídrico, a 0,01 M e pH 2,2, verificou-se que esta apresentava-se semelhante ao do suco gástrico in natura, sendo amplamente empregado na literatura (HOVE et al., 2006; WILLUMSEN et al., 2004) na simulação do ácido gástrico. Portanto, para avaliação dos métodos de controle da erosão utilizou-se o ácido clorídrico nesta concentração, uma vez que, a coleta do suco gástrico em quantidade suficiente para a realização dos testes levaria muito tempo comprometendo sua conservação e possíveis resultados. Hove et al. (2008) também utilizaram o ácido clorídrico a 0,01M (pH 2,2) para simular uma condição de refluxo gastro-esofágico e avaliar diferentes fluoretos na prevenção da erosão dental. 
A incidência de erosão dental causada por fontes extrínseca ou intrínseca tem crescido muito atualmente e pouco se sabe sobre sua prevenção ou controle. $\mathrm{Na}$ intenção de colaborar com o aumento do conhecimento nesta área testamos quatro métodos de controle da erosão: flúor, laser Nd:YAG, e as associações entre estes.

O flúor é a principal forma de prevenção de cáries e foi, portanto, natural que o flúor fosse considerado como possível veículo para prevenção da erosão dental (HOLBROOK; ARMADOTTIR; KAY, 2003). O possível papel do flúor na erosão pode ser o de "endurecer" a superfície do dente e aumentar a resistência à dissolução ácida mais do que encorajar a remineralização como ocorre no processo de cárie (BARTLETT, 2005b). Testamos o gel de flúor acidulado (APF) por se tratar de um método simples, de fácil aplicação e acessível à maioria dos clínicos. Apesar da efetividade do flúor no controle da erosão ser questionado por alguns autores (LARSEN; NYVAD, 1999; LARSEN; RICHARDS, 2002), alguns trabalhos in vitro (AMAECHI; HIGHAM, 2005; ATTIN; DEIFUSS; HELLWIG, 1999; ATTIN; ZIRKEL; HELLWIG, 1998, GANSS et al., 2001; GRAUBART; GEDALIA; PISANTI, 1972; van RIJKOM et al., 2003) têm reportado uma significante redução da erosão depois da aplicação tópica de agentes fluoretados.

O laser de Nd:YAG foi utilizado neste trabalho por já ter sido avaliado como método de prevenção da desmineralização do esmalte na cárie dental com resultados promissores (BAHAR; TAGOMORI, 1994; BOARI; ZEZELL, 2001; CASTELLAN et al., 2007; TSAl et al., 2002; YAMAMOTO; SATO, 1980), mas poucos estudos o testaram para controle da erosão dental (MAGALHÃES et al., 2008b; SOBRAL et al., 2009). Os parâmetros selecionados foram previamente estudados, in vitro, por Sobral et al. (2009) mostrando-se eficientes no controle da erosão dental. 
O laser de Nd:YAG a 1,064 $\mu \mathrm{m}$ tem baixa absorção em hidroxiapatita, devido a isto utilizamos uma mistura de carvão e água para aumentar a eficiência de absorção do feixe de laser quando aplicado sobre o esmalte dental.

Outros fatores que contribuíram para a escolha do laser de Nd:YAG foram sua condução por fibra óptica possibilitando a aplicação em qualquer região da cavidade bucal, a necessidade do uso de um agente para aumentar a absorção em esmalte funcionando como um guia uma vez que nas áreas já irradiadas o corante desaparece e como não há absorção sem o corante diminui-se danos desnecessários ao tecido.

As associações entre o flúor e laser foram realizadas na tentativa de maximizar os efeitos dos dois agentes, mas como não há uma ordem préestabelecida na literatura da aplicação dos agentes, avaliamos a associação flúor + laser e laser + flúor. Tepper et al. (2004) optaram por aplicar o laser após a aplicação do flúor, já Boari e Zezell (2001) irradiaram o esmalte antes da aplicação do flúor. Vlacic, Meyers e Walsh (2007) investigaram a ação do flúor ativado pelo laser, agindo simultaneamente na proteção do esmalte dental contra um desafio erosivo.

Para avaliação dos métodos de controle da erosão testados utilizamos além da Espectrometria de emissão atômica a avaliação da rugosidade superficial. A rugosidade superficial foi avaliada para quantificar a alteração da topografia superficial ocorrida após aplicação dos métodos de controle e da erosão. 


\subsection{Dos Resultados}

\subsubsection{Da primeira fase}

Após ciclagem em suco gástrico os espécimes de esmalte dental humano perderam mais cálcio do que após ciclagem em suco de laranja. O suco gástrico revelou potencial erosivo maior, determinado principalmente pelo ácido clorídrico.

Bartlett, Evans e Smith (1996) verificaram que o suco gástrico $(\mathrm{HCl})$ foi mais erosivo do que bebidas ácidas carbonatadas usualmente produzidas com ácido fosfórico ou cítrico. West, Hughes e Addy (2001) também verificaram que o ácido clorídrico puro foi mais erosivo do que o ácido fosfórico. Bartlett e Coward (2001) compararam o efeito erosivo do suco gástrico com a Coca-Cola e concluíram que o suco gástrico apresentou maior potencial para erosão que o refrigerante. O suco gástrico tem se mostrado com potencial erosivo significativamente mais alto do que os refrigerantes (HANNIG et al., 2005).

Apesar do suco de laranja apresentar potencial erosivo maior que os refrigerantes (JENSDOTTIR et al., 2006), ele mostrou-se menos erosivo que o suco gástrico. Vários estudos in vitro e in situ têm avaliado o potencial erosivo de diferentes alimentos e bebidas. Eles mostram que o potencial erosivo de uma bebida ácida não é exclusivamente dependente de seu pH, mas é também fortemente influenciado pela titulação e pelas propriedades de cálcio-quelação da bebida (LUSSI; JAEGGI; ZERO, 2004; ten CATE; IMFELD, 1996; WIEGAND; ATTIN, 2007). 
O suco de laranja aqui testado apesar de apresentar valores maiores na titulação em comparação com o suco gástrico, apresentou menor poder erosivo, isto pode ser justificado, uma vez que o suco gástrico sendo muito ácido inicialmente, tem seu poder erosivo imediato superior a capacidade do suco de laranja de se manter ácido e promover a dissolução do esmalte.

A metodologia de espectroscopia FT-Raman empregada neste estudo não detectou diferença significativa no conteúdo mineral dos espécimes antes e após as ciclagens erosivas tanto em suco gástrico quanto em suco de laranja. Utilizando a espectroscopia Raman, Tramini et al. (2000) não verificaram alteração no espectro do esmalte após imersão por 7 dias em ácido lático (5 M, pH 4,5). Gilchrist et al. (2007) também não encontraram diferença estatisticamente significante entre a concentração do grupo fosfato em esmalte erodido e íntegro de dentes decíduos.

A análise da concentração de fosfato no esmalte é um bom indicador do grau de mineralização, portanto, seria de se esperar que o fosfato liberado nos processos tanto erosivo quanto no de cárie, resultasse em diminuição na intensidade da banda relacionada a este grupo mineral (GILCHRIST et al., 2007). Entretanto, o aumento na intensidade dos espectros verificado nos resultados deste estudo pode ser explicado pela alteração da superfície dos espécimes após a ciclagem ácida, alterando o ângulo de orientação dos cristais no esmalte, e consequentemente podendo alterar a intensidade dos espectros (PARK et al., 2004).

Erosão é um fenômeno superficial diferente da cárie onde o efeito ocorre na subsuperfície do esmalte ou dentina. Ácidos causam a desmineralização superficial dos tecidos duros dos dentes, primariamente pela dissolução dos cristais de apatita (MOAZZEZ; SMITH; BARTLETT, 2000). 
As fotomicrografias em MEV mostram a superfície do esmalte após ciclagem com suco gástrico com característica de favo de mel, mostrando condicionamento ácido denominado de Tipo I (SILVERSTONE, 1978), onde há rugosidade generalizada da superfície do esmalte, mas com padrão distinto, mostrando concavidade no centro dos prismas com a região periférica relativamente intacta. A superfície após ciclagem em suco de laranja apresentou padrão menos definido.

Na superfície do esmalte, o íon hidrogênio componente dos ácidos começa a dissolver os cristais do esmalte. Primeiro, a bainha e então o núcleo do prisma são dissolvidos, deixando a aparência bem conhecida de favo de mel. Outra parte do ácido ionizado difundirá eventualmente para as áreas interprismáticas do esmalte e dissolverá mais mineral na parte inferior da superfície (LUSSI et al., 2006).

\subsubsection{Da segunda fase}

Na avaliação dos métodos de controle da erosão dental, a associação entre flúor e laser resultou em menores perdas de cálcio pelo esmalte que a aplicação somente de uma das técnicas isoladas. Não houve diferença estatisticamente significante entre aplicação prévia ou posterior do flúor à irradiação laser.

Tem sido consistentemente demonstrado que lasers sob certas condições podem aumentar significativamente a resistência ácida do esmalte, por alterar a cristalinidade, solubilidade ácida e permeabilidade do esmalte (HSU et al., 2000; LIU; HSU, 2006; NELSON et al., 1987). 
Estudo realizado por Yamamoto e Ooya (1974), estudando prevenção de cárie dental, demonstrou que a superfície do esmalte irradiada pelo laser de Nd:YAG foi menos susceptível a desmineralização, possivelmente pela fusão da superfície. Entretanto, o derretimento e fusão da superfície podem não ser necessários para aumentar a resistência ácida (HSU et al., 2000; KANTOROWITZ; FEATHERSTONE; DENIEL, 1998; MCCORMACK et al., 1995), o que possibilitaria o uso de densidades de energia mais baixas e consequentemente temperaturas que não afetem a integridade pulpar. O aumento na resistência ácida poderia resultar das alterações químicas tais como a redução no conteúdo de carbonato da superfície do esmalte (NELSON et al., 1986) ou pela decomposição parcial da matriz orgânica (HSU et al., 2000).

A irradiação com o laser de Nd:YAG pode ter causado a diminuição do conteúdo de carbonato. Yamada et al. (2004) observaram por espectroscopia Raman que o pico correspondente ao carbonato (entre $1000-1130 \mathrm{~cm}^{-1}$ ) foi perdido após irradiação da superfície do esmalte com laser de Nd:YAG.

Foi observado que a hidroxiapatita carbonatada é termicamente e quimicamente menos estável assim como mais solúvel que a hidroxiapatita (WENTRUP-BYRNE et al., 1997). Embora sendo um precursor da hidroxiapatita, o carbonato pode causar alguns defeitos no cristal e gerar uma apatita instável e mais ácido-solúvel (ROBINSON et al., 2000). Estes estudos reforçam a idéia que a diminuição no conteúdo de carbonato pode ser um dos motivos que contribuem para o aumento na resistência ácida do esmalte irradiado.

Embora represente menos de $1 \%$ do esmalte, a matriz orgânica pode ter um significante papel em inibir a difusão e a dissolução do esmalte, prevenindo, portanto, a sua desmineralização (NELSON; WILLIAMSON, 1982; TRAMINI et al., 
2000). Assim, a forma original da matriz orgânica pode ser denaturada pelo tratamento com laser e bloquear o caminho de difusão do ácido no esmalte (LIU; HSU, 2006).

Em avaliação em FT-Raman, Liu e Hsu (2006) observaram redução de 30\% na intensidade da banda correspondente à fase orgânica do esmalte e diminuição no carbonato tipo B, após tratamento com laser. Os resultados deste estudo sugerem que os tratamentos com lasers podem causar decomposição térmica da hidroxiapatita carbonatada e alterações orgânicas. Também Yamada et al. (2004) verificaram perda das bandas atribuídas a matriz orgânica no esmalte após irradiação com laser de $\mathrm{Nd}: Y A G$ e $\mathrm{CO}_{2}$.

A associação entre flúor e laser ocasionou um sinergismo entre as ações isoladas dos dois tratamentos. Provavelmente as alterações químicas e físicas causadas pela irradiação laser favoreçam a absorção do flúor, tanto o flúor já presente na superfície do esmalte quando a aplicação foi realizada antes da irradiação, quanto àquele que entra em contato com a superfície após irradiação.

Vários estudos suportam o aumento da absorção do flúor no esmalte irradiado (BAHAR; TAGOMORI, 1994; GOODMAN; KAUFMAN, 1977; HOSSAIN et al., 2002; TAGOMORI; MORIOKA, 1989).

Segundo Goodman e Kaufman (1977) irradiar o esmalte na presença de NaF causa um "melting" ou dissolução da estrutura cristalina do esmalte e subsequente recristalização e incorporação do flúor resultando em formação de fluorapatita a qual é menos solúvel do que a apatita original do esmalte.

Yamamoto e Sato (1980) encontraram uma redução na desmineralização de subsuperfície e absorção de grandes quantidades de flúor no esmalte após irradiação com laser de $\mathrm{Nd}$ :YAG depois do tratamento com $\mathrm{Ag}\left(\mathrm{NH}_{3}\right)_{2} \mathrm{~F}$. Já no estudo 
realizado por Tagomori e Morioka (1989) não foi encontrado grande aumento na resistência ácida quando o esmalte foi irradiado com laser de Nd:YAG depois do tratamento com NaF e APF, entretanto o esmalte tratado com APF após a irradiação laser tornou-se marcantemente ácido-resistente.

Também Bahar e Tagomori (1994) verificaram que a irradiação de fóssulas e fissuras de esmalte com laser de Nd:YAG tornou esta região 30\% mais ácidoresistente do que o controle não irradiado e além disso, a absorção de flúor nestas fóssulas e fissuras aumentou.

Tepper et al. (2004) encontraram efeitos benéficos na combinação da irradiação com laser de $\mathrm{CO}_{2}$ através da aplicação tópica de flúor amino, resultando em alta absorção de flúor e aumento na resistência ácida do esmalte. Vlacic, Meyers e Walsh (2007) avaliaram a irradiação de vários lasers associado ao fluoreto de sódio neutro, inclusive o laser de Nd:YAG, na prevenção da erosão. Os resultados mostraram que a irradiação juntamente com o flúor conferiu proteção à estrutura de esmalte contra o forte desafio erosivo empregado com ácido clorídrico. A associação do laser de Nd:YAG com flúor também apresentou melhores resultados no controle da erosão em estudo realizado por Sobral et al. (2009) do que a aplicação dos tratamentos isoladamente.

Enquanto o tratamento com laser em combinação com o flúor parece ter várias vantagens sobre a aplicação isolada destes tratamentos, alguns efeitos indesejáveis são observados na superfície do esmalte após tratamento com laser tais como rachaduras (FERREIRA et al., 1989; MCCORMACK et al., 1995). Não foi detectado por microscopia eletrônica de varredura, em nosso estudo, rachaduras nas superfícies irradiadas com laser. As imagens de MEV apresentam superfícies com aspecto de favo de mel que representa o condicionamento ácido do esmalte e 
áreas de rugosidades irregulares principalmente nas superfícies onde foi aplicado somente o laser e na associação laser + flúor.

É importante salientar que as superfícies avaliadas representam a ação dos métodos de controle da erosão testados e também da ação do ácido sobre a superfície do esmalte e não somente a irradiação laser ou uso do flúor acidulado. As superfícies onde foi empregada a associação do flúor + laser apresentaram a menor alteração de rugosidade provavelmente por tornar-se mais resistente à ação do ácido, enquanto o tratamento com laser isoladamente como método de controle da erosão apresentou maior alteração na rugosidade superficial comparado com os outros métodos.

Yamada et al. (2004) verificaram que superfícies dentárias irradiadas com lasers de $\mathrm{Nd}: Y A G, \mathrm{CO}_{2}$ e Er:YAG exibiram superfícies mais rugosas comparadas com superfícies não irradiadas. Após desafio erosivo em ácido lático, Tsai et al. (2002), observaram que os espécimes irradiados com laser de Nd:YAG apresentavam não somente padrão de condicionamento do tipo I e II mas também fissuras e áreas com erosão irregulares, comparada com o grupo controle que apresentava padrão tipo II de condicionamento.

Diferentemente do resultado encontrado neste estudo onde a associação laser + flúor apresentou superfície condicionada e com alteração de rugosidade semelhante ao grupo do flúor, Tagomori e Morioka (1989) verificaram que o esmalte tratado com flúor fosfato acidulado depois da irradiação com laser de Nd:YAG não mostrou alteração, exibindo aparência similar ao esmalte não condicionado, mesmo após 15 segundos de condicionamento em $\mathrm{HClO}_{4}$. Provavelmente a discrepância entre os períodos de condicionamento justifique a diferença de morfologia encontrada nos estudos. 
O aumento na rugosidade observado após os métodos de controle da erosão e desafio ácido poderia contribuir para o aumento na deposição de placa bacteriana sobre a superfície do esmalte tratado, entretanto, pacientes que apresentam erosão dental normalmente possuem um bom controle da placa bacteriana e a própria ação dos ácidos intrínsecos ou extrínsecos promovem a remoção desta placa. Portanto, esta alteração na rugosidade superficial do esmalte após os métodos de controle da erosão e desafio erosivo parece não representar um risco para o aumento na incidência de cárie dental ou doenças periodontais.

A erosão dental tornou-se foco de interesse tanto na odontologia clínica como nas pesquisas. Nas últimas duas décadas tem se visto numerosas investigações sobre a prevalência, etiologia e fatores modificadores da erosão dental. Agora é tempo de desenvolver programas preventivos para controlar os danos desta doença tão lesiva à estrutura dental. Por isso novos estudos in vitro e in situ avaliando agentes anti-erosivos e métodos de controle devem ser desenvolvidos para orientar a gerência da erosão dental na prática clínica. 


\section{CONCLUSÕES}

Sob as condições deste estudo in vitro foi possível concluir que:

7.1 O suco gástrico como fonte intrínseca de erosão dental apresentou potencial erosivo maior ao esmalte dental humano que o suco de laranja (fonte extrínseca).

7.2 A associação entre flúor (APF) e laser (Nd:YAG) mostrou-se mais eficaz como método de controle da erosão dental em esmalte após desafio erosivo com ácido clorídrico em comparação com os mesmos tratamentos isoladamente. 


\section{REFERÊNCIAS ${ }^{1}$}

Ali DA, Brown RS, Rodriguez LO, Moody EL, Nasr MF. Dental erosion caused by silent gastroesophageal reflux disease. J Am Dent Assoc 2002;133(6):734-7.

Amaechi BT, Higham SM. Dental erosion: possible approaches to prevention and control. J Dent 2005;33:243-52.

Attin T. Methods for assessment of dental erosion. Monogr Oral Sci 2006;20:152-72.

Attin T, Deifuss H, Hellwig E. Influence of acidified fluoride gel on abrasion resistance of eroded enamel. Caries Res 1999;33:135-9.

Attin T, Zirkel C, Hellwig E. Brushing abrasion of eroded dentin after apllication of sodium fluoride solutions. Caries Res 1998;32(5):344-50

Auad S, Moynihan P. Diet and dental erosion. Quintessence Int 2007;38(2):130-3.

Bahar A, Tagomori S. The effect of normal pulsed Nd:YAG laser irradiation on pits and fissures in human teeth. Caries Res 1994;28:460-7.

Barbour ME, Rees JS. The laboratory assessment of enamel erosion; a review. J Dent 2004;32:591-602.

Barron RP, Carmichael RP, Marcon MA, Sàndor GKB. Dental erosion in gastroesophageal reflux disease. J Can Dent Assoc 2003;69(2):84-9.

Bartlett DW. The implication of laboratory research on tooth wear and erosion. Oral Dis 2005a;11:3-6.

Bartlett DW. The role of erosion in tooth wear: aetiology, prevention and management. Int Dent J 2005b;55(4):277-84.

\footnotetext{
${ }^{1}$ De acordo com Estilo Vancouver. Abreviatura de periódicos segundo base de dados MEDLINE.
} 
Bartlett DW. A new look at erosive tooth wear in elderly people. J Am Dent Assoc 2007; 138(Suppl):215-55.

Bartlett DW, Coward PY. Comparison of the erosive potential of gastric juice and a carbonated drink in vitro. J Oral Rehabil 2001;28(11):1045-7.

Bartlett DW, Evans DF, Smith BG. The relationship between gastro-oesophageal reflux disease and dental erosion. J Oral Rehabil 1996;23:289-97.

Bartlett DW, Smith B. The dental relevance of gastro-oesophageal reflux. Part 2. Dent Update 1996;23(6):250-3.

Bassiouny MA, Kuroda S, Yang J. Topographic and radiographic profile assessment of dental erosion. Part I: Effect of acidulated carbonated beverages on human dentition. Gen Dent 2007;55(4):297-305.

Benages A, Munoz JV, Sanchiz V, Mora F, Minguez M. Dental erosion as extraoesophageal manifestation of gastro-oesophageal reflux. Gut 2006;55:1050-1. DOI: 10.1136/gut. 2006.093377.

Bevilácqua FM, Zezell DM, Magnani R, da Ana PA, Eduardo CP. Fluoride uptake and acid resistance of enamel irradiated with Er:YAG laser. Lasers Med Sci 2008;23:1417.

Bidwell HL, Dent CD, Sharp JG. Bulimia-induced dental erosion in a male patient. Quintessence Int 1999;30(2):135-8.

Boari HGD, Zezell DM. Nd:YAG laser in caries prevention: clinical trial. J Dent Res $2001 ; 80(4): 1068$.

Cantarou A, Schepartz B. Bioquímica. Trad. de Alberto Calheiros. Rio de Janeiro: Atheneu; 1968. p. 183-5.

Carretero JLC, Calleja JMLA. Gastroesophageal reflux diagnosed by occlusal splint tintion. Med Oral Patol Oral Cir Bucal 2006; 11:E26-28. 
Castellan CS, Luiz AC, Bezinelli LM, Lopes RMG, Mendes FM, Eduardo CP, et al. In vitro evaluation of enamel demineralization after Er:YAG and Nd:YAG laser irradiation on primary teeth. Photomed Laser Surg 2007;25(2):21-6.

Cecchini RCM. Estudo in vitro do efeito da radiação do laser de Er: YAG em esmalte dental: análise de espectrometria de emissão atômica e microscopia eletrônica de varredura [Tese de Doutorado]. São Paulo: Faculdade de Odontologia da USP; 2001.

Christensen GJ. Oral care for patients with bulimia. J Am Dent Assoc 2002;133(12):1689-91.

Dugmore CR, Rock WP. A multifactorial analysis of factors associated with dental erosion. Br Dent J 2004;196(5):283-6.

Ferreira JM, Palamara J, Phakey PP, Rachinger WA, Orams HJ. Effects of continuous-wave $\mathrm{CO}_{2}$ laser on the ultrastructure of human dental enamel. Arch Oral Biol 1989;34:551-62.

Ganss C, Klimek J, Brune V, Schurmann A. Effects of two fluoridation measures on erosion progression in human enamel and dentine in situ. Caries Res 2004;38:561-6.

Ganss C, Klimek J, Schaffer U, Spall T. Effectiveness of two fluoridation measures on erosion progression in human enamel and dentine in vitro. Caries Res 2001;35:325-30.

Ganss C, Schlueter N, Hardt M, Schattenberg P, Klimek J. Effect of fluoride compounds on enamel erosion in vitro: a comparison of amine, sodium and stannous fluoride. Caries Res 2008;42:2-7.

Gilchrist F, Santini A, Harley K, Deery C. The use of micro-Raman spectroscopy to differentiate between sound and eroded primary enamel. Int J Paediatr Dent 2007;17(4):274-80.

Goodman BD, Kaufman HW. Effects of an argon laser on the crystalline properties and rate of dissolution in acid of tooth enamel in the presence of sodium fluoride. $J$ Dent Res 1977;1201-7.

Graubart J, Gedalia I, Pisanti S. Effects of fluoride pretreatment in vitro on human teeth exposed to citrus juice. J Dent Res 1972;51:1677-80. 
Gregory-Head BL, Curtis DA, Kim L, Cello J. Evaluation of dental erosion in patients with gastroesophageal reflux disease. J Prosthet Dent 2000;83(6):675-80.

Hannig C, Hamkens A, Becker K, Attin R, Attin T. Erosive effects of different acids on bovine enamel: release of calcium and phosphate in vitro. Arch Oral Biol 2005;50:541-52.

Holbrook WP, Armadottir B, Kay EJ. Prevention. Part 3: Prevention of tooth wear. Br Dent J 2003;195:75-81.

Hooper SM, Hughes JA, Newcombe RG, Addy M, West NX. A methodology for testing the erosive potential of sports drinks. J Dent 2005;33:343-8.

Hooper SM, Newcombe Rg, Faller R, Eversole S, Addy M, West NX. The protective effects of toothpaste against erosion by orange juice: studies in situ and in vitro. $\mathrm{J}$ Dent 2007;35:476-81.

Hossain MM, Hossain M, Kimura Y, Kinoshita J, Yamada Y, Matsumoto K. Acquired acid resistance of enamel and dentin by $\mathrm{CO}_{2}$ laser irradiation with sodium fluoride solution. J Clin Laser Med Surg 2002;20:77-82.

Hove LH, Holme B, Ogaard B, Willumsent T, Tveit AB. The protective effect of $\mathrm{TiF}_{4}$, $\mathrm{SnF}_{2}$ and $\mathrm{NaF}$ on erosion of enamel by hydrochloric acid in vitro measured by white light interferometry. Caries Res 2006;40:440-3.

Hove LH, Holme B, Young A, Tveit AB. The protective effect of $\mathrm{TiF}_{4}, \mathrm{SnF}_{2}$ and $\mathrm{NaF}$ against erosion-like lesions in situ. Caries Res 2008;42:68-72.

Hughes JA, West NX, Addy M. The protective effect of fluoride treatments against enamel erosion in vitro. J Oral Rehabil 2004;31:357-63.

Hsu CY, Jordan TH, Dederich DN, Wefel JS. Effects of low-energy $\mathrm{CO}_{2}$ laser irradiation and the organic matrix on inhibition of enamel demineralization. J Dent Res 2000;79(9):1725-30.

Jaeger DHJ, Vieira AM, Ruben JL, Huysmans MCDNJM. Influence of beverage composition on the results of erosive potential measurement by different measurement techniques. Caries Res 2008;42:98-104. 
Jarvinen V, Meurman JH, Hyvarinen $\mathrm{H}$. Dental erosion and upper gastrointestinal disorders. Oral Surg Oral Med Oral Pathol 1988;65:298-303.

Jensdottir T, Arnadottir IB, Thorsdottir I, Bardow A, Gudmundsson K, Theodors A, et al. Relationship between dental erosion, soft drink consumption, and gastroesophageal reflux among Icelanders. Clin Oral Invest 2004;1-10.

Jensdottir T, Holbrook P, Nauntofte B, Buchwald C, Bardow A. Immediate erosive potential of cola drinks and orange juices. J Dent Res 2006;85(3):226-30.

Kantorowitz ZVI, Featherstone JDB, Deniel F. Caries prevention by $\mathrm{CO}_{2}$ laser treatment: Depending on the number of pulses used. J Am Dent Assoc 1998;129:585-91.

Lackey MA, Barth J. Gastroesophageal reflux disease: a dental concern. Gen Dent 2003;51(3):250-4.

Lagerweij MD, Buchalla W, Kohnke S, Becker K, Lennon AM, Attin T. Prevention of erosion and abrasion by a high fluoride concentration gel apllied at high frequencies. Caries Res 2006;40(2):148-53.

Larsen MJ. On the prevention of enamel erosion as caused by soft drinks and orange juice by means of fluoride. Caries Res 2001;35:229-34.

Larsen MJ, Nyvad B. Enamel erosion by some soft drinks and orange juices relative to their $\mathrm{pH}$, buffering effect and contents of calcium phosphate. Caries Res $1999 ; 33(1): 81-7$.

Larsen MJ, Richards A. Fluoride is unable to reduce dental erosion from soft drinks. Caries Res 2002;36:75-80.

Levitch LC, Bader JD, Shugars DA, Heymann HO. Non-carious cervical lesions. J Dent 1994;22(4):195-207.

Linfante-Oliva C, López-Jornet P, Camacho-Alonso F, Esteve-Salinas J. Study of oral changes in patients with eating disorders. Int J Dent Hyg 2008;6:119-22.

Liu Y, Hsu CYS. Laser-induced compositional changes on enamel: a FT-Raman study. J Dent 2007;35(3):226-30. Epub 2006. DOI:10.1016/j.jdent.2006.08-006. 
Lussi A, Hellwig E, Zero D, Jaeggi T. Erosive tooth wear: diagnosis, risk factors and prevention. Am J Dent 2006;19(6):319-25.

Lussi A, Jaeggi T, Jaeggi-Schärer S. Prediction of the erosive potential of some beverages. Caries Res 1995;29(5):349-54.

Lussi A, Jaeggi T, Zero D. The role of diet in the aetiology of dental erosion. Caries Res 2004;38 (suppl 1):34-44.

Lussi A, Megert B, Eggenberger D, Jaeggi T. Impact of different toothpastes on the prevention of erosion. Caries Res 2008;42:62-7.

Lussi A, Portmann P, Burshop B. Erosion on abraded dental hard tissues by acid lozenges: an in situ study. Clin Oral Invest 1997;1:191-4.

Magalhães AC, Kato MT, Rios D, Wiegand A, Attin T, Buzalaf MAR. The effect of an experimental $4 \% \mathrm{TiF}_{4}$ varnish compared to $\mathrm{NaF}$ varnishes and $4 \% \mathrm{TiF}_{4}$ solution on dental erosion in vitro. Caries Res 2008a;42:269-74.

Magalhães AC, Rios D, Machado MAAM, Silva SMB, Lizarelli RFZ, Bagnato VS, et al. Effect of $\mathrm{Nd}: Y A G$ irradiation and fluoride application on dentine resistance to erosion in vitro. Photomed Laser Surg 2008b;26(6):559-63.

Magalhães AC, Stancari FH, Rios D, Buzalaf MAR. Effect of an experimental 4\% titanium tetrafluoride varnish on dental erosion by a soft drink. J Dent 2007;35:85861.

McCormack SM, Fried D, Featherstone JDB, Glena RF, Seka W. Scanning electronmicroscope observations of $\mathrm{CO}_{2}$ laser effects on dental enamel. J Dent Res 1995;74:1702-8.

Meurman JH, Harkonen M, Naveri H, Koskinen J, Torkko H, Rytomaa I, et al. Experimental sports drinks with minimal dental erosion effect. Scand J Dent Res 1990;98(1):120-8.

Meurman JH, Rytomaa I, Kari K, Laakso T, Murtomaa H. Salivary pH and glucose after consuming various beverages including sugar-containing drinks. Caries Res 1987;21:353-9. 
Meurman JH, Toskala J, Nuutinen P, Klemetti E. Oral and dental manifestations in gastroesophageal reflux disease. Oral Surg Oral Med Oral Pathol 1994;78:583-9.

Moazzez R, Anggiansah A, Bartlett DW. The association of acidic reflux above the upper oesophageal sphincter with palatal tooth wear. Caries Res 2005;39(6):475-8.

Moazzez R, Bartlett DW, Anggiansah A. Dental erosion, gastro-oesophagel reflux disease and saliva: how are they related? J Dent 2004;32:489-94.

Moazzez R, Smith BGN, Bartlett DW. Oral pH and drinking habit during ingestion of a carbonated drink in a group of adolescents with dental erosion. J Dent $2000 ; 28(6): 395-7$.

Mountcastle VB. Fisiologia médica. $13^{\mathrm{a}}$ ed. Trad. de Luiz Barreto. Rio de Janeiro: Guanabara Koogan; 1979. p. 1183-5.

Nelson DGA, Shariati M, Glena R, Shields CP, Featherstone JDB. Effect of pulsed low energy infrared laser irradiation on artificial caries-like lesion formation. Caries Res 1986;20:289-99.

Nelson DGA, Wefel JS, Jongebloed WI, Featherstone JDB. Morphology, histology and crystallography of human dental enamel treated with pulsed low-energy infrared laser radiation. Caries Res 1987;21:411-26.

Nelson DGA, Williamson BE. Low-temperature laser Raman spectroscopy of synthetic carbonated apatites and dental enamel. Aust J Chem 1982;35:715-27.

Nunn JH. Prevalence of dental erosion and the implication for oral health. Eur J Oral Sci 1996;104:156-61.

Oginni AO, Agbakwuru EA, Ndubuda DA. The prevalence of dental erosion in Nigerian patients with gastro-oesophageal refluz disease. BMC Oral Health $2005 ; 5(1): 1-6$.

Osborne-Smith KL, Burke FJT, Manchester NHFW. The aetiology of the non-carious cervical lesion. Int Dent J 1999;49(3):139-43. 
O’Sullivan EA, Curzon MEJ, Roberts GJ, Milla PJ, Stringer MD. Gastroesophageal reflux in children and its relantionship to erosion of primary and permanent teeth. Eur J Oral Sci 1998;106(3):765-9.

Pace F, Pallotta S, Tonini M, Vakil N, Porro GB. Systematic review: gastrooesophageal reflux disease and dental lesions. Aliment Pharmacol Ther 2008;27:1179-86.

Park HJ, Kwon TY, Nam SH, Kim HJ, Kim KH, Kim YJ. Changes in bovine enamel after treatment with a $30 \%$ hydrogen peroxide bleaching agent. Dent Mater $\mathrm{J}$ $2004 ; 23(4): 517-21$.

Perkins S, Wetmore ML. Acid-induced erosion of teeth. Dent Today 2001;82-7.

Rees J, Loyn T, Gilmour A. Does low acid orange juice equal low erosion? Dent Update 2006;242-4.

Robb ND, Smith BGN, Geidrys-Leeper E. The distribution of erosion in the dentitions of patients with eating disorders. Br Dent J 1995;178(5):171-5.

Robinson C, Shore R, Brooks S, Strafford S, Wood S, Kirkham J. The chemistry of enamel caries. Critical Rev Oral Biol Med 2000;11(4):481-95.

Rytömaa I, Järvinen V, Kanerva R, Heinonen OP. Bulimia and tooth erosion. Acta Odontol Scand 1998;56(1):36-40.

Sakoolnamarka R, Burrow MF, Prawer S, Tyas MJ. Raman spectroscopic study of noncarious cervical lesions. Odontology 2005;93:35-40.

Scheutzel P. Etiology of dental erosion - intrinsic factors. Eur J Oral Sci 1996;104:178-90.

Schlueter N, Ganss C, Mueller U, Klimek J. Effect of titanium tetrafluoride and sodium fluoride on erosion progression in enamel and dentine in vitro. Caries Res 2007;41:141-5.

Schroeder PL, Filler SJ, Ramirez B, Lazarchik DA, Vaezi MF, Richter JE. Dental erosion and acid reflux disease. Ann Intern Med 1995;122:809-15. 
Schulze KA, Balooch M, Balooch G, Marshall GW, Marshall SJ. Micro-Raman spectroscopic investigation of dental calcified tissues. J Biomed Mater Res 2004;69A:286-93.

Silva MAGS, Damante JH, Stipp ACM, Tolentino MM, Carlotto PR, Fleury RN. Gastroesophageal reflux disease: new oral findings. Oral Sug Oral Med Oral Pathol Oral Radiol Endod 2001;91(3):301-10.

Silverstone LM. Preventive dentistry. London: Update Books; 1978.

Sobral MAP, Luz MAAC, Gama-Teixeira A, Garone Netto N. Influência da dieta líquida ácida no desenvolvimento de erosão dental. Pesqui Odontol Bras 2000;14(4):406-10.

Sobral MAP, Lachowski KM, Rossi W, Braga SRM, Ramalho KM. Effect of Nd:YAG laser and acidulate phosphate fluoride on bovine and human enamel submitted to erosion/abrasion or erosion only: an in vitro preliminary study. Photomed Las Surg $2009 ; 27(5)$. In press.

Spigset O. Oral symptoms in bulimia nervosa - a survey of 34 cases. Acta Odontol Scand 1991;49(6):335-9.

Tagomori S, Morioka T. Combined effects of laser and fluoride on acid resistance of human dental enamel. Caries Res 1989;23:225-31.

ten Cate JM, Imfeld T. Dental erosion, summary. Eur J Oral Sci 1996;104:241-4.

Tepper SA, Zehnder M, Pajarola GF, Schmidlin PR. Increased fluoride uptake and acid resistance by $\mathrm{CO}_{2}$ laser-irradiation through topically applied fluoride on human enamel in vitro. J Dent 2004;32:635-41.

Touyz LZG. The acidity $(\mathrm{pH})$ and buffering capacity of Canadian fruit juice and dental implication. J Can Dent Assoc 1994;60(5):454-8.

Tramini P, Pelissier B, Valcarcel T, Bonnet B, Maury L. A Raman spectroscopic investigation of dentin and enamel structures modified by lactic acid. Caries Res 2000;34:233-40. 
Tsai CL, Lin YT, Huang ST, Chang HW. In vitro acid resistance of $\mathrm{CO}_{2}$ and $\mathrm{Nd}$ :YAG laser-treated human tooth enamel. Caries Res 2002;36:423-9.

Tsuda H, Arends J. Raman spectra of human dental calculus. J Dent Res 1993;72:1609-13.

Van Rijkom H, Ruben J, Vieira A, Huysmans MC, Truin GJ, Mulder J. Erosioninhibiting effect of sodium fluoride and titanium tetrafluoride treatment in vitro. Eur $\mathrm{J}$ Oral Sci 2003;111:353-7.

Van Roekel NBV. Gastroesophageal reflux disease tooth erosion, and prosthodontic rehabilitation: a clinical report. J Prosthodont 2003;12(4):255-9.

Vieira A, Jaeger DHJ, Ruben JL, Huysmans MCDNJM. Inhibition of erosive wear by fluoride varnish. Caries Res 2007;41:61-7.

Vieira A, Ruben JL, Huysmans M. Effect of titanium tetrafluoride, amine fluoride and fluoride varnish on enamel erosion in vitro. Caries Res 2005;39(5):371-9.

Vilela GG. Bioquímica. Rio de Janeiro: Guanabara Koogan; 1961. p. 383-7.

Vlacic J, Meyers IA, Walsh LJ. Laser-activated fluoride treatment of enamel as prevention against erosion. Aust Dent J 2007;52(3):175-80.

Wentrup-Byrne E, Armstrong CA, Armstrong RS, Collins BM. Fourier transform Raman microscopia mapping of the molecular components in a human tooth. $J$ Raman Spectrosc 1997;28:151-8.

West NX, Hughes JA, Addy M. The effect of $\mathrm{pH}$ on the erosion of dentine and enamel by dietary acids in vitro. J Oral Rehabil 2001;28:860-4.

Wiegand A, Attin T. Occupational dental erosion from exposure to acids - a review. Occup Med 2007; 57(3):169-76. DOI: 10.1093/occmed/kq 1163.

Willumsen J, Ogaard B, Hansen BF, Rolla G. Effect from pretreatment of stannous fluoride versus sodium fluoride on enamel exposed to $0.1 \mathrm{M}$ or $0.01 \mathrm{M}$ hydrochloric acid. Acta Odontol Scand 2004;(62):278-81. 
Yamada MK, Uo M, Ohkawa S, Akasaka T, Watari F. Three-dimensional topographic scanning electron microscope and Raman spectroscopic analyses of the irradiation effect on teeth by Nd:YAG, Er:YAG, and $\mathrm{CO}_{2}$ lasers. J Biomedical Mat Res 2004;71B (1):7-15.

Yamamoto $\mathrm{H}$, Ooya K. Potential of yttrium-aluminum-garnet laser in caries prevention. J Oral Pathol 1974;3:7-15.

Yamamoto H, Sato K. Prevention of dental caries by acousto-optically Q-switched Nd:YAG laser irradiation. J Dent Res 1980;59(2):137.

Yip KH, Smales RJ, Kaidonis JA. The diagnosis and control of extrinsic acid erosion of tooth substance. Gen Dent 2003;51(4):350-3.

Zero DT. Etiology of dental erosion - intrinsic factors. Eur J Oral Sci $1996 ; 104(2): 162-77$. 


\section{NIVERSIDADE DE SÄO PAILO \\ FACLIDADI DI: OBONTOLOCIA}

\section{PARECER DE APROVAÇĀO Protocolo $119 / 06$}

O Grupo de Trabalho indicado peto Comite de Ética em Pesquisa: APROVOU o protocolo de pesquisa "Comparaçăo to potencial erosivo de duas fontes ácidas sobra o ssmalte e avaliaçăo de métodos de prevençāo da erosăo dental' ${ }^{r}$, de responsabilidade da Pesquisadora Sheila Regina Maia Braga, sob orientação da Professora Doutora Maria Angela Pita Sobral.

Tendo en vista a legislaçăo vigente, devem ser encaminhados a este Comité relatórios anuais referentes ao andamento da pesquisa e ao término cópia do trabalho em "cd". Qualquer emenda do projeto original deve ser apresentada a este CEP para apreciaçăo, de forma clara e sucinta, identificando a parte do protocolo a ser modificada e suas justificativas.

Säo Paulo: 01 de agosto de 2006

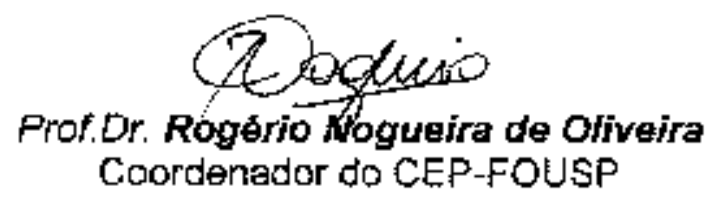


ANEXO B - Parecer do Comitê de Ética em Pesquisa (HU-USP)

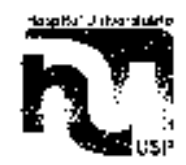

Sta Psulb, 27 de tomembra de $2(1) 6$.

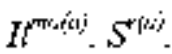

Profin. Dra. Haria Ângela Iita Sobral

Departamento de Detulisticy

Taculdade de Odoniologia

TTNVT:RSTMATY TIT SÃO PAI.IO

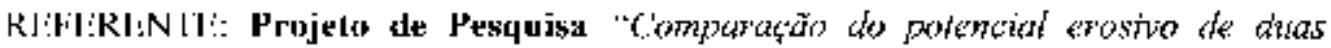

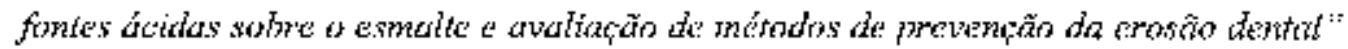
- Co-autor(es): Sheila Regina Midia Hraga - Regisiro CkP-HU/USP: 689:06 SIS.NEP CAAE: (0644.01.198.017-(k6,

Prezadu(a) Sเ:nhor(iz)

O Connitĉ de Élica em Pesquisa do l Iospital Universítáro de Ynjversidade

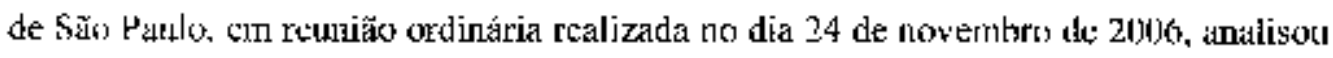
o frojeto de pesquisa atima cilado, considerando-0 como APROVADO, bcm cono, sen Termo de Consbalinnento Livre e Esclarecido.

I.crubranpos que cabe ao pesquisador elaborar e apresserlatr a esle Comitê,

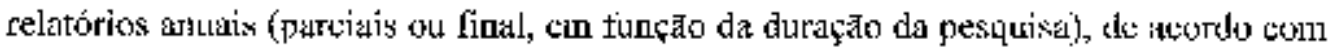
a Resoluça 196/96 du Conselho National de Siáde, item LX.2 letra c.

O prianciro relatório cstá previsto para 24 de novembro de 2907.

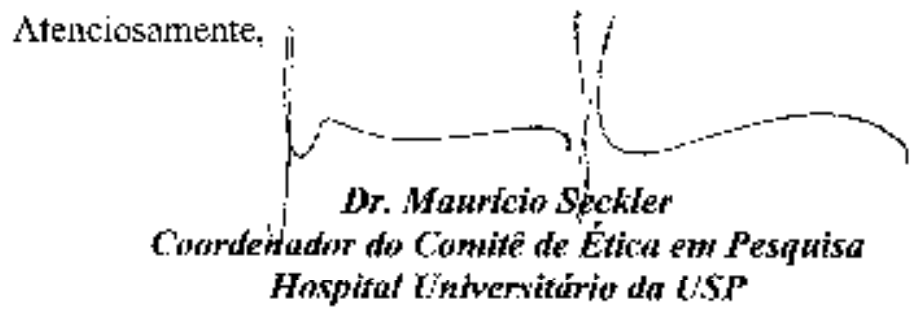

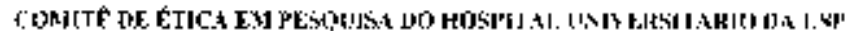

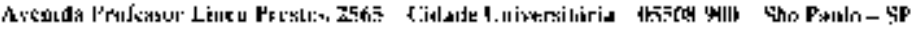

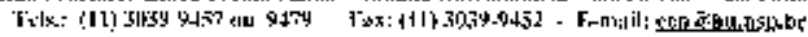


ANEXO C - Termo de consentimento livre e esclarecido

\section{TERMO DE CONSENTIMENTO LIVRE E ESCLARECIDO}

Estamos realizando uma pesquisa com título "Comparação do potencial erosivo de duas fontes ácidas sobre o esmalte e avaliação de métodos de prevenção da erosão dental", com o objetivo de verificar se o flúor e o laser, associados ou não, são eficazes na prevenção da ação do suco gástrico e de uma bebida ácida sobre os dentes.

Você está sendo convidado a participar como voluntário desta pesquisa. É muito importante que você compreenda as informações contidas neste documento.

Não haverá benefício direto para o voluntário, mas esta pesquisa trará maior conhecimento sobre o tema abordado.

Nós necessitamos de suco gástrico e gostaríamos que fosse doado para esta pesquisa. No exame de endoscopia o suco gástrico é normalmente aspirado e descartado, portanto, não haverá qualquer modificação no exame de endoscopia indicado por razões médicas. Não haverá nenhum risco de ordem física ou psicológica em decorrência da aspiração e coleta do suco gástrico durante o exame de endoscopia.

Os voluntários receberão respostas às suas perguntas e esclarecimentos de suas dúvidas sobre este trabalho sempre que desejarem. Os voluntários não serão identificados na publicação do trabalho, bem como ao longo do experimento.

Os voluntários têm total liberdade de retirar o seu consentimento a qualquer momento, deixando de participar do estudo sem nenhum prejuízo para o tratamento médico ao qual tem se submetido.

Consentimento pós-informação:

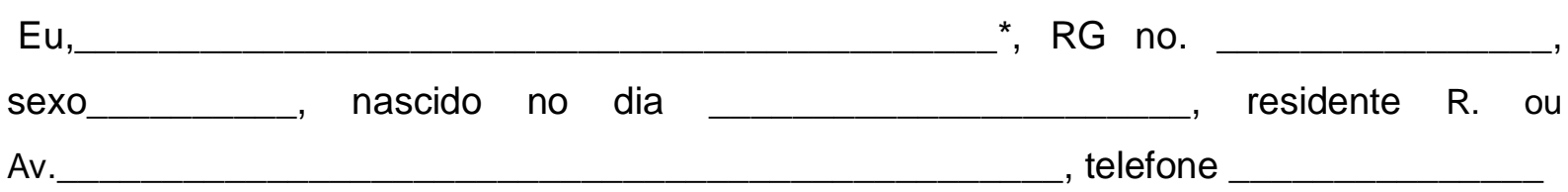

declaro que, após convenientemente esclarecido pela pesquisadora e ter entendido o que me foi explicado, consinto em participar do presente Projeto de Pesquisa. 
São Paulo, de de 2007.

Assinatura do voluntário ou responsável legal
Assinatura do pesquisador responsável

Pesquisadora Responsável: Maria Angela Pita Sobral telefone de contato: 55068390

Pesquisadora: Sheila Regina Maia Braga telefone de contato: $3231-2859$

E-mail: sheilabr@usp.br

Departamento de Dentística

Faculdade de Odontologia da USP

Av. Prof. Lineu Prestes, 2227 - Cidade Universitária

CEP:05508-900

Telefone: $3091-7843$

Comitê de Ética em Pesquisa (CEP-HU)

Endereço: Av. Prof. Lineu Prestes, 2565 - Cidade Universitária

CEP: 05508-900 - São Paulo -SP

Telefones: 3039-9457 ou 3039-9479

E-mail: cep@hu.usp.br 